Historic, archived document

Do not assume content reflects current scientific knowledge, policies, or practices. 



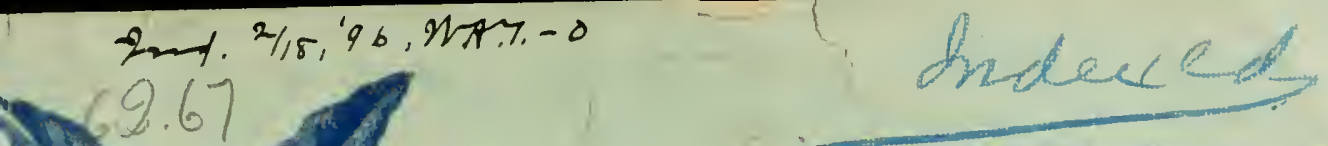

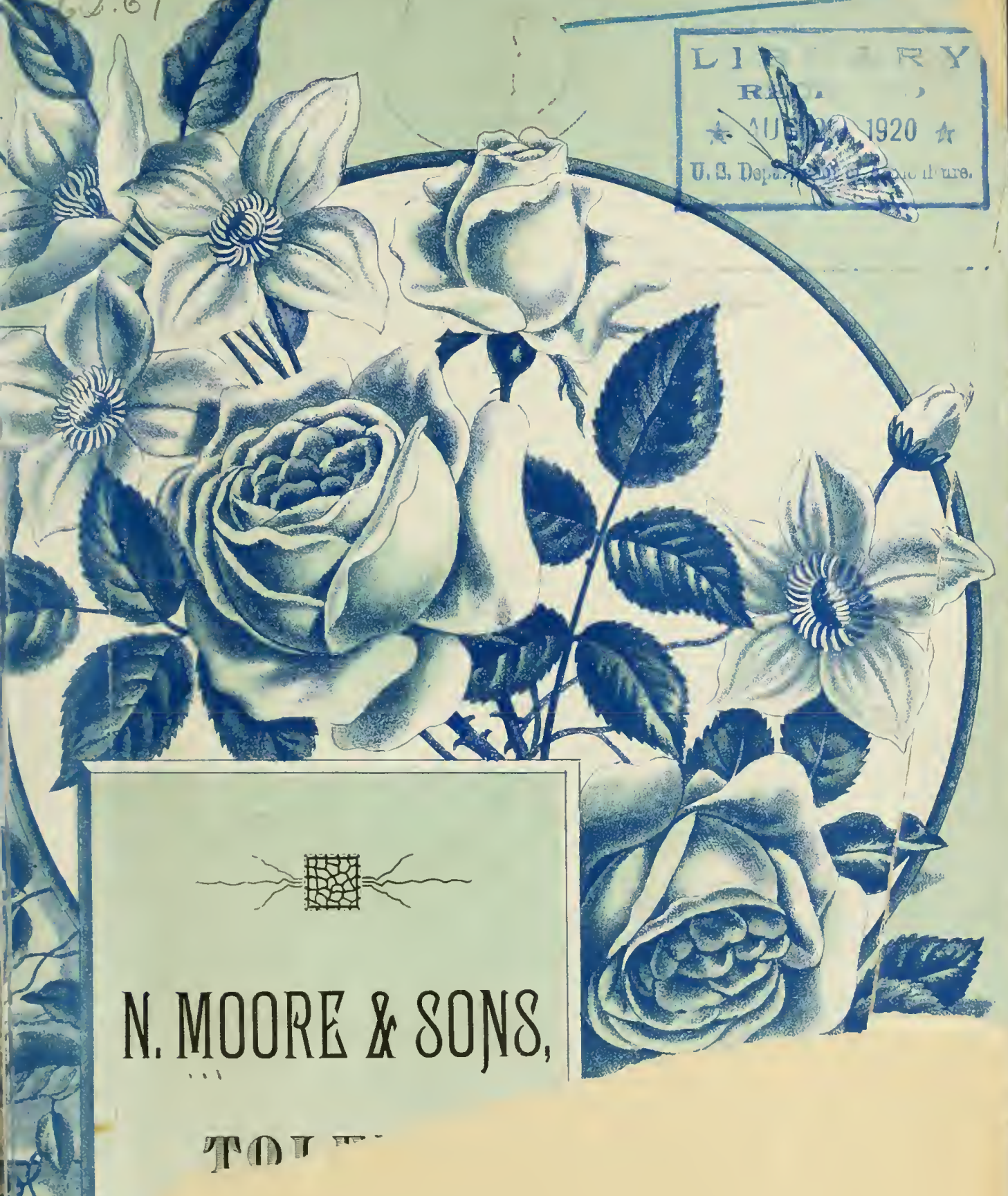





\section{Descriptive and llLustrated}

\section{CATALOGUE}

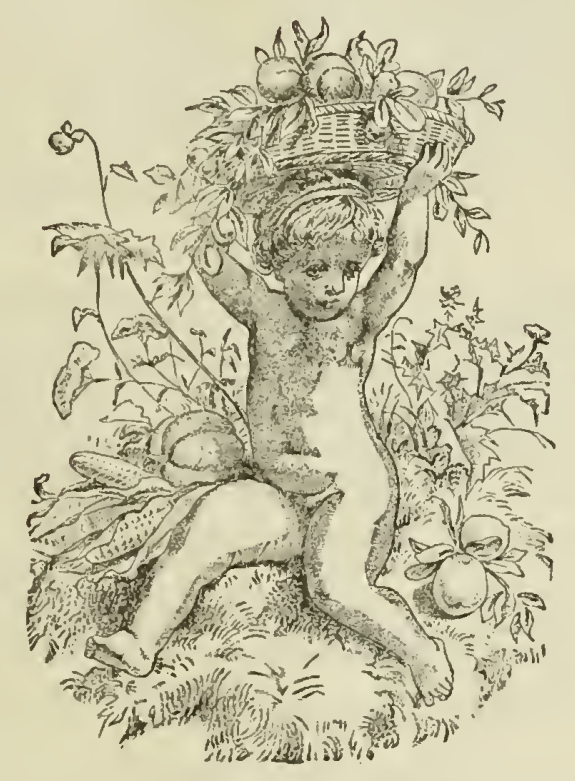

FIRUIT AND ORNAMENTAL

\section{TREES,}

SHTIBS, PIANTS, E'TO. 


\section{ÄDVICE TO CORRESPONDENTS.}

1. It is advisable to send in your orders early.

2. Write your orders plainly on a separate paper, and not in body of letter. State defiuitely varieties, age, size, and number, whether Standard ol Dwarf, and route by which jou wish the gouls shipped.

3. All orders from unknown parties should he accompanied hy cash or satisfactory reference.

4. We are in no case responsible for loss or damage to goods in transit. Our responsibility ceases on delivery to shipping ageuts.

5. If selection of varieties is left to us we will select according to our best judgment and long experience.

6. In case of any mistake on ourpart, immediate notice should he given, so that it may be rectified.

\section{REMARKS.}

To the planter or purchaser of nursery stock, at least three things are indispensable : first, varieties true to name; second, healthy, vigorous, well matured trees or plants; third, careful and judicious pecking, without which all may be lost.

We give the most careful scrutiny to the propagation of varieties, endeavoring hy all methods known to us, to protect oulselves from error or imposition, and rejecting anything of which we have reason to feel suspicious By such careful and constant watching and actention, we are warranted in offering our stocis as pure and absolutely true to name.

Our soil being of a character hest suited to produce the healthiest conditions of growth, that solid firm texture of the wood, with abundant fihrous root, so necessary to successful trausplauting, we are enahled to offer the products of our Nurseries, with entire confidence, to planters in all sections of the country.

We give to our packing and shipping careful pelsonal supervision, and to still further protect our patron, as well as ourselves, against loss iu this direction, we employ the most skilled aud competent hands to assist us,

We aim to keep fully ahreast of an enlightened and cultivated taste, in the intioluction of new and valuahle varieties of fruit, and novelties aud valuable acquisitions in ornamentals-accepting witl pleasure everything that has real merit, we shall with equal readiness discard and discountenance the sale of worthless humbugs.

By careful consideration of the wants of our trade and faithful attentiou to husiness, we hope to contiuue to merit and receive a share of the paironage of lovers and buyers of choice fruits and ornamentals.

\section{ADVICE TO PLANTERS.}

Select thrifty young trees in preference $t$ " old or very large ones; the roots are more tender and fibrous, and they hear transplanting hetter and far more apt to live; they can also be more easily trimmed and shaped to auy desired form, and in the course of a few $y$ ears will usually outstrip the older ones in grow th.

\section{THE SOIL.}

A rich loam is the hest for fruit, made sufficiently dry by artificial draining, if necessary, but all soils may be made available by judicious ti*aturent.

\section{PREPARATION FOR PLANTING.}

Plow and suhsoil repeatedly, so as to thoronghly pulverise to a depth of 12 to 18 inches. When plating upon the lawn or grass plots, rellove tle sod for' a dianeter of 4 or 5 feet, aud keep this spact well worked and free fiom weeds. Dig the hole deeper aud larger than is necessary to admit all the roots in their natural position, keeping the surface and subsoil separate. Cut off hroken and biuised roots and shorten the tops to a half a dnzen good huds, except for Fall planting, when it is better to defer top pruning until the following spring. If not prepared to plant when your" stock arrives, " heel in " ly digging a trench deep enougly to admit all the loots and setting the trees thereiu as tley can stand, carefully packing the earth about the loots, taking up when lequired. Never leave the roots exposed to the sun and air, and "puddle" before planting.

\section{PLANTING.}

Fill up the hole with surface soil, so that the tree will stand ahout as it did when in the nursery after the earth has settled, except Dwarf Pears, which should be planted deep enough to cover the quince stock upon which the $\mathrm{y}$ are hudded two or three inches. Work the soil thoroughly among the loots, and when well covered tramp firmly. Set the tree firm as a post, but leave the surface filling (of poorer soil) light and loose. No staking will be required except with very tall trees. Never let mannre come in contact with the roots. 


\section{MULCHING.}

A corering of coarse manure, straw, marsh has, or loose chip dirt, during the first season, win effectually prevent injury from drought, aud is a benefit at all times.

\section{DAMAGED TREES.}

If stock is frozen when received, place the packaje in a cellar and entirely bury in sand until the frost is removed. If dried from long exposure lury in the ground or keep in water until the shriveled appearacce disappears.

\section{HOW TO WINTER TREES PROCURED IN THE FALL.}

The practice of procuring supplies nf trees in the Fall is hecoming more and more general as each season demonntrates its risdom. To insure success you have onls to gtt the trees before fieezing neather, aud burs them in the following manner: Clionse a diy spot where uo water will stand during the winter, witl no grass near it to invite nijee. Dig a trench, throwing out enough dirt to adnit one layer of ruots below thas surface, and place the vrees in it, inclined to an angle of 45 degrees or more. Widen the tremch, throwing the soil antong the roots in position; place auother layer in the trench, reclining the tops on the others, and so on until all are in the trench ; then finisl by throwing up mole soil unth the tops of the trees are jlearls or quite covered. It is also well to bank up the earth around the sides to insure more thorough protection. "The exposed tops should then lie covered with fine hougles, which insure's them again-t any possibility of injury. Care should he taken t's fill solid all the interstices among the roots. In the spriug the ronts will be found to have formed the granulatinn necessary to the production of new sponginles, and when planted at the proper time will start to inmediate growth.

If tha trees are frozen when received, they should he hured immediately in the earth, tops and all, and allowed to thaw in this couditon.

\section{PLANT YOUNG TREES.}

We cannot too strongly recommend to our custnmers the procuring of young trees, especially for orchard planting. instead of selecting the largest that can be had, to secure mure inmediate effect. They can be taken up with more perfect roots, and will become sooner established in a new loeation. The can also be more readily trained to any desired slrapm. The largest umd must successful planters iuvariably select young, thrifty trees as the surest in the end to give thorough satisfaction.

For small grounds, or street planting, when it is necessary to make a show as soon as possible, large trees are often desurable, and when handled with eare should not fail to do well. but with the general plauter the average of los: will be much less, and both time aud nouey will be saved if young tree's are selected to commence with.

\section{DISTANCES FOR PLANTING.}

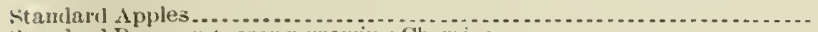

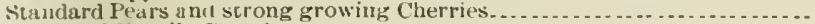
Uuke aud Morello Cherries

standaril Pluns, Apricols, Peaclies, Sectarines..............................

Dwarf Pears

DwarlP Aplyles.

30 feet apart each was.

20 " " " "

18 "

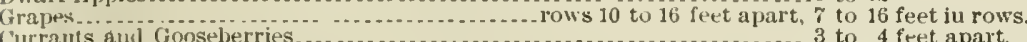

Currants ant Gonseberries.................................... 3 to 4 firet apart.

Raspberries and Blackberries............................................. 3 to 4 by 5 to 7 leet apart.

strawberries, for field culture............................................... 1 to $11 / 2$ by 3 to $31 / 2 \mathrm{ft}$. a part. Strawlerries, for garden culcure ................ i to 2 feet a part.

Note. $-A$ most excellent way in planting an apple orchard 31 ) feet apart is to ylant peaches in between. BF the tinte the apples require the ground the peaches will have passed therr prime and can be removed.

\section{NUMBER OF TREES TO AN ACRE.}

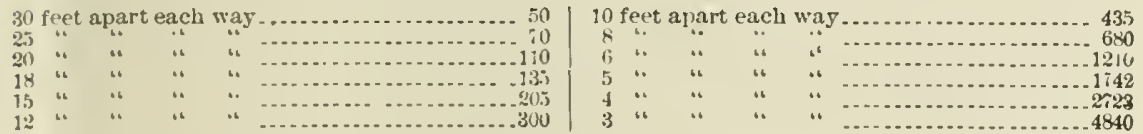

Rule.-IIultiply the distance in feet between the rows by the distance the plants are apart in the rows and the product will by the In umber of square feet tor eich plaut or lill ; which, divided into the number of feet in an acre $(43,560)$, will give the number of trees to an acre. 


\section{FRUIT DEPARTMENT.}

\section{APPLES.}

The first fruit, both in importance and general culture, is the Apple. Its period, unlike that of other fruits, extends uearly or quite through the rear. By planting judieious selections of Summer, Autumm, and Winter sorts, a constant suecession can be easily obtained of this indispeusable fruit for family use.

There is no farm crop which, on the average, will produce one-fourth as much income per acre as will a good apple orchard.

As fruit has become cheaper on aceount of the increased supply, a large and constantly increasing Europeau export has sprung up which afforls highly remunerative prices for the best selected specimens of our orchards, while the process of "Evaporatiou" of fruit has become a recognized auxiliary to the horticulture of the land. With the immense consumption by this process of evaporation, it may be doubted if apple oreharding. will ever in any season be less than highly remunerative. All the surplus of orchards, all "wind-falls" and defeetive specimens can at once be gathered and sold at a fair priee to the evaporating establishments which now exist in almost erery towu in all fruit growing sections.

If apples are plinted at the rate of fifty trees per aere, rows of peach trees ean be planted between the apples, whieh, growing more quiekly than the apple trees, soon protect them from the winds, and thus are a great benefit to them. After eight or ten years of productiveness, as the space is needed for apples, the peach trees may be removed, leaving the orcliard better for the protection, and at the same time having yielded the planter a large return for his trouble.

\section{DWARF APPLES.}

The planting of Dwarf $\Lambda$ pples hus been attended with gratifying sncecss, Almost all sorts succeed equally well when workerl upon Paradise or Doncin stock; the former producing a very small tree or shrub; the latter a tree of considerable size, reaching sonetimes to 10 or 12 fcet in height. These commence bearing fruit the second year after planting, and being as healthy as standard trees and productive are a great ornament and satisfaction. They shonld be planted from six to eight fect apart, and will produce fruit witlout the delay attending Standards. Being trained low, they are valuable for the West. Taking up but little room, they are especially adapted to village gardens of small extent, giving the owners a constant and sure supply of choice fruits, far superior to any which cau be bought iu uarket.

\section{VARIETIES OF SPECIAL MERIT.}

Great interest is now manifested in what are known as Russian and "Iron Clad Apples"-varietics sufficiently harly to stand the extreme climate of the North and North-west and yet possessing the merits in quality and size of the standard sorts of a more temperate regiou. So great has been the development in this direction, and so numerous and valuable have the kinds become that the complaint is no longer valid that good fruit cannot be produced in the far North or North-west. We mention as among the best and most prominent sorts, Duchess of Oldenburg, Tetofsky, Hats, Pewaukee, Wealthy, Walbridge, Alexander, Mamn, McIntosh, McMahon's White, Rubicon, Red Beitigheimer, New Brunswick, and Tellow Trmsparent.

\section{SUMMER.}

American Summer Pearmain-Nedium, obloug; striped and dotted with red ; tender, juicy and rich; good bearer. September.

Astrachan Red-Large, roundish, nearly covered with deep crimson, orerspread with a thiek bloom; juicy, rich, acid, beautiful; a good bearer. August.

Benoni-Medium size, ncarly round; deep red, with rich tlavor. August.

Benninger-Originated near Slatington, Pa. Large, romdish, slighlity comicar and striped, sunnyside nearly covered with purplish red. Flesh yellow and tender, mild, sub-acid, thavor delicious. Tree a strong upright grower and an annul bearer. Ripens in July and Angust.

Carolina Red June-(Red June)-Medium size, red; flesh white, tender, juic:; subacid; an abuudant bearer. June. 
Early Harvest-Medium si\%e, round, straw color ; tender, sub-acid and fine; proluctive. August.

Early Strawberry-Medium : roundish ; handsotnely striped with red ; excellent ; pro ductive. Auerust.

Early Ripe-1 large yollow apple, ripening with or immediately after the Early IIr vest: a populitr markict fruit. July.

Golden Sweet-Iarge, pile ycllow, very sweet and good ; good bearer. August.

Jefferis-liather large, romulish ; yollow, skin striped with loel ; very rieh, tencis and

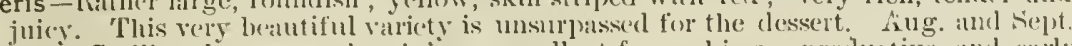

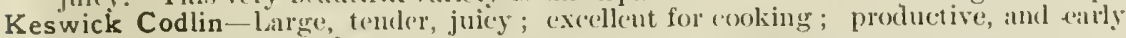
in baling. July and Iugust.

Primate-Ahove medium, straw color, tinged with blush; tender, juicy and sul)-acid abmolint bearer. Sugust and September.

Sweet Bough-1.arge, pile greenish yellow; tencler and swert; good bearer. August.

Summer Queen-Irelium to large; yellow, streaked with red; flesh tender, witl an acid, aromatic flaror. July and lingust.

Sops of Wine-Merlium size, leed; flesh white, often stainexl mild and pleasant; productive. August and september.

Tetofsky- I Rusiam apple, protitable for matkat growing ; beats extremely early, usnally the second your after transplanting, and bears every year ; hardy as a ('ab); fruit goxl size, yellow, beantifully striped with red ; juicy, pleasant, acid, aromatic. July and I Inirust.

Western Beauty-(summer Rrmbn)-Large to very large; skin pale yellow, stripul and splashed with red ; thesle light yollow, tender, juicy and melting; flavor tirst rate. Iugust and sicptember.

Williams' Favorite-Ibuve unelium si\%e; de(ep) red; mild and agrerable; gool bearer. July" and Alugust.

\section{AUTUMN.}

Autumn Strawberry-Medium streaked; tender, juicy, fine; ponductive, and very desirable. Neptember and () ('tober.

Colvert-A large; rounclish, strijecl apple; flesh whitish, juicy, sub-alcill ; valuable for market. O(tober and Nor(mb)

Chenango Strawberry-(Sherwood's Firorite)-Color whitisl,, sharled, splashed and mottled with light and dark erimson; flesh white, tender and juicy. Sept. and Oet.

Duchess of Oldenburg-Russiun, medium to laroge size ; skin yellow, streaked with lod, and somewliat blushed, sometimes witl a faint blue bloon ; flesh juiey ancl good, with a rich, smb-areit Havor; proluctive. S'ptember.

Fall Pippin-Very large, yellow ; tender, juicy and rich ; fine in all loculities. October to lecember.

Fall Jennetting-Laro, rremish ycllow, with a faint blush; flesh yellow, juicy and

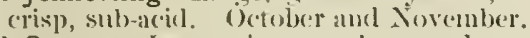

Fall Orange-Iarge size, nctrly round; yellow, sometines a little dull red; rather acid ; excellent for eooking; a very early and abundant learer. November.

Gravenstein-Large, striped aud beatiful; tender, juicy and high flavored; proluctive. Septemiber and Oetober.

Haas-(Gros Pommier, Fall Queen)-Medium to large, slightly conieal and somewlut ribbed; pale greenish yellow, shated and striped with recl; flesh fine white, sometimes statined, tender, juirey, sub-icid, gool. O(tober and Yovember.

Jersey Sweet-Ifrelimm, striperl red and green ; very rich, sweet and pleasant ; grod bearer. Septrmber and October.

Lady Henniker-Fruit very linge; roundish, witl blunt angles on the sides; skin yellow on the shady side, with faint blush of red on the side next the sun; fiesh tender, well thavored, aud with a pleasant perfume. Valuable for cooking, alwo as a dessert apple. Tree a fiee grower, very healthy, and a great bearer. Oct. and Now.

Lowell or Orange-Ialcre, roundish, slightly conical, grern, becoming vich yellow; surface oily, flesh yellowish white, sub-acid, excellent; good bealrer. S(p)t. and Oct.

Maden's Blush-Rather large, oblate, smooth, regular, with a fine, evenly shaded, led eleck or blush on a clear, pale yollow ground, thesh white, tender, sprightly, with a plensint, sub-incid 1lavor ; bears larare crops. September and October.

Munson Sweet-Large, pale yellow, with red check; teuler, rich and rool; fine: bearer. Octoluer to Jimuiny.

Pumpkin Sweet-(Lyman's)- Fery linge, roundish; skin smootlı, pille green, beronling yellow ncxt to the sun; flesh white, swect, rich and tender; valuable for baking. sieptember to December.

Porter-liather large, legular, oblong, taporing to the ege; skin bright yelluw, sonuetimes a dull blusli in the san ; Hesh tender, rich, sub-aciel ; Havor tume: fatir and pro. ductive. Nove(1uber. 
Rambo-Medium, yellowish, streaked with dull red and somewhat dotted ; mild, tender, good and productive. Oetober to Iecember.

St. Lawrence-Large, yellowish, streaked and splashed with carmine; flesh white, lightly stained, crisp, juicy, teuder and vinous; tree hardy and productire. September and Octoher.

Twenty Ounce (Cayuga Red Streak)-Very large, nearly round; Fellow, striped with red; quality good; good bearer; popular as a market variety. Nov. and Dec.

\section{WINTER.}

American Golden Russet (Bullock's Pippin, Sheep Nose)-Nedium or suall, roundish ovate; clear golden russet; very tender, juicy, rich ; more resembles in texture a buttery pear than an apple; good bearer. November to January.

Bailey's Sweet-Fruit large, round, mottled and striped deep red; flesh yellow and tender, with a mild, rieh, sweet flavor. October.

Baldwin-Large, roundish ; deep bright red; juicy, crisp, sub-atcid, good flavor ; very productive of fair, handsome fruit ; one of the best and most popular Winter apples. January to April.

Ben Davis (New York Pippin, Kentucky Streak, \&c.)-Large, handsome, striped, and of good quality ; productive ; a late keeper ; highly esteemed in the West and Southwest. December to March.

Canada Reinette-Extra large size; color light greenish yellow, with frequently a faint blush on the side exposed to the sun; many small, dark specks suffused with light green beneath the skiu; flesh white, juicy, crisp, sub-acid. December to Mar.

Cranberry Pippin-A strikingly beautiful apple, and excellent for cooking; smooth, light yellow, with bright searlet cheek; juicy, sub-acid. November to Februinry.

Cooper's Market-Dedium size ; conical ; shaded and striped with red on yellow ; flesh white and tender, with a brisk, sub-aeid flavor; hardy and productive. December to May.

Clermont-New, and said to resemble in appearance the Yellow Newtown Pippin; fruit medium to large, somewhat irregular; skin smootlı, except where russet prevails; rich orange yellow when ripe; flesh firm, ricl yellow, fine grained, mild sub-acid, rich and very good. Febrtary to March.

English Russet-Fruit medium size, very regular, slightly conieal; pale greenish yellow, about two-thirds covered with russet ; flesh sellowish white, firm and crisp, with pleasant, slightly sub-acid, flavor. January to Nlay.

Ewalt (Bullock's Pippin)-A fine, showy apple ; very large, roundish, slightly conieal ; bright yellow, shaded with crimson ou the sumny side; flesh white, tender, brisk sub-acid. November to March.

Fameuse (Snow apple)-Iledium size, roundish, very handsome; deep erimson; flesh snowy white, tender, juicy, bigh flavored and delicious. Tree vigorous, productive and very hardy. November to February.

Fallawater (Tulpehoeken, Pound, $\mathrm{dc}$.) - $\mathrm{A}$ very large, dull red apple, of good quality ; productive. November to February.

Grimes' Golden (Grimes' Golden Pippin)-An apple of the highest quality, equal to the best Newtown; medium to large size; yellow; productive; grown in southern Ohio. January to April.

Green Sweet-Medium size; skin green, somewhat dotted ; juicy and very sweet ; one of the best winter sweet apples. December to April.

Hrbbardston Nonsuch-Large, striped yellow aud red; tender, juicy and fine. Strong, good bearer. November to May.

Jonathan-Fruit medium or small, roundish ; skin yellow, nearly covered with dark or lively red; fine grained, very tender and finely flavored. November to April.

Krauser-A fine, medium size, yellow apple ; originated iu Berks County, Pa.; popular in its native locality on aceount of its haudsome appearance and good keeping qualities. December to A pril.

King (Tompkins County)-Large and handsome; strijed red and ycllow ; productive. One of the best. Norember to May.

Lady Apple-A beantiful little dessert fruit; flat, pale yellow, with a deep red cheek; juicy, rich and pleasant. November to IIay.

Ladies' Sweet $-\Lambda$ large, handsome, red apple; juiey, sweet and goorl. Dec, to MLay.

Monmouth Pippin (Red Creck Pippin) - Large, greenish yellow, with a fine red cheek; juiey, tender and good; productive. March to April.

Newtown Pippin - One of the very best apples, of high quality. Very juicy, crisp, and delicious tlavor; requires higls culture for the best fruit; fine liceper; Dec. to May.

Northern Spy-Large, roundish, slightly conical, somewhat ribbed ; striped, with the sumny side nearly covered with purphish red. Flesh white and tender, with il nild sub-acid, rich and delicious flavor. The tree should be kept open by pruning, so as to admit the air and liglit freely. January to June. 
Nickajack-I linge, roundish, striped apple of fail quality ; very harly and produetive; popular in the Sonth. December to 1 pril.

$\checkmark$ Peck's Pleasant-l Large, palle yellow ; very tender and rich, with a Newtown Pippin tlivor. line bearer. November to Mirch.

Pewaukee- $\Lambda$ scedling from Duehess of Oldenburg. Fruit medium to large, obovate, wavel; surface bright yellow, partially eovered with (lull rerl, striped and splashed, covered witl a gray bloom and overspread with whitish dots; llesh yellowish white, breaking juicy; flavor, sub-aeil, rich, aromatir, spicy, something like Jonathan ; (puility good to best. Jamuary to June.

Pomme Grise- $\Lambda$ rath(r small and beautiful gray russet apple, with a slight blush next the sun; flesh tender and high tlavored. December to Ipril.

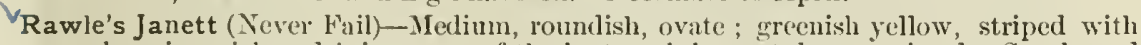
red ; crisp, rich and juicy; one of the best and longest keepers in the South and Nouthwest. February to A pril.

Rome Beauty-Large, yellow, slraded with bright red; flesh yellowish, tender, juicy, sub-acid. November to February.

Ribston Pippin-Fruit ntedium to large, splashed and inixed clull red on yellow, with slight russet; flesh yellow, erisp and juiey, with aeid, aromatic flavor ; adapted to Northern localities. October to January.

Red Canada (Old Nonsuch of Mass., Steele's Red Winter)-Medinm, oblate, red ; tender, crisp, rich sub-aeid, refreshing and delicious; productive. Jan. to May.

"Rhode Island Greening-Iarge, greenish yellow; tender, juicy and rich, with rather an acid tlavor; an abundant bearer. December to $\Lambda$ prîl.

Russet, Roxbury or Boston-Medium to large ; greenish or yellow russet ; crisp, good sub-acid flavor; productive. Very popular on account of its long keeping. January to June.

Salome-Tree a strong grower ; equals Wealthy in lurdiness; holds its fruit firmly, even against strong wind storms; an early and annual bearer, althougl a heavier crop on alternate years; fruit of medium and uniform si\%e: quality very gool, which it rotains even into summor; keeps well with ordinary care until July, and has been kept in excellent conclition until Oetober.

Seek-no-Further (Westfield)-Nedium to large; slightly russeted, with dull red stripes; tender, rich, spiey and fine. Goorl bearer. November to February.

Smith's Cider-A landsome fruit, large, oblong, somewhat flattened; skin yellow, elranging tored; flesh tender, juicy, (risp), with pleasant sub-acid flavor. Dec to Mar.

'Smokehouse-Large, yollow, shaded with bright ret ; flesh firm, (risp, juicy and finc tliv vored. October to November.

Spitzenberg, Esopus-Medium to large; deep red ; Hesh yellow, crisp, sub-acid, high Hivored. Bears and grows well transplanted in rich soil. November to April.

Sutton Beauty-Fruit medinm or alove, roundish, oblate, conic; waxen yellow, sharled, mottled and obscurely striped with fine crimson; flesh whitish, ('risp, tender, juicy ; sprightly sub-areid. Nosember to February.

Swaar-Large, pale lenon yellow, with dark dots ; tencler, with a mild, rich, agreable Hivor; one of the best. November to Min.

Tallman Sweeting-Medium, pale yellow, slightly tinged with red ; firm, rich, and very sweet; the most viluable biking apple; productive. Novenber to April.

Tewkesbury Winter Blush-Small, yellow, with red (heek; Hesh firm, juicy, and fine 1lavored; keeps until late in spring. Jammry to July.

Vandevere-Medium; yellow ground; flesh light yellow, rich, sub-acid] flavor ; early bearer. December to February.

Wagener-Medium to large; deep red in the smo; flesh firm, sub-ilcid and excellent ; v'ry productive ; bears vory young. December to Mlay.

Western Beauty-Fruit rounclish oblate, conical, gre(nish yellow, nearly covered with pale dull red, striped with darker shade; flesh gre(nish white, not firm, tender, mild sub-icicl, good. Nov'mber to F'cbruary.

Willow Twig-Large, roundish, greenish yellow, striped with dull red : flesh firm. rather tough; early bourer, and considered valuable in the South and West, where it is popular ; protitable as a late kieeper. April to Mlay.

Winesap-Medium, dark red; sub-acid, excellent; abundimt bearer. A favorite nurket variety in the Test. December to llay.

Yellow Bellflower-Large, ycllow, with pale blush ; very tender, juicy, sub-aciu ; in use all IVinter. November to April.

York Imperial-Medim, ollate; white, shaded with erimson. Flesh firm, ('risp, juicy and snb-acid. A grood bealer amel kecuer; one of the best winter apples. 1)ece to Ferli. 


\section{VARIETIES OF SPECIAL MERIT.}

'Antonovka-Russian. Tree perfectly hardr, a true "Iron Cladl." Fruit large, resembling Grines' Golden, only more oblong, and, when ripe, hats a light golden color. In season during February and Narch.

Arnold's Beauty-Seedling of Northern Spy, crossed with Wagner and Spitzenberg. Tree hardy, an abyndant bearer; briglit yellow, with red; Hesl firm, juicy, rich aromatic. January to May,

Alexander (Emperor)-Large, deep red or crimson ; thesh yellowish white, crisp, tender with pleasant flavor. Very liardy. October.

Aucubafolia-I new apple of the Russian class. Tree very hardy ; an early and abundant bearer, witl distinctly variegated leaves, very ornamental. Fruit good size, roundisl1; slightly conical; striped, with the side nearly covered with red ; tlesh fine, brisk, sub-acil. Novenler and December.

Belle de Boskoop-Large size; briglit yellow, washed with light red on sunny side ; flesh crisp, firm, juicy, sprightly, sub-acid. Quality very good, a late keeper.

Bethel-Origiu, Bethel, Yermout. Esteemed for the lardiness of the tree, and good quality of the fruit ; fruit good size, roundish, oblong; yellow, ground striped witl beautiful red, and clotted with fine red and white spots ; very best quality, and valuable for the Nortl.. New. December to February.

Bottle Greening-Resembling Rhole lsland Greening, but tree a better grower and much liardier. A native of Vermont. December to Mlarch.

Clark's Orange-Originated in Pewaukee, Wis. Frnit medium to large, nearly round like an orange; skin yellow, covered partially with vermilion ancl carmine striped; very smooth and beantiful ; flesh white, juicy, sub-acid. Good for dessert or cooking. November to January.

Delaware Red-Medium to large; bright red, highly colored ; flesh fine grained ; crisp, juicy, sub-acid ; excellent. Remarkable for its long keeping qualities, and an earlyand abundant bearer.

Gideon-Raised in Minnesota from Crab seed by Mr. Gideon. An upright grower: medium to large; color yellow, with vermilion blush on sunny side. Mild acid quality, very good.

Gano-Origiuated in Missouri. Form couical, good size and smooth ; deep red, shated on sunny side to malogany, very attractive; flesh pale yellow, fine graiued, tender. pleasant, mild, sub-acid; is a good shipper and keeper; tree healthy, vigorous aud lardy. An annual and prolitic bearer. February to May.

Huntsman's Favorite-Large, pale yellow, with shades of red, or deep rellow in the sun ; flesh pale yellow, crisp, tender, juicy, mild, sul,-acidl. December:

Hyde's King-Large to very large; yellowish green; good quality ; a renarkable keeper. Keeps the year round.

Fourth of July-A very liardy apple; bears early ; medium size; yellow with a white bloom, striped and splashed with red. Angust and Septcmber.

Heibernal-This is a Russian variety said to be more hardy than the Duchess of Oldenburg; large size; landsomely colored with red stripes; ripeuing in late fall, but keeps till midwinter.

Hastings-Very laady ; good bearer ; fruit above medium ; skin yellow, nearly eovered with deep, rich crimson. Excelleut quality, very desirable. November to February.

Hurlbut-Fruit medium size, oblate, angular ; skin yellow with red stripes and splashed with red; flesh white, crisp, tender, juicy, subacid; quality very grood. A great bearer. October to December.

Hnmphrey-New. A seedling of the Northern Spy, which it strongly resenbles in quality and appearance, but is a much louger kceper. It origiuated in Northern New Y ork, and is very hardy. A most excelent and desirable sort. Jan to June.

Ivanhoe-Originated in Virginia, Tree, vigorous aud productive; an unusually carly bearer and long keeper ; melium sized ; light golden yellow, with a shide of blush ou sumny side. Winter.

Lawver-Large, dark red, covered with small dots; flesh white, firm, crisp, sprightly, aromatic, mild sub-acid ; a beautiful and desirable fruit. January to May.

Langford Seedling-Originated in Keut County, IId. Tree a stout grower; bears young and every year : tlesh firm, juicr, mild, sub-acid. January to Hay.

Longfield-A Russian variety imported some year's since. Tree a free, upright grower, early and abundant bearer. Iredium to large; yellowish green, thickly covered with red stripes; a decided blush ou suuny side; rich, sprightly, sub-acid ; very good. December to March.

Magog Red Streak-Origin, Vermont. Bears annually large crops ; valuable for its extreme hardiness, vigor, productiveness and long keeping; fruit inedium or nearly so ; roundish, inclining to obloug; skiil light yellow, shaded and faintly striped and splashed with light red over half the fruit ; flesh yellowish; a little coarsc, moderately juicy ; mild, sub-acidl. December to March. 
Mann-New. An upright grower, forming a round heat : fruit medium to lange. roundisli, olshte: slifi deep vellow when fully ripe, with sometimes a shade of hrownish red where exposerl ; flesh yellowish, juiey, mild, pleasint, sul-neid ; good ta very good. Will keep as long as hoxbury Russet. May to Jume.

MeIntosh Red-Origin:ted in Ontario. Tree very lardy, lone lived : good amual bearer of fair, hiublsome fruit of exedlent quality, for home or market use. Hruit above medium, loumdish, oblate ; skin whit islt yellow, verv nearly covered with dark rich rex or crimson, almost purplish in the sum. Flesh white, dine, very tender, juicy, mild, sub-acid, vely promising. Novenbler to Februity.

Missouri Pippin-Medinm to latre : pale, whitish pellow, splashed with light and dark red ; llosh whitish, (risp), moderintely juicy, sub-acid. January to I pril.

Northwestern Greening-Fruit large, greenisl yollow, and remarkible as a keejer : fruits of 1884 and 1885 exlibiter sicle by side. " rrigin uncertain.

Ustrokoff-Russian.-Trer lardy and a good grower ; fruít medium sized, conical, greenish yellow, ripening in miklwinter.

McMahon's White-Originated in Wisconsin, and hats for several seasoms endured a cold of forty degrees below zero. Fruit lirge, white, striped with pale red ; flesh white, fine grancel and tender. In scason during midwinter.

New Brunswick-New. Fruit above medimm; skin whitish vellow, covered with diurk rich crimson; Hesh very firm; an excellent culinary and nuaket fruit. Origi. nated in New linumswick. October to November.

Nodhead (Jewett's Fine lied)-A native of New l Iampshire. Tree very hardy and much prized in Northern New England. Frnit nedium, greenish white, striperl witl crintson. Fl'sh tender, jnicy, very pleasilnt ; almost white.

Peach (Irish Peacli) - Iedium sizc, round or little flattencel ; yollowish green, strealied with brownish red. Flesh white, tender and juicy. 'Tree very latrly; highly prized in extreme Norll. September'.

Plumb's Cider-An ealy bearer and very podnctive ; frnit mediun, roundish, slightly conical; skin greenish yellow, sladed and rather obsemely striped and splasher with dull red ; lleslı whitisls, tender, juicy, mild, sub-acicl. S('p). to Jan.

Red Annis-From the mpper Volga, Russin, and there highly prized and largety grown. Witl one cxception grown the fartlest nortl of any known variety. Medium sizcrl ; rerl, lighly colorerl ; fieslı white, firm in textme.

Red Beitigheimer- I rare and valuable German variety. Fruit large to very large, roundisl, inelining to conicul ; stalk short, stout, in a deej) cavit $y$, calyx elosed in a large, deep basin; skin pale, ercam colored ground, mostly covered with purplish crimson; llesh white, firm, sub-acid. witl a brisk, pleasant flavor. Trec a free grower and abundant bearer. This is one of the lingest and liandsomest apples, and wortly of extensive cultivation. S'ptember.

Rolfe-New. Originatel in Maine about the 45th degree. Fruit large, of magnifiecnt appearanee; color dark red; an abundant and ammal beaner, ant wlere known, the fruit outsells all others of its season. Qunlity prime, botlı for eating and cooking. One of the very best. November to January.

Rubicon-I new apple said to be very lardy and valuable for the North. Fruit roundish, above medim in size; yellow, mostly covered with bright rich red; 1lesl ycllowisls and tirm; juicy, brisk, sub-acid; very good. February ta Marcli.

Shiawasse Beauty- Fruit medium si\%ed, rather conicul, marbled and st riped witl red : flesl whitc, very firm, tember, juic $y$, brisk, refreshing, sub)-acid. I very beatiful and desirable apple. October to January.

Stark-Grown in Olio, and ralned as a long keeper, a profitable market fruit. liruit large, roumlish ; skin greenislı fellow, sluaded and striped with liglit and dark red nearly over the whole surface, and thickly sprinkled with fight brown dots ; flesl yellowish, moderately juicy, mild, sul)-icidl. Jammity to May.

Switzer-lussian. Tree a vigorous grower; fruit resembles Fameuse in appearance : flesh tender and juiey, with a pleasant sub-atcid tlavor; exc(ellent for' the dlessert or table lise. Late fall and carly winter.

Stump-I well tried apple, but recently introduced to the public: of good si\%e; ronndisl, conieal. Flesh, firn, crisp, juicy, tender, splightly strl)-aciul. Gre(nishyellow, sladed with red. Beantifully fair, and las commanded the very lighlust prices wherever slown. October to l)ecentber.

Titovka-kussian. Tree very laardy and productive. This is the enreatest market apple of Russia. Medinni simed, pale yellow, shaded and striperl witl clark crinvorl : ripens tlirongh atutumn

Ukrainskoe-l'ussian. Tree very landy and bears while young ; fruit in size and slrape rescmbles a Nortlern spy ; tlesh coarse, sub-axdid f finc for rooking. Keepsthrough mirlwinter. 
Utter's Large Red-Large and handsone, very uniform in size ; a profuse bearer, quality good. One of the most lardy sorts. December and January.

$W$ albridge- $\Lambda$ new early variety, very desirable for extreme cold sections, having stood minjured in Minnesota, twhere all but most hardy varieties have failed. Fruit medium size, handsone, striped with red; quality good; productive. March to June.

Wealthy -1 new variety from Minnesota; liealthy, hardy and very productive. Fruit medium, oblate, skill smooth, whitish yellow, shaded with deep red in the sun, splashed and spotted in the shade. Flesh white, tine, tender, juiey, lively, sub-aeid, very good. December to February.

Wolf River $-\Lambda$ new and beautiful fruit of the very largest size. Originated near Wolf River, Wis., and may well be elassed among the iron-chads skin greenish yellow, shaded with erimson; flesh white, juicy, tender, with a peculiar, pleasant, mild, sub-acid Havor. Tree a strong, stout grower, and a great bearer. Jan. and Feb.

Yellow Transparent (Russian Transparent) - A very carly Russian apple, of good gulality and decided merits ; size nedium; color when ripe pale yellow ; sprightly, sulbacid ; great bearer ; July.

\section{Crab Apples.}

Are quite profitable for market, eoming into bearing quite early. Some of the varieties are not only good for eulinary purposes, but are especially desirable for table use. There are several points to which we wish to call attention, and on which we base our recommendation of these hardy fruits :

1st. They can be planted on any kind of soil, and in the most exposed situations, with perfect safety.

2d. They will stand the severity of the changes of the coldest weather.

3d. They will come into bearing very early, often in the sccond year from planting, and bear every year.

4th. They are very productive, giving large crops of beautiful fruit.

5th. They are unequalled for cider or vinegar.

6th. Some of them are pre-eminently dessert fruits, being of superior quality and st rikingly landsome.

7th. They can be dried, cooked, camed or preserved with the skin on, saving a great amount of trouble.

8th. The size of the fruit varies from $1 \frac{1}{2}$ to 21 inches in diameter, being large enough to quarter and core for drying, ete.

The following are the most valuable varieties :

Excelsior-Raised from seed of Wealthy, in Minnesota. Very hardy, produet:ve, and one of the best flavored varieties; ripens in September.

Gen'l Grant-Tree a vigorous and upright grower ; fruit large, round, red to very dark red; Hesh white, tender, mild sub-acid; excellent for dessert, and one of the best Crabs introduced.' October.

Hesper Rose-A good bearcr ; fruit a little smaller than General Grant; equally gool. November to Janualy.

Hewes Virginia - Rather small, round; dull red and lotted with white; acil somewhat astringent; esteemed for cider. October.

Hyslop-Almost as large as Early Strawberry Apple; deep crimson ; very popular, on aecount of its large size, beauty and liardiness. Oetober to January.

Large Red Siberian-About an inch in diameter, grown in clusters; yellow, lively scarlet cheek; bear's young and abundantly. September to Oetober.

Lady Elgin $-\Lambda$ new and promising little apple ; fruit small, fair and handsome; a very tender, delightful fruit to eat out of hand. Octobcr.

Marengo-Fruit large; yellow, shaded with bright red; flesh white and juicy when lipe; mild sub-acid. January to May.

Martha - From Minnesota. Immenscly vigorous, hardy, productive every year. Mr. Gideon says: "For sauce it surpasses any apple we ever grew." I srreat arquisition. October.

Montreal Beauty-Fruit large; bright yellow, mostly covered and shated with rich red. Flesh yellowish, riell, firm and aeid; very good. Octoler to November.

Orion- $\Lambda$ new and very desirable Crab. Bright red; one of the best. Octoler.

Orange-An annual and abundant bearer. Fruit larger than Transcendant. Flesh firm, crisp, juicy and delicious. October to December.

Quaker Beauty-A hardy sort; bars large crops of fine fruit. December to May. 
Queen's Choice-Frnit as large as Transeendant, bright yellow, with a beantiful blush check: erows in large clusters; flesh fine-grained, juicy and good. October.

Soulard-Valuable'as a cooking apple; sour and astringent as an ("ating apple, hut has, when cooked, a tine quinere-like tlavor ; color green, beconning yellow in the spring ; lieeps well antil July; very productive. Jamary to June.

Transcendant-T'ree immensely productive, benting after second year, and producing good crops by the fourth season. Frnit from one-and-a-lall to two inches in diameter, being large enongh to quanter and cole for preserving and drying. Exeellent for since and pies, both green and dried. The best of its class for cider, being juicy mud (risp), and is also by many considered a good cating apple. Skin yellow, stripul with red. September and Oetober.

Vал Wyck Sweet-l'ruit very linge; skin yellowish white, eolored light red, and covered with bloom; flesh yellowish white; very sweet and tender; small core. ()ctolecr and Nov('mber.

Whitney's Seedling-large, averaging one and a half to two inches in dianeter; skin smootl, glossy, green, striped, splished with carmine; tlesh tiru, juicy and tlavor rery pleasinnt; ripens latter part of Ang. Tree a great bearer and very hardy; a vigurous, handsome grower, with a dirk green, glossy foliage. August.

Yellow Siberian- Nearly as large as the above; fine amber or golden yellow color. September and October.

\section{PeARs.}

The cultivation of this noble fruit is cxtending as its value is appreciated. The range of varieties is such that, like apples, they" (an be had in good eating eondition from Ingust until early Spring.

The Pear, like most things highly desirable and valuable, eannot be had without attention, labor and skill. The relative price of the Apple and Pear being about as one (1) ten, show at the sume time the superior vahe of the latter, and the greater skill required to bring it to perfectiou.

One of the most important points in the manidrenent of Pears, is to gatler them at the proper time.

Summer Pears slould be gathered at least ten days before they are ripe, and Autumn l'ears at least a fortnight. Winter varieties, if they will hing so long, may be left until the leaves begin to fall.

At the present time the demand is for choice fruit, and should have the best kind of cultivation; the fruit slould be thimed so as not to over-produce. Care should be used in sclecting for market only the best sperimens and with such eflort and system on the part of the grower, they will sield a satisfactory profit.

The P'ar succeels on most soils, lut does best on a rather heavy loam. Budded on its own stock, it makes a standard tree, and on the French or Anger's Quince, a dwarf, the former being best adapted to large permanent orchards, the latter for yords and gardens.

1)waris MUST ALWAYs be planted SLFFICIESTL IEEP to cover the junction of the l'ear and Quince two or three inches-the soil made rich and well tilled, and about onehislf of the previous Summer's growtl cut off eacl Spring. Under this treatment, Dwarf are everywhere successful. The side branches should not be removed higher than ons foot from the ground in 1)warfs, while standarls may be trimmed to the heiglin desired. 'lain in pramialal form. - lipen the fruit in the honse. Gither when, on gently lifting lle frut, the stem will readily separate from the limb. Place in a dark room until fulby matnred. Winter Pears may lang on the trees nmtil there is danger from frost, then place in a diry cellar for inaturing.

The letters "D" and "S" appenderl to the deseription of varieties, inclicute favor"1ble growtl, either as "Dwaifs" or " Stanclarl," or both. Those designated us " nod(rate growers" are usually smaller trees.

\section{SUMMER.}

Bartlett-large size, with often a beautiful blush next the sun; buttery, very juicy and high tlavored ; bears early and abundantly; very popular. 1). and s. Aug. and seept.

Bloodgood-. Medium; yellow, touclerl with russet; rieh and delicious; first quality 1). antl s. Aturinst.

Beurre Assomption-This is an "ally Frencle variety; fruit latge and trec productive. I). and s. July and Angust.

Beurre Giffard-In 'xerllent viriety; medium; greenisl yellow, red in the sun ; very carly; vory preshctive. 1). and s. Augnst. 


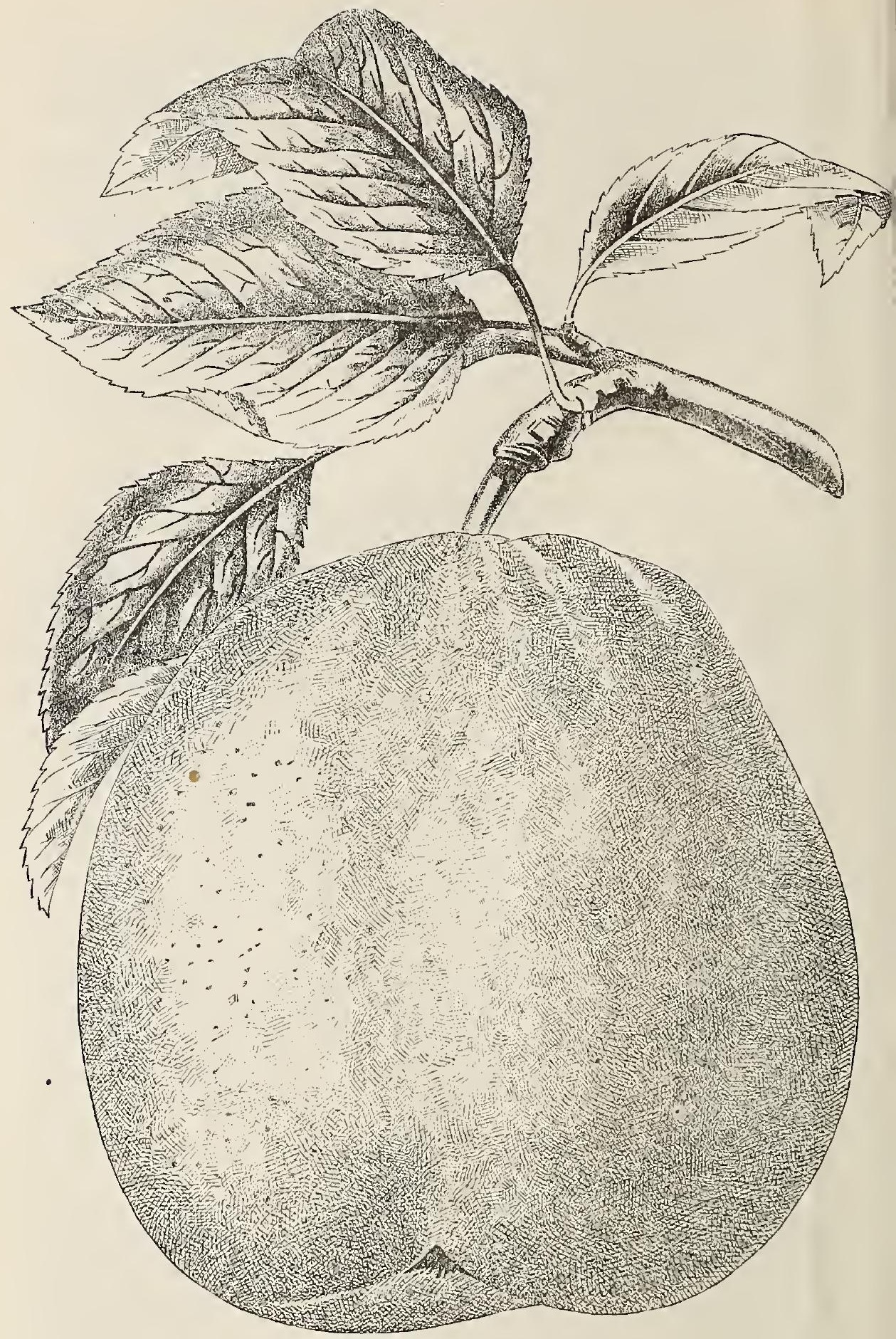

II).1110, 


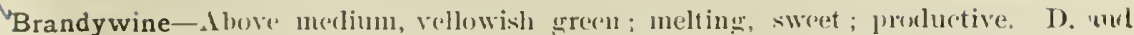
s. Allerist.

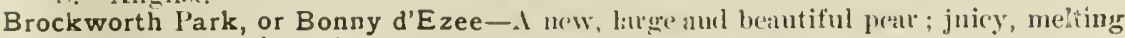
aucl ('xicellent. I). and si. sinetember.

Chambers' (Eurly Imrest or lintucky)-Originated in Maryland, and valued as at profitable eaty vaniety. Recommeniced by the lientueky lifortieultural society as the best and nost profituble nurket pear of its seasous. Fruit medium to large ; rich, grolden yellow, with rod (heck next the sum, thickly covered with gray dots. I). ant S. August.

Clapp's Favorite-Voy large; vellowish green to full vellow when ripe, marblorl witls dull rol in the sut. and coverel with small lusset spocks, vinons, utelting and rich. 1). muth si. dugust.

Dearborn's Seedling-Xrurly medinm si\%e: light pellow, sprinkled with satill dots, juicy, melting ancl fine; in abumlant bearer. 1). and s. Jugust.

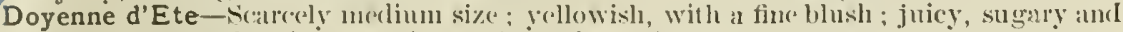
liclu; very early; finc on quinere. 1). and s. Iugust.

Kingsessing-Large, grenisl yellow; thesh juicy, buttery, with a rich perfumed thaver.

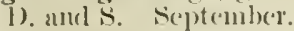

Lawson, or Comet-New; the tree is a vigurous, uplight growre; productivr, bears

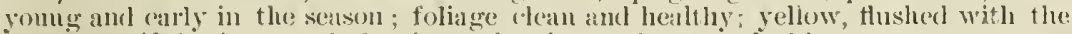

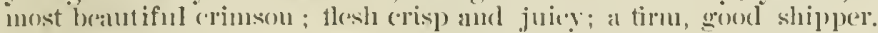

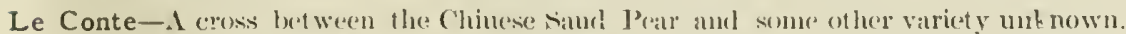

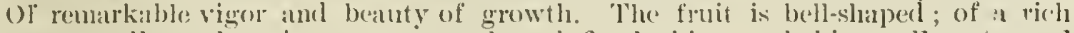

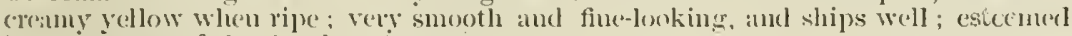
in sonie parts of the foruth. Iugust.

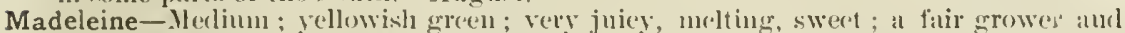
productive. 1). and si. August.

Manning's Elizabeth-sinall to medium ; bears in elusters; crintson and golel (on? (or: rery heautiful, nelting, rich, sugary, sprightly, perfumerl tlavor ; exeellent ; very poductive. One of the lesst eatly peats. Angust.

Osband's Summer-Molium, yellow, witl red clucek; half uwltiug, mild and pleasant; the thavor and excellent; produetive. D. and s. August.

Petite Marguerite-Medim size, skin greenish yellow, with brownish reel cheek, and covered with greenish clots. Flesh fine, unelting, juicy, vinons, and of first quality. Upright grower, and an carly and abundant bearer. Sinceeds admilably as a standard or dwarf. Alugust aud September.

Rostiezer-Merlimm, yellowish green, witl a bown cheek; thesh juicy, sweet and "Xx(ellent. D). aurl S. September.

Souvenir du Congres-Fruit large to very large, resembling in form the Bartloti ; skin smootlu, of a lianlsome yellow at maturity, washed with bright red or cannine on the side (xposerl to the sun. Flesh much like the Bartlett, having the unusky lavor, thomgl in a lesis degreer. 1). and s. Nejtember.

Tyson-Ifedium si\%e, bright yellow; cleek sladed with redilish brown, buttery, very melting; flavor nearly sweet, aromatic, excellent. D). and s. Feptember.

Wilder-Originated in N. Y. Tree a viegrous grower, rather smatl. Fellow, with a red eheek, fine qunlity; ripens very caly, not inclined to rot at the core.

\section{AUTUMN.}

Belle Lucrative (Fonkunte l'Automme) - I finc, laree pear, yellowish green, shightly russetted ; molting and clelicions; productive. One of the best futumn peirs. September and () (rober.

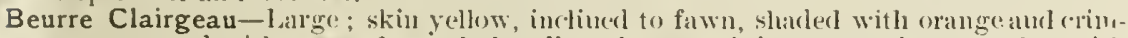
son, covered with russet dots; tlesh yellow, buttery, juicy, somewhat granular, with "l sugury, perfuncel, vinoms flavor. D). and st. October and November.

Beurre Hardy - I pear of good si\%e; cinnamon russet ; nelting and fine. Tree a goot benrer. One of the fincst pears. 1). and s. Octobex.

Beurre Bosc-I harge, finc pear, russetty yellow, slightly brownish red in the sun ; tirsh white, melting, juier, sweet, perfumed; prohetive. s. September and Octolur.

Beurre Diel-Large, dull sellow, dotted; sugary, lich and delicious. 1). and s. ( $)$ tober aud I)ecember.

Beurre d'Anjou-Larce, greenish, spriukled with russet, smuctimes sharerl with dull coimson; flesh whitish, buttery, melting, with a high, rich, vinous, exechlent flavor : very probluctive; sucereds weil on the quituce; should be in every orehath. I). and $\therefore$ October to .Jantary.

Beurre Superfin-Merlium, pale green; melting, juicy and good : very productive. 1). and $\rightarrow$ () (otober. 
Buffum-Medium size, yellow, somewhat covered with reddish brown and russet; buttery, sweet and excellent. D. and S. September and October.

Duchess d'Angouleme-Very large, dull greenish yellow, streaked and spotterl with russet ; flesh white, buttery and very juicy, with a rich and very excellent flavor; on young standard trees the fruit is variable, but on the quince, to which stock this variety seems well adapted, it is always fine; a general favorite. D. and S. October and November.

Boyenne Boussock-Large, lemon yellow, a little russetted ; melting, juicy, with a sprightly, vinous flavor. S. October.

Doyenne White (Virgalieu)-Medium, pale yellow, with a faint blush ; fine flavor. I) and S. October and November.

Doyenne du Comice-Large, yellow, with crimson and fawn cheek, and russet dots ; melting, rich, perfumed and luscious; productive. October and November.

Dr. Reeder-Fruit medium, skin yellow, covered with russet; flesh melting, juicy, sweet, with musky perfume; tree hardy and very productive; very good. S. Nov:

Eastern Belle-Originated near Bangor, IIaine. Seedling of Belle Lucritive, which it somewhat resembles: hardy enough to endure the cold of all Northeril sections. Flesh juicy, rich and meiting, with a musky flavor. September. $\mathrm{S}$.

Edmunds-Large, bright yellow, often marbled with red in the sun; melting, sweet perfumed; good bearer. D. and S. September and October.

Flemish Beauty-Large, beautiful, juicy, melting, rich and fine; goor bearer ; lardy every where. D. and S. September and October.

Frederick Clapp-Above medium, lemon yellow, sprightly, acidulous, rirh, superior to Beurre Superfin ; best. October and November.

Garber's Hybrid-Tree very vigorous, liealthy and productive; fruit medium sized, pyriform, light yellow, with a distinct quince-like flavor; valuable for canning. September.

Goodale-Originated at Saco, Maine. Fruit large, thesh white, juicy, melting, of excellent flavor and qnality. Tree hardy and uprigit in growth, and uniformly producti.e; valuable. October.

Howell-Large, light, waxen yellow, with a fine red cheek; handsome, rich, sweet, melting, perfumed, aromatic flivor. An early and profuse bearer. Very liardy and valuable. D. and S. September and Octoler.

Idaho-Size large, nearly globular, obtusely ribbed; color light rich yellow, surfare covered with many small dots ; cavity very deep and narrow, and strongly furrowerl, stem small, calyx closed: flesh white, fine grained, buttery, melting and rich. September and October.

Kieffer's Hybrid--Raised from seed of the Chinese Sand Pear, accidently crossed with the Bartlett or some other kind grown near it. Tree lias large, dark green, glossy leaves, and is of itself very ornamental ; is an early and very prolific benrer. The fruit is of good quality, wonderfully slowy and valuable for the table and market. It never rots at the core, and is as nearly blight-proof as is possible for any pear to be. D. and S. October and November.

Louise Bonne de Jersey-Rather large, greenish yellow, with a bright red cheek; juicy, buttery and melting, excellent; very productive. D. and s. Sept. and Oct.

Onondaga (Swan's Orange)-A very large, melting and lighly flavored yellow pear; productive. D. and $\mathrm{S}$. October and November.

President-Raisell by Dr. Shurtliff, of Massachusetts, where it is very popular. Fruit large, roundish, obvate; somewhat irregular; tlesh yellowish whits, rather coarse, juicy, slightly vinous. Good. November.

Rutter-Fruit medium to large, and nearly globular; skin rough, greenish yellow, sprinkled with russet; flesh white, moderately juicy, neurly melting, sweet, slightly vinous; good bearer. Very good. Octobcr and November.

Sheldon-Iledium size; yellow on greenish russet, with a richly shatled cheek; flesh a little coarse, melting, juicy, with a very brisk, vinous, lighly perfumerl flivor; productive. S. October.

Seckel-Small; skin rich yellowish brown when fully ripe, with it deep brownish red cheek; flesh very fine grained, sweet, exceedingly juicy, molting, buttery ; the richest and highest flavored pear known. September and October.

\section{WINTER.}

Beurre Easter-Large; yellow, sprinkled with brown dots, often dull red cheek: quality good. One of the best Winter pears. Best on quince. Dec. to Feb. D.

Dana's Hovey-Small size; color yellowish russet ; flesh yellowish white, juicy, melting, with a sugary rich, aromatic llavor, too small for a market variety, but as an amateur sort, most desirable. November and December. 's.

Duchess de Bordeaux-Large size, with a very thick, tougl skin, which renders it a most valuable keeper for Winter use; flesh melting, juicy, rich. IDec. to Mar. S. 



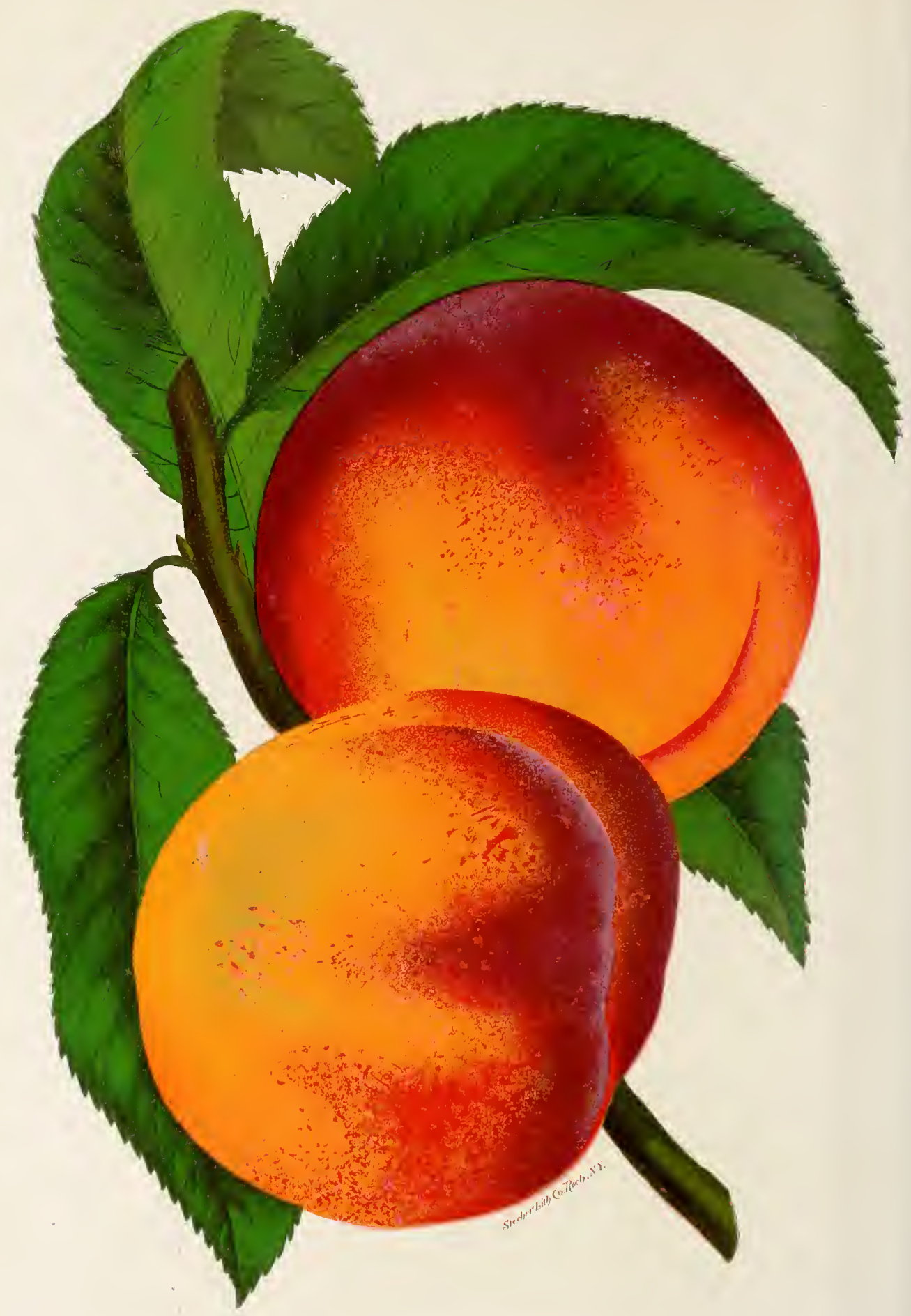

ELBERTA PEACH.

One of the largest and most esteemed of all yellow fleshed peaches ; tree vigorous and productive; a valuable acquisition. 
Glout Morceau-Large, sweet, melting, juicy and buttery ; one of the best early IVinter pears; proluctive. 1)ecember. 1$).$

Josephine de Malines-Medium, yellow, sliglitly russet; flesh buttery, juicy and sweet; a fine kecper; productive. December to March. 1 .

Lawrence-liather large, ycllow, covered with brown dots; flesh whitish, slightly granular, somewhat buttery, with a very rich, aromatic flavor, unsurpassed among the early 1 inter pears; succeds well on the quince; ripens with little care; should be in every orchard ; tree healthy, hardy and productive. Nov. and Dec. s.

Mt. Vernon-IIedium size; light russet, redlish in the sun; flesh yellowisl, juicy and aromatic; early bearer. A very good late pear. December. I). and S.

President Drouard-A very good looking and large Winter pear, witl al delicate and abundant perfume; melting and juicy. March to May. D. and s.

Vicar of Winkfield (Le Cure)-Lure, long; not first quality, but desirable for its productiveness. Best on quince. November to January. i), and s

Winter Nelis-Medium sizc; yellowish green and lusset; fine grained, melting, rucu and delieious; one of the best Winter pears; very productive. December. S.

\section{PEACHES.}

The Peach Tree requires a well aribined, moderately rich soil-a warm, sandy loam is probably the best.

lin order to preserve the continued healthy growth of the trees and the tine culuality of the fruit, the trees should have the shoots and branches shortened every y(utr, so as io preserve a round, vigorous head with plenty of young wood ; and the land slould not be seeded to grass, but kept in constant cultivition.

The following have been selected after an examination of more than one hundred different sorts in bearing, the best only being chosen. They furnish a succession for about two inonths, commencing the early part of August.

Alexander-From Illinois; very early; of good size, well growu specimens nleasuring eight inches in circumference, handsome and regular in form with deep maroon shade, covered with the richest tint of crimson, rich and good in quality wiill a vinous flavor; free-stonc. July.

Amsden-Very carly; the fruit has remarkably keeping and carrying qualitics; roundish, a little flattened, with a slight suture. Color red, heatifilly shaded and mottled with a very dark red, nearly covering the greenish white ground. Flesh white, witl a delicious tlavor. July.

Barnard's Early-Medium to large; yellow, cheek purplish red, flesh yellow, red at the stone, juicy, sweet and rich. One of the very best yellow fleshed peaches. September.

Clarissa-New, very linge, yellow flesh, fine flavor and appearance. October.

Cooledge's Favorite-Lallge white, witl crimson clieck; llesh pale, rery nelting and juicy, with a rich, sweet and ligh fiavor; beautiful and excellent. I'roductive. IIiddle to end of $\mathrm{August.}$

Crawford's Early-This very beautiful and best of yellow peathes is highly esteened for niarket purposes. Fruit very large, oblong; skin yollow, with fine red cheek; flesly yellow, juicy, sweet and excellent. Wonderfully prodnctive and hardy. Last of diugust.

Crawford's Late-Fruit of the liugest size; skin yellow or greenisl yellow, witl dull red clieek; flesh yollow; productive. One of the finest late sorts. Last of September.

Early Canada-This early Peach is a native of Jordan, Province of Ontario, Canada, a chance seedling brought out by the late $\Lambda$. II. High. Ripens one month before Craw forl's Early Freestone. Good simples measure over seven inches in circumference; unusually liarly for a Peaclis. Jifldle to (nill of July.

Early Rivers-Ne ; large, light straw color, with delicate pink cheek; flesh juicy and melting, with very rich flavor. One or two weeks carlier than Ilale's. End of August.

Early York-Medium size, greenish white, covered in the sun with dull red ; llesh greenisl white, rery tender. Middle of August.

Early Silver-Large, melting and rich, with the vinous flavor of the White Nectarine, its parcnt. One of the best. Early in September.

Foster-Originaterl in Medford, Mass. Iarge; deep orange red, becoming very dark red on sumny side; flesh yellow, rery rich and juicy, with sub-acid flavor. Warlier than Early Craw ford. Very handsome. Iast of Angust. 
Garfield, or Brigdon-Originated in Carnga Co., N. I. Flesh yellow, very rich and juicy ; color deep orange red, beconing dark red on the exposed side ; very attraciive; foliage large, green, glossy and peculiar. Middle of Scptember.

George IV-Large white, with refl eheek; melting, juicy and delicious. Moderate bearer. Last of August.

Honest John-Medium to large; yellow ; flesh yellow and of good quality. Tree vigorous and productive. First of September.

Hale's Early-Fruit medium size, skin elear, smootl, white, delicately marbled with bright and dark red on the sunny side; flesh very melting, juicy, and high flavored. Tast of July.

Hill's Chili-Medium size, dull yellow, tree rery hardy, a good bearer ; highly esteemed as a market fruit in Westeru Hichigau. Laist of September.

Jacques' Rareripe-Very large, deep yellow; las a ligh reputation. Last of August.

Large Early York-Large, white, with a red cheek, fiue grained, very juicy, rich and delicious ; vigorous and productive; one of the best. Last of August.

Lnrd Palmerston-Very large; skin creamy white, with a pink elieek; flesh firm, yet melting ; very juicy and rich. Middle to end of September.

Morris White-ILedium, straw color, tinged with red; juicy and delicious; productive. Middle of September.

May's Choice-A yellow Peach of the highest quality, ripening immediately after the Early Crawford; in size and form closely reseubling that variety, but superior to it in richmess of color and ligh vinous flavor; tree a good bearer; very desirable. Last of August.

Mountain Rose-Large; red; flesh white, juicy, rich and excellent; one of the best early Peaches, ripening with 'Troth's Early, and much larger and finer than that variety. Should be in every collection. First of August.

Old Mixon Cling-Large; pale yellow, with red cheek; juicy, rielı and high flavored ; one of the best clingstone peaches. Last of September.

Old Mixon Free-Large; pale yellow, with deep red clieek; tender, rich and good ; oue of the best. First to midlle of September.

Richmond-Large, globular ; skin orange yeilow. with a deep red cheek; flesh mellow, pink at the stone, very juicy, fine flavored, resembling the Early Crawforl in qualit $F$, but less acid, and superior ; ripeus a few days later than the Early Crawford ; strong grower and hardy. First of September.

Salway-Fruit large, roundish, deep yellow, with a rich, marbled, brownish red cheek ; flesh firm, juicy, rich and sugary. A new Euglish rariety, promising highly as a late showy market sort. First of Oetober.

Schumaker-Originated at Fairview, Pa. Hedium to large, bright yellow, splasled with crimson; juicy, melting and rich; parts ireely from the stone when fully ripe. Middle of July.

Sener-Large, yellow, with deep red cheek; yellow Hesh, deep pink around the stone; freestone, rich aud very juicy. First of Uctober.

Steven's Rareripe-Fruit resembles our enlarged Old Mixon Free, being of very ligh color and very beautiful. Very productive and free from disease. Commences and ripens inmediately after Late Crawford, and coutinues three or four wceks. Last of September and first of October.

Steadley-Large, round, of a greenisl white color, flesh wlite to the stone, and of a delicious flavor ; freestone; very hardy. First of October.

Stum? the World-Very Jarge, roundish; skin white, with a bright red eheek; flesh white, juicy and good. Fnd of September.

Susquehanna-One of the handsomest peaclies; large, sellow and red, melting, rich aud good ; origin, Pennsylvania. Last of September.

Wager-Very large, yellow, more or less eolored on the sumny side; juicy, and of fine flavor; bears uniform and large erops, even when other sorts fail. Laist of August.

Wheatland-Thirty-nine peaches weighed 18 pounds. Was awarded the first prize for size, quality and beauty, at the New York State Fair. Ripens between Early and Late Crawford, and larger than either of them. First to middle of September

Wiider-Tree a very vigorous grower; hardy and produetive. Fruit medium to large ; round ; flesh vely juicy and rich. Last of July.

Yellow Rareripe-Large, deep yellow, dotted with red; melting and juicy, with a rich flavor. Last of August.

\section{ADDITIONAL LIST OF PEACHES.}

Amelia-From South Carolina; very large and beautiful, white, nearly covered with crimson ; flesh white, juicy, melting, sweet, rich, vinous. Last of July.

Beer's Smock-Large size, yellow flesh, described as an improvement on Smock's Free, which it resembles; ripens a few days later, and is a better annual bearer. September and Oetober. 


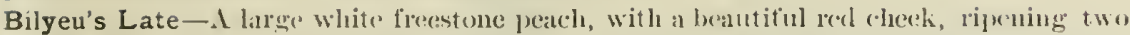
weeks litter than smock Free. October.

Briggs' Red May- Ilout medium; very highly colored : flesh greenish white, very juicy, vinoms, and of rery good quality; acliheres somewhat to the stome; of firm texture, and proves well is a shipping jeach ; tree very prolitic. Midale to and of July.

Chair's Choice-Very large. clenp yellow with red rhese ; flesh very firm, fine for des-

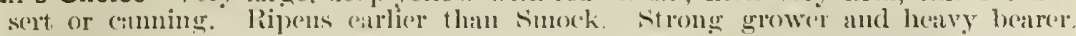
Sieptimber.

Chinese Cling - Frnit large; roundish ovill ; skin transparent cream color, with malrbling of red next the sun; Hesh cre:me white, very juicy and melting, with a rich, agreeable flivor. Iast of July.

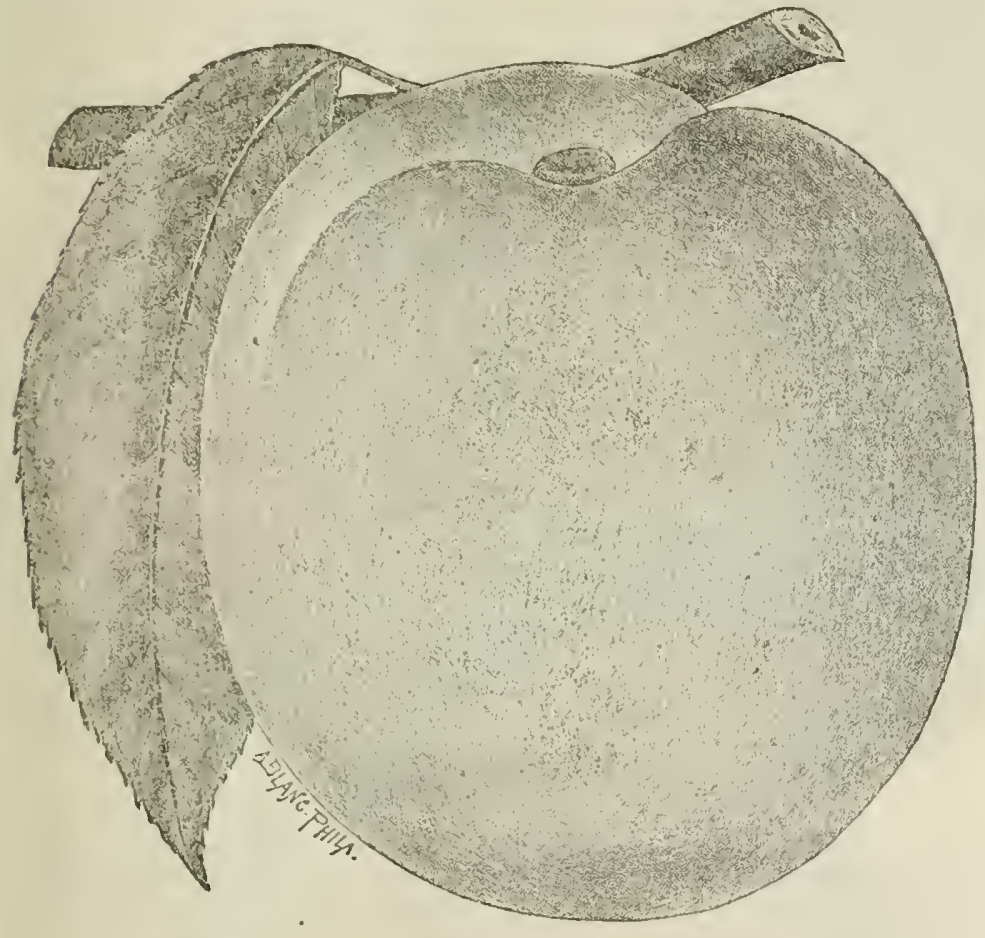

Colunbia - Very large; skin downy, dingy yellow, and striped with dıll brown or red ; flesl yellow, buttery, melting. and excedingly rich. liipe about July 20th, and (ontinues for a month. Jalst of July.

Grand Admirable Cling-Full medium size; skin white, nearly covered with red ; " verv lim ndsome and excellent peach, and a good bearer. First of August.

Golden Drop Transpancent golden yellow, very attractive, quality fine, productive and narey. Ripens after Late Criwford.

Globe-. rapid vigorous grower and an enornous bearer ; fruit very large, globular in form; tlesh firm, juicy, yellow, shaded with reldish crinson towards the pit on stone; quality good ; very rich and lnscious. September and October.

Large Red Rareripe-i most excellent peach ; frust large ; skin greenisil white; dotterl, and witl a beautiful rich red cheek; flesh white, red at the stone, melting and juicy, with a sweet and rich flavor. Farly in Lugust.

La Grange-Iange; greenish white, slightly reddened in the sun; flesh white to the stone; juiry, sweet and rich. Freestone. Midelle of september.

Lady Parham-Of Soutlern origin; fruit of medium size; skin greenish white, with sometimes a blush cheek; flesh white, juicy, vinous and highly blavored ; a first rate variety ; freestomi. List of september. 
Lemon Free-Originated in Ohio. Tree very hardy, and very profitable; color a pale yellow when ripe; size large, over twelve inches in eircunference; quality fine; ripens after Late Craw ford.

Late Rareripe-Large; pale greenish yellow, marbled and covered with reddish spots: cheek dull, deep red, mottled with fawn colored specks; llesh white but red at the stone; very juiey, melting, and of rieh, ligh fluvor ; very productive. Early in sicp.

Moore's Favorite-Resembles Old Mixon Freestone, and some think it identieal with that very popular sort, while others claim that it is a distinct variety. First to micldle of September.

Mary's Favorite-Large; skin white, sometimes a purple cheek on exposed side; flesh white to the stone; juiey, sweet and rieh; an exeellent sort for canning. Last of Aug.

Picquet's Late-A Georgia variety of large size; yellow with a red eheek; flesh yellow, melting, sweet, of the highest flavor ; freestone; a valuable aequisition. September.

President-Large; skin pale yellowish grecu, with a red cheek; flesh white, but rei at the stone, juicy, melting, rich and ligh flavored. Middle of Au gust.

Raymond Cling-Large; greenish yellow, with a fine red eheek; flesh white; juiry. sweet and very good; well deserving a place in the oreliard. Middle of September.

Reeve's Favorite-Large, oblong; skin deep yellow, with orange eheek; flesh juicy and buttery, very sweet, good ; freestone. Middle of July.

Scott's Nonpareil-A fine, large, yellow peach, from New Jersey. A good market variety. Middle of September.

Snow's Orange-Originated in Michigan and popular as a market variety; lardy, produetive, and valuable; an excellent yellow fleshed freestone.

Sturtevant-Originated near Cleveland; one of the best yellow fleshed peaches; skin downy, rich yellow, eovered nearly with dark rich red in the sun; Hesh yellow, red at tlie stone; freestone. Last of August.

Troth's Early-Medium size; whitish, with a fine red cheek; flesh juicy, sweet and very good ; one of the most popular and profitable varieties for carly marketing. Middle of July.

Ward's Late Free-Medium to large; yellowish white, with a red rlicek in the sum; flesh nearly white, juicy and good; valuable for late preserving. Tree vigorons. First of Oetober.

Wonderful-Originated in New Jersey. Large to very large, uniform in shape and size; color rich golden yellow, overspread with carmine and rimson. Flesh yellow, ligh flavored, and firm; bright red at the pit, which is small and parts frecly from the flesh. Ripe in Oetober, and keeps well.

\section{Plums.}

The Plum, like the Pear and other finer fruits, attains its greatest perfection on our heavy soil, being entirely free from disease. The cureulio, a small, dark brown beetle. often stings the fruit, eausing it to drop off; but the following directions, faithfully observed, will seeure a good crop of this splendid fruit everywhere.

As soon as the blossoms are fallen, spread two slieets under the tree, and give the tree a sudilen jar by striking a smart blow witl a hammer upon the stub of a limb sawed fron the tree for the purpose ; the insects will drop on the sheet and ean be killed. Collect all the fallen fruit and burn or feed to swine. Repeat the operation every day for two or three weeks. It should be done before sunrise.

The eost of proteeting large orchards from the attacks of this enemy will not excex] teu cents per tree for the entire season.

Abundance-Equalling in thrift and beauty any known fruit tree. An early and profusc bearer ; fruit very large, somewlat oval ; amber, turniug to a riel elierry red, witl in decided bloom; Hesh liglit yellow, exceedingly juicy and tender, with a ricli sweetness; has a small stone and parts readily from the flesh ; ripens in advanee of other plums.

Boton-Lemon yellow gromnd, nearly overspread with bright cherry, and heavy bloom: large to very large; oblong, tapering to a point like IVild Goose; flesh orange y'(2llow, melting, rieh and highly perfmmed. Tree vigorous and hardy.

Beauty of Naples $-\Lambda$ variety of the lighest promise: size large; color greenisl frellow. Flesh firm, juicy and very fine flavored ; tree very hardy and prolific." Sept.

Bleecker's Gage-Above medium ; yellow ; juicy and ricli ; productive. August.

Bradshaw-Fruit very large, dark violet red ; flesh yellowish groen, juic'y and pleasant: proluctive. Auerust. 


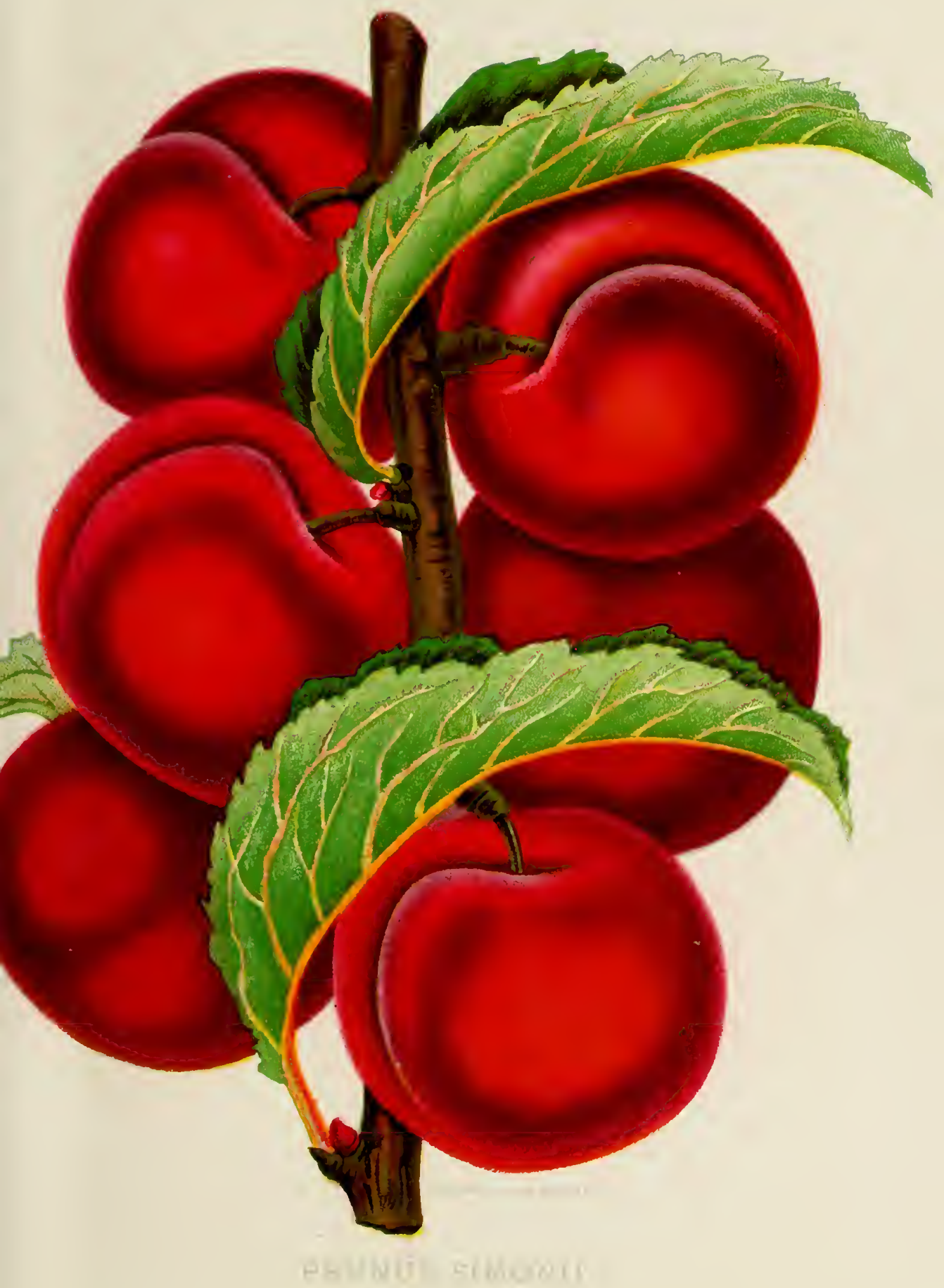





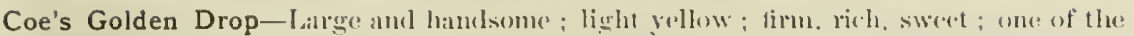
best late plums. Sicitember.

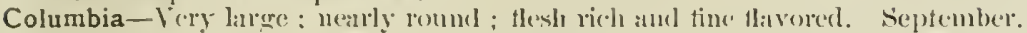

Damson-Fruit sntill, oval; skin purple, ("overecl with blue bloom; flesh melting ant juicy, rather tart; separates freely from the stome. Sieptember.

Denniston's Superb-Mediun size. round, dottel with purple: handsome, quality good; good beitrer. Iugust.

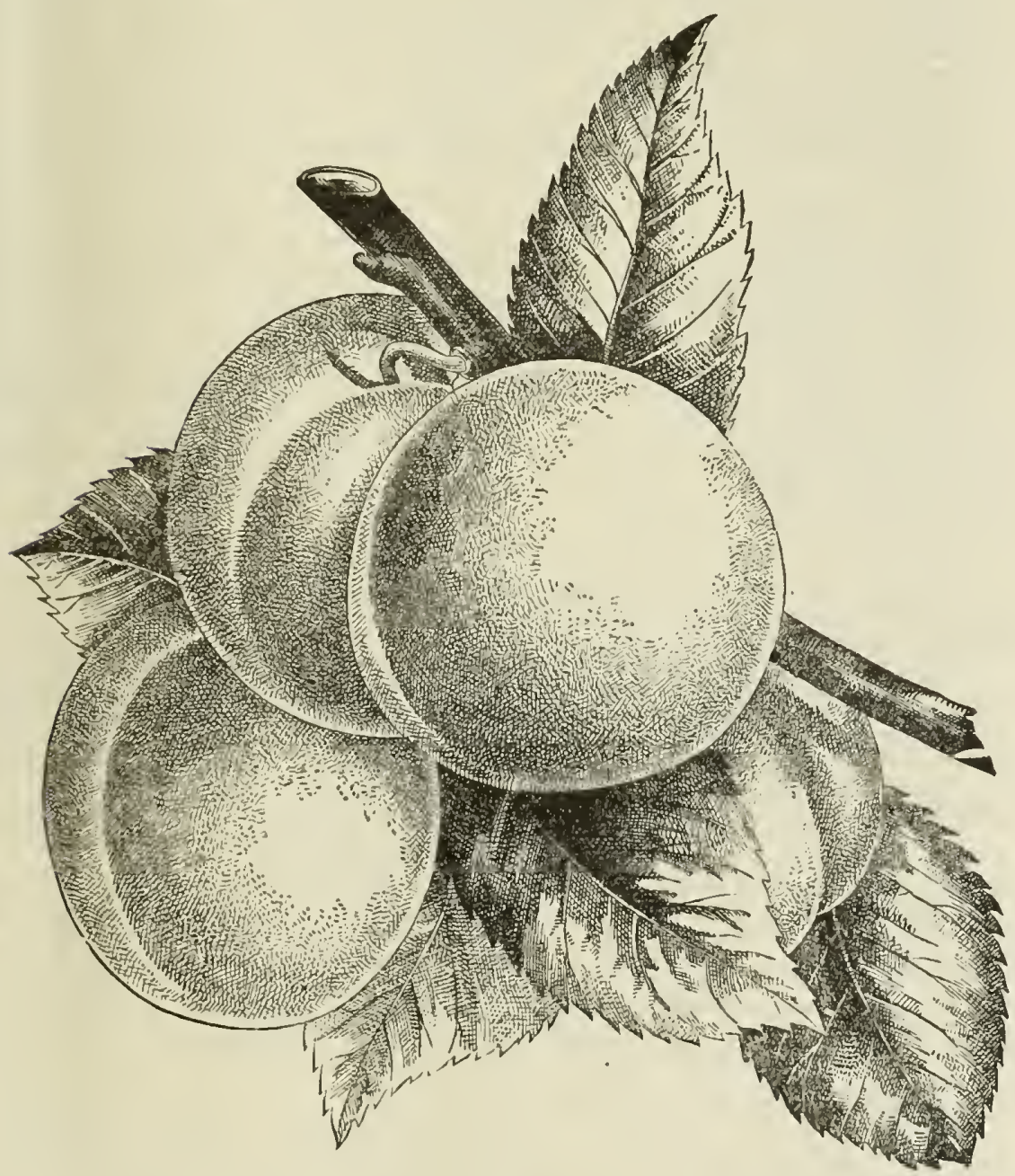

IBOTAX

Duane's Purple - Large size, roundish and oblong, rolor a reddish purple; fickh juicy and good ; very handsome; bents well. september.

Fellenberg -(Italian Prune)-I fine latt: plum; oval, purple, flesh juicy and delicions ; parts from the stone; fine for drving. Tree very productive. September.

Garfield-A variety of the Chickasiw, seedling of Wild Goose, producing ill ilbundance of good sized, reddish-purple fruit; ovil in slape, ripens in september, amel keeps till November.

Glass' Seedling-Raised in Grelph, Ont. Tree hardy, very productive; frnit very showy, valuable for market and culinary purposes; linge, dark, pulple, almost black, with a thin, blue bloom. Flesh a little coarse, moderatcly sweet ind juicy. September. 
Green Gage-Small ; eonsidered the standard of excellenee for quality. August.

General Hand-Very large, oval; golden yellow, juicy, sweet and good. September.

Geuii-Fruit very large, deep bluish purple, eovered with thick bloom; flesh rellowisl green, eoarse, sweet and pleasant; great bearer and very early; tree a liurly and rapid grower. This new variety is regarded as very valuable for market by growers along the Hudson River. September.

German Prune- $\Lambda$ large, long, oval variety, much esteemed for drying; color dark purple, of very agreeable tlavor. September.

Huling's Superb-Very large and handsome; yellowish green; juicy, rich and good. August.

Hudson Gage-Medium size ; yell ww, with streaks of grcen; very juicy, melting, rich and fine; productive. August.

Imperial Gage (Flushing Gage, Prinee's Imperial Gage)-Fruit large, oval, skin pale green, flesh juiey, sweet, rieh and exeellent. Tree very vigorous and produetive. August.

Jefferson-Large, yellow, reddened in the sun; juiey, rieh and delicious. One of the best. August.

Kelsey-Fruit large to very ıarge, heart-shaped, rielı yellow, nearly overspread with light red, and a delieate bloom; flesh firm and melting with a remarkably snull pit. Tree not quite so hardy as a Peaeh. Ripens last of August.

Kingston-Originated at Roehester, N. Y. Fruit very large and showy; of good quality, firm flesh and rieh flavor. Fine for preserving, August.

Lombard (Bleecker's Searlet)-Medium, round, oval; violet red ; juiey, pleasant anul good; adheres to the stone; produetive. A valuable market varicty; one of the most hardy and popular. August.

Lawrence's Favorite-Large, yellowish green, remarkably juiey ind melting. One of the best ; productive. $\Lambda$ ungst.

McL aughlin-Large, yellow, firm, juiey, luseious ; productive. Nearly or quite equıl to the Green Gage. August.

Mariana- $-\Lambda n$ aeeidental seedling originating in Texas, An unusually strong, rapicl grower. Fruit larger than the WVild Goose. Round, and of a peculiar light red eolor. Its produetiveness is marvellous; one of the best of the Chiekasaw varieties. Aug.

Monroe-Iledium, excellent; vigorous grower and abundant bearer. September.

Moore's Arctic-Originated in IIaine, and eelebrated for its remarkable harcliness, frecdom from curculio, and great bearing qualities. Fruit grows in large clusters: large, dark purple; flavor very fine, both for preserving and dessert. A long keeper.

Niagara-Origin uneertain; very large, reddish purple, entirely eovered with gray blooin ; flesh deep greenish yellow. Resembles Bradshaw. August.

Ogon-Fruit large, round, bright golden yellow, with faint bloom, and some red on the sunny side; Hesh firm, sweet, rieh and dry. Tree vigorous and hardy. Iugust.

Pottawattomie-Tree a strong, vigorous grower; perfectly harly, and an immense bearer. Fruit yellow, overspread with bright pink, and prominent white dots: No astringeney in skin or pulp. Claimed to be eureulio proof.

Peach-Very large and handsome, dull red; good ; very productive. August.

Pond's Seedling-A magnifieent English Plum; light red, changing to violet; flesh rather eoarse ; abundant bearer. One of the most attractive in eultivation. Sept.

Purple Egg (Hudson River Purple Egg)-Highly esteemed by growers along the Hudson River; described as one of the richest and finest flavored plums we liave ; stone free; good size, resembles the German Prune-a little larger, with a nice bloom; good bearer, and brings good price in market ; tree bears young. Oetober.

Prince's Yellow Gage-A bove medium size; deep yellow ; flesh yellow, rich, inelting and sweet; produetive. August.

Quackenboss-Large, oblong, oval, deep purple, a little eoarse, spriglitly, juiey, sweet and exeellent. Adheres slightly to the stone; produetive. Valuable for market. Oetober.

Red Egg (Red Magnum Bonum)-Large red ; firm flesh ; sub-acid. September.

Reine Claude de Bavay-Large, nearly round ; pale yellow ; marked with red ; juicy. melting and excellent; good bearer. September.

Saratoga-Originated at Saratoga Springs, N. Y. Reddisll purple, overspread witl a handsome bloom. Supposed to be a cross between Lombard and liadshaw ; longrer and larger than Lombard, and broader than Bradshaw.

Satsuma-Native of Japan. The tree looks much like the Wild Goose, and is likely to prove more hardy than Kelsey. The fruit lias a pleasant flavor, and, unlike all others, has red flesh with a renrarkably small stone.

Schuyler Gage-Medium size; yellow, dotted and marked with red in the sun ; juicy, ricll and sweet; productive. September.

Shipper's Pride $-\Lambda$ large blue Plum ; very lurdy and productive and possessing remarkable qualities for market. September. 
Shropshire Damson-1 Plum of fine quality, as free from the attack of the enroulio as the eommon Dimson, anel of same color. The thesh is amber colored, juicy and sprightly. September.

Simoni (Apricot Plum)-Except in the veining of the leaves tho tree resembles the Prach. Fruit a brick-red eolor; that; tlesh apricot fellow; firm, with a peculian aromatis flavor; hardr, and valuible as an ornamental fruit tree ; bears abundantly and rery young.

Smith's Orleans-Large size. reddish purple; flesh firm and juicy, with a rich, finc flavor ; produetive. September.

Spaulding-Tree a strong grower", with broasl, lich dark foliage; frut latge, yellowish green, with marblings of deeper green, and il delie:ate white bloom ; flesh pale yollow, very firm, sprightly, sugary and rieh; fine for canning. Claimed to be cureulio proof.

Stanton-Originated in New lork State. The tren is a vigorous, healthy grower ; fruit medium to large, nearly round, deep purple, with blue bloom; (guality best. Ripens and keeps rather lite.

Victoria (Sharp's Emperor)—One of the most magnificent Plums in eultivation ; of the largest si\%e, fair quality: purplish reci color ; most abundant bearer. September.

Weave:-Fruit large, purple, with a blue bloom ; very plolific: ; a constant and regular bearer and of gool quility. The tree is rery hinely, not being injured in the severest winters, and will thrive even to the Northerul linits of the I'nited States. Mugust.

Washington-Very liuge; when ripe, clear yellow, nutked with red ; tlesh firm, vary juicy and excellent ; rery popular ; productive. Lugust.

Wild Goose-Fruit medium, purple, with a bluc bloom; hesh juicy and sweet. July

Yellow Egg, or Yellow Magnum Bonum-Very large, egg-shaped; excellent for cork ing ; good, and productive. Angust.

Wolf-Vearly as large as lombard, and a perfect free stone; superior for eooking and serving witl sugar, as Peacles are userl. Tree a goul grower ; verp hardy, and is beeming popular wherever known. Ripens in lingust.

\section{CHERRIES.}

The Cherry tree universally requines a dry soil, and is naturally a lately tree, sueeeeding in tle lightest soil or livest situations. 'l'he lf(a)t and Bigarreau varieties are of rapid growth, with large glossy leaves, forming fine, pyranid-slated heads, and producing large crops of luscious fruit ; are woll atlapted fiol planting along the streets, or in yarils as shate trees.

They are profitably grown for market. Many trees produce from five to six bushels per tree. The fruit brings in market, one yeal with another, $\$ 2$ to $\$ 3$ per bushel.

\section{HEART AND BIGARREAU CIERRIES.}

Black Eagle-Large black, very tender, juicy, rieh and high flavored ; productive. July.

Black Tartarian-V'ry large, bright purplish blaek; half tender, juicy, very rich, excellent flavor; productive. Junc.

Coe's Transparent-Medium size, pale amber, red in the sun; tender, juicy, rich, liandsome; one of the lost ; productive. June.

Downer's Late Red-Iarge, light red: trnder, juicy and delicious ; produrtive,

Early Purple Guigne (Early Purple) - 'l'he earliest fine variety; medium siza, hemtshaped; tender, juicy and sweet : very hardy and productive. June.

Elton-Large, and fine Havor, pale yellow, light led next the strm. June.

Elkhorn (Truleseant's Black Heart)-I fine, large, blaek eherry, of good quality ; produetive. July.

Gov. Wood-Raised by Dr. Kirtland, and one of the hest eherries; very large, light rerl ; juicy, riels and delicious. T'ree healthy and a great bearer. June.

Knight's Early Black-Large, black, tender, juicy, rich and 'xc'ellent; productive. Julle.

Luelling - A variety from Portland, Oregon; of very dark color and finest qualitx; flesh solid and firm, and adiuted to long transportation. Juwe.

Napoleon Bigarreau-Very lirge, pale yellow or red ; vory tirm, juicy and sweet ; very produetive; one of the best. July.

Rockport Bigarreau-Iarge, pale anibel with elenr rol; a very excellent and lantsome cherry ; grool bearer. June.

Schmidt's Bigarreau-Originated in Belgium. 'The tree is reniarkably vigorous, hardy airl proc]uetive. Fruit grows in elusters, and if of the lirgest si\%c; skin (leep, biack; tlesh slark, tender, juic.5, with a finc, rich flator; stome small. I clecidel ncoulusitioli to our list of cherries. June to.July. 
Sparinawk's Honey-ILdium, red; a very sweet and melting vallety ; ripens late and will hang for sone tine on the tree; productive. June.

Yellow Spanish-Large, pale yellow, with red cheek; firm, juicy and excellent ; one of the best light colored eherries; productive. June.

Windsor-Originated in Canada; fruit large liver eolored; flesh remalkably firm, sweet and of fiue quality. 'T'ree liardy and very prolifie.

\section{DUKE AND MORELLO CHERRIES.}

These are for the most part, round shaped ; fruit generally acid, though some varieties have a very mild, pleasant flavor. 'The trees are naturally of a smaller growth than the preeeding class, and well adapted for Dwarfs or Pyranids. The Morellos are more slender and sprealing in habits than the Dukes, which are of stocks, upright growth. Both are more larily than the Hearts and Bigarreaus, and m demand where the former eannot be grown with advantige.

Belle de Choisy-Medium, amber mottled with red; tender, juicy, sweet and rich. June. Belle Magnifique-Fruit large, roundish; skin bright red; Hesh tender, juicy, sprightly, sub-acid ; one of the finest of this elass of cherries. Tree liarly and very productive. July.

Dyehouse-Partakes of both the Duke and Morello in wood and fruit ; a very eally and sure bearer; ripens a week before Early Richmond, of better quality, and quite as produetive, June.

Empress Eugenie-Fruit largc, dark red, very rich, tender and sub-icid. A superior variety. July.

English Morello-MTerlim to large; blackish red, rich, acid, juicy and good ; very productive. August.

Early Richmond-(Kíentish Virginian May)-Medium size, dark red ; melting, juicy sprightly acid flavor. This is one of the most valuable and popular of the acid cherries, is unsurpassed for cooking purposes, and is exceedingly produetive. June.

Late Duke-Large, light red; lite and finc. July.

Large Montmorency-I large, red, acid cherry, larger than Early Richmond, and fully ten days later. June.

Louis Phillippe-Very productive; fruit large, roundish, regular; color, rich dark, almost purplish black red; flesh red, tender, sprightly; mild acid; good to best. July.

Leib-1 Morello, one week later tban Early Richmond, and claimed to be very superior.

May Duke-Large, dark red, juicy and ricli; and old excellent variety; productive. June.

Olivet-Of Freneh origin. luarge, globular, very shining, deep red sort; flesh red, tender, rich and vigorous; very sweet, sub-icid flavor. June.

Ostheim-A hardy chcrry, from Russia. It lias been tested in the severest winters of Mimmesota and has been found perfectly hardy. Fruit large, roundisll, ovate; skin red, dark at maturity ; stalk long ; flesh liver-colored, tender, juicy, almost sweet.

Reine Hortense-Very fine; large, bright red; juicy and delicious, and productive. July.

Wragg-Supposed to hail from North Germany, very hardy. The tree is a good grower and an inmense bearer ; fruit a dark liver color, juicy and rich.

\section{NeCTARINES.}

A most delicious, smooth-skinned fruit, which thrives wherever peaches will grow, but it is liable to be stung by the curculio, and requires the sine treatment as plums.

Boston-Large, deep yellow, with a bright blush and mottlings of red; sweet and a peculiar, pleasant Havor; freestone; the largest and most beatiful variety known ; hardy and productivc. September.

Early Violet-Medium sized, Jellowish green, nearly covered with dark purplish red; juicy, rich and high flavored. August.

Early Newington-Large, pale green, nearly covered with blotches of red; juicy, rich and sweet ; probably tlie best elingstone Nectarine. September.

Elruge-Medium size, pale green, with a dark red cheek; Hosli pale green, very juicy und rich. September.

Hunt's Tawney-Medium; pale orange; juicy, rich and excellent ; very carly and productive ; the best of its season, and worthy of general cultivation on account of its hardiness; freestone. August.

Pitmaston Orange-Fruit large; skin rich orange yellow, with brownish led clecek; Hesh rleep yellow, red at the stone; melting, juicy and rich ; fine flavor, frecstone.

Red Roman-Large size, greenish yellow, witl a diuk, dull red eheek ; flesh yellowish, fine and rich ; productive. September. 


\section{Apricots.}

I delicious fruit of the plum species, valuable for its atriuess. It is liable to bo attacked by curculio, ant repuires the same tratment as the plum; it bears iumense? (०ops ; ripeus iu July and Iugust.

Breda-Simall, dull orange, marked with red; juicy, rich aml vinous; productive and liardy. First of August.

Early Golden (Dubois)-Simall, pale orange; juicy and sweet; landy and productive. Filst of July.

Hemskirke-Large; bright orange, with a red cheek; juicy, rich aud luscious ; large: and remarkably handsome Euglish variety, and one of the very best. Lid of July.

Large Eariy-Irelium; orange, with a red check; sweet, ricll and juicy; out of the loest early sorts. Midclle of July.

Moorpark-One of the largest; oringe, with i red rlueck; lirm, juicy, with a rich flavor; very prochuctive. Augusl.

Peach-Tery large; orange, with a dark rheek; juirg and high tlavored ; similat to Monrpirk. August.

Roman-1 remarkibly hardy and prolific Apricot, proulucing gool crops where none others suceeed; flesh rather dry. Eud of July.

Royal-Large; yellow, with an orange check; juicy, rich aud delicious; "n very fine variety, and woll deserving a plite in collections. End of July.

St. Ambroise-Large; oblong; very sugury and rich; a vigorous grower and v'ly productive. Mliklle of Iugust

\section{RUSSIAN APRICOTS.}

These are quite distinet from the Europcau varieties. Their leading charateristics are extreme hardiness, laving withstood 30 degrees below zero withont injury ; early bearing, productiveness, and freedom from insect lavages and cliseases. The following are the best that have been thoroughly tested.

Alexander-Tery hady, an immense bearer; fruit laroge, yellow, Hecked with red ; lery bentiful, sweet and delicious. July.

Alexis-Very hardy, an abundant benter ; yellow with red clicek, large to very large, slightly acid, rich and luscious. July.

Catherine-Very hady, vigorous and joductive; medium sized, yellow, mild, subacicl, good. July.

Gibb-Tree hardy, grows symetlical, productive; frut nuedium, ychlowish, sub-aceid, juicy and rich; the best early variety, riproing som after strawberies. I great acpuicition. last of June.

J. L. Budd-Tree a strong grower and profuse bearer; fruit large, white with red cheek; sweet, juics, with a sweet kernel, as fine llavorol as an almond ; the best late variety and a decided acquisition. August.

Nicholas-Tree hardy and prolific; fruit medium to large, white, sweet, aul moltiug ; a handsome and valuable varicty. July

\section{QUINCES.}

The Quince is attracting attention as a nurket fruit. The tree is hardy and compact in growth, repuires but litile space, productive, gives regular crops, and comes early into bearing. The fruit is much sought after for canning for winter use. When put up in the proportion of about one quart of quinces to four of other fluit, it imparts to them a most delicious flavor.

It flourishes in auy good garden soil, which should be kept mellow and well enriched. I'rune off all the dead and surplus branches, and thin out the fruit if bearing too fleely: Apple or Orange-Large, roundislı; birglit golden yellow ; cooks tender and is of rery excellent flavor. Taluable for preserves or tlavoring; very proluctive; the most popular and extensively cultivated variety. October.

Angers-Somewhat later than the preceding: fruit rather more acid, but cooks well ; an abundant bearcr. October.

Champion-. I variety originated in Connecticut, The tree is a prolific and constant bearer ; fruit averagriug larger than the Orange, more oval in slape, fuality "(xually fine, and a lonerer keeper. October and November.

Rea's Mammoth-I seedling of the Otange Quince; nue-third larger ; of thr same? form and color; fair, landsome, equally as good and productive. ()(tuber. 


\section{GRAPES.}

The vine comes quickly into bearing, yielding fruit usually the second year after planting; requires but little space, and when properly trained is an ornament to the yard, garden or vineyard.

The soil for the Grape slould be dry; when not naturally so, should be thoroughly drained. It should be deeply worked and well manured, always bearing in mind that it is an essential point to secure a warm, sumny exposure.
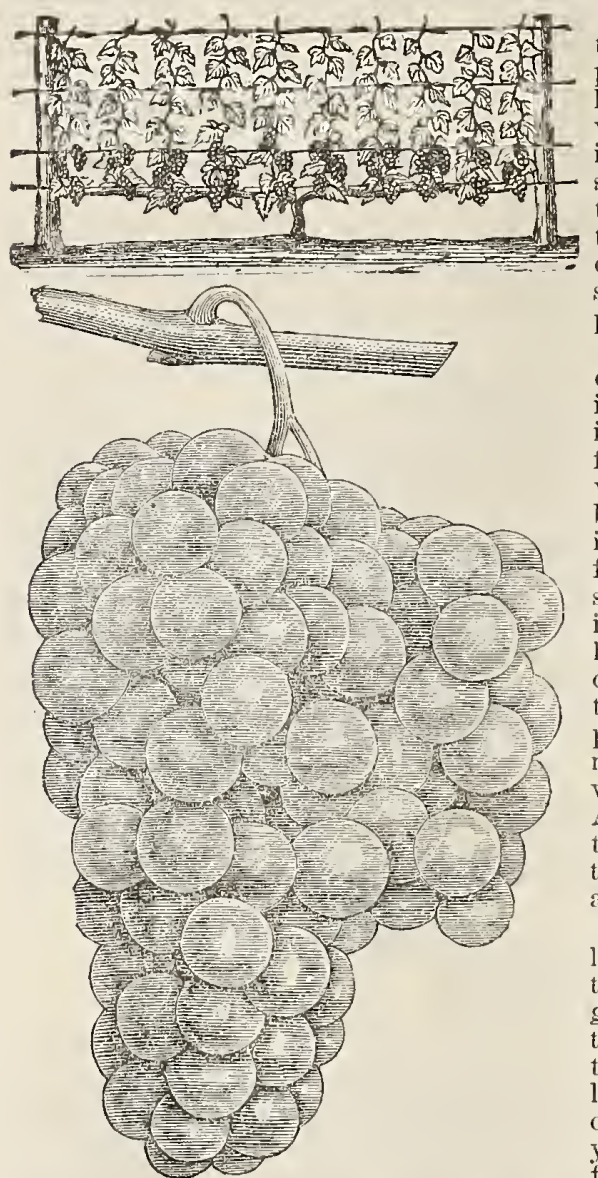

The best grape vine trellis is probably the wire trellis. This is constructed by planting posts as far apart as you choose to have the length of your trellis, stretch the wires, four in number, about eighteen inches apart, letting them pass through stakes at proper distances from each otlier to support the wire. As the wires are coutracted by the cold, and are likely to break or sway the posts from thejr places, they should be loosened as cold weather ajproaches.

To secure the best results, annual and careful pruning is essential. The following is regarded as the best method: Commencing with a good strong vine, such as we furnish, permit it to grow the first seasorl without pruning. In Norember or December following cut back the growth, allowing but three or four buds to remain. 'The' following Spring allow but two of the strongest buds to throw out slioots. These, in the Fall, will be from seven to ten fect long. and shonld be cut back to within four or five feet of the root. The next Spring the vine should be fastened to the lower part of the trellis. When growth comnences, pinch the buds so tliat the shoots will be from ten to twelve inclies apart. As these grow, train them perpendicularly to the second, third and fourth bars of the trellis. No fruit slould be aliowerl to sci above the second bar of the trellis.

During the season when the shoots lave reached the upper part of the trellis. they may be pinched to prevent furthor growtl. After the fruit is grathered, and the vine has shed its foliage, the cane shonld then be cut back to two buds. The fol. lowing Spring allow but one bud to throw out a shoot, aud treat as in the previous year. This system of pruning slionld the followed each year. After the vine lias undergone the Fall pruning it may be laid upon the ground and covered with boughs to protect it through the Winter. Grape vines should be top-dressed in the Spring.

Amber Queen-Very carly, hardy, and a strong grower ; leaf strong and thick, sonewhat downy on under side; amber eolor. Tender to the center and suall seeds. Buncli large and shouldered like the Hamburg; berry large, frequently oblong, loolds persistently to the bunch, and cannot be pulled off without breaking the skin.

August Giant-Bunches very large, with rather long and very strong stem; when shouldered, the shoulders are always short and very double; berries very large, somewhat oblong, often measuring 18 inehes in diameter. Quite tender to the center : very rich and fine.

Beauty-Red; ripens between Concord and Catawba; said to be superior iu yuality to Delaware. Vine vigorous, healthy and productive. 
Brighton-A eross botween the C'oncord and Diana IIamburg. It gives the best of satis. filction. Bunches large, berries of medium size, dark red; flesll swoet, trucler, and of the higlest (1nility. IRipeus eatrlier than the Delaware.

Catawba-Bunches large and loose; berries large, of a coppery red eolor, becoming purplish when well ripened ; ripens with Isubella; requires the most favorable soils and situations, gool culture and warm seasons, to mature perfectly in Western New lork.

Centennial-Color greenislt white, with blushl in the sun; bunch large, long and slouldered ; herries medium, tlesll very sweet und juicy, and of good quality ; skin thin but tough. Vine vigorous, healt ly and hardy, is productive and a good keejer.

Champion (Talmaun)-This varety is valued elictly for its earliness, being a number of days earlier than the Hartford, and nearly or quite equal to the latter in flavor.

Concord-A popular variety where the eloiec kincls fail to ripen; universally healthy, vigorous and productive; flesh somewhat buttery, noderitely juicy and sweet. l3unel large, nearly black, with bloom; atrly.

Cottage-Scedling of Concord, a little smaller in bunch and berry, more eompa( sweeter, and a few days earliel. Vine a rank grower, liealthy and hardy.

Delaware-One of the finest eriples. Bunches smill, compact, slonldered ; berries rather small, round; skin thin, light red ; flesh very juicy, without any liarl pulp, with an exeedingly sweet, spicy and deicious tlavor. Vines moderately vigorous, very hardy and produetive.

Diana-Bunclies a little above medium si\%e, compact; berrics large light real, very juicy and sweet, with distinet, spiey, refreshing thavor; vine a vigorous grower, and bears well ; ripens a little before the lswbella.

Downing- $\mathrm{A}$ black wrape; bunches rery large, compact and shomldered ; berries large to very large, flesh lim, neaty, tender, sweet and rich ; vine viugorons, healthy and productive; ripens witl Concord.

Dracut Amber-A very carly red grape, large in lunch and borry, sweet but foxy ; vine hardy, healtly and vigorous. Faluable for the Nortll.

Duchess-Tlie Inchess originated will A. J. ('tywood, in Llster county, N. Y. Bumch medium to larire. Often eight ineles long, shouldered, rompact; berries medium, round, greenish white; skin thin; flesli tender, witlout pulp, rieh and delicious. Ripens witl the Delaware.

Eaton-Blaek; bumcli and beriy of tlie very largest size; not quite sc early or sweet as its parent, the Coneord, but less foxy, plensant, juicy, with tender pulp; vine very vigorous, healthy and produetive. Originated in Missiclusett:

Etta-White; seedling of Elvira, which it resembles, but has larger berries and firner skin, is less componet and better (juality. The vine is a vigorous grower, healthy, lardy and proluctive: ripens litte.

Empire State-Bunclies large, from six to ten inches long, shouldered; berry medium to large, rounclistr oval ; color white witl very light tinge of yellow, covered with a thick, white bloom; leif thick, smoc il underside; flesll tender, juiey, riel, sweet and spriglity, with a slight trace of native aroma, eontinuing a long time in use: vine very hardy and productive.

Early Victor-In bumel and herry it is rather below the average, but ripens very early, aud what is of special importance it is very pure in flavor, witl very little pulp and willont a trace of foxiness, or other unpleasant tastes, while it is exceptionally sweet, sprightly and vinous, never eracks and adheres firmly to the buneh. Very hardy,

and one of the few that resist mildew perfectly. Color black, witl a fine bloom
Eumelan-A native black grape. Bunclies above nedium, very handsome, double slonldered and moderately compact ; berries round or slightly oval; in size inedium; in color black. Its tlesli is tender to the very center; its thavor lich, vinous and spriglitly.

Green Mountain-Originated in Vermont. Vine ladrly, vigorous ant productive. l'ruit wlite, skin thin, pulp tencler and rieh ; ripens (iilly.

Hayes-I new white grape of medium sized bunel and berry ; of first rate quality and very early; foliage healthy; vine vigorous and very hardy.

Hartford Prolific-Bunches rather lirge; berries large, globular; color almost black, covered witl a beautiful liloon! ; flesh sweet and juicy. Ripens four or tive days before Coneord; valuable for its laardiness, abundant benring and early maturity

Highland-Black; bune! and berry very large and handisome; ripens with Catawba ; (1tulity very good, desirable where ever it will ripen.

Iona (1)r. Grant) - Bunches large, long, somewhat slionldered and loose; berries mediun, of a fine, clear wine color; skin thy, lesh tencler, without pul], will a brisk, sweet, vinous tlaror. Ripens about a wes after the 1)( litwite.

Ives-l'robably a seedling of the Isabella; barly and productive, but witl a tough, acill c'enter. 
Jefferson-Vine very vigorons, liardy and prodnctive; leaves large, thick, downy; buneh very large, often double shouldered, very compact; berries large, ronndish, oval, light red, with a thin lilac bloom; llesh meaty or solid, tender, juicy, sweet, slightly vinous, spicy ; best for market.

Jessica-White; originated in Canada; ripens with the earliest; small to medinm in bunch and berry; vine a fair, compact grower, hardy, healthy and prodnctive.

Jewell-Originated in Kausas ; similar in appearance to Early Victor ; ripens with the very earliest; black; bunch and berry medium sized, sweet, sprightly and good; vine vigorons, hardy, healthy and produetive.

Leader-Originated in Ohio; white; bunch and berry medium sized; will dry into raisins; quality good; very hardy and productive.

Lady $-A$ seedling of the Coneord. Of medium size, white and very good flavor; very early.

Lady Washington (Ricketts) - A cross between Concord and Ailen's Hybrid. Fruit yellow, tinged with piuk; bunches very large, often weigling a pound. Vine strong, very hardy.

Martha-A seedling of the Concord, which it resembles in growtli and hardiness. Buneh of good size, and berry large, of pale green or light color ; buttery, sweet, juicy, sprightly. Ripens with the Concord.

Mills-Black; originated in Canada. Vine vigorous, hardy and healthy; supposed to be a cross between a native and foreign variety ; bunch very large, long and should. cred ; berry medium to large, adheres firmly to the stem, flesh tirm, meaty, rich and sprightly.

Moyer-Red ; originated in Canada ; vine hardy, healthy and productive ; bunches and berries rather small ; ripens very early-with the earliest-and hangs well on the vine; resembies Delaware in appearance; sweet as soon as colored; skin thin but tough, pulp tender, rich and juicy.

Monroe-Bunch medium to large, shouldered; berries large, round; skiu rather thick, black, covered with a thick coating of white bloom, very handsome. Flesh juicy, sweet, vinous and sprightly; a pleasant, refreshing table grape, and it is believed will make good wine. The vine is vigorous, with fine, healthy foliage. Ripens with Hartford Prolific.

Moore's Diamond-Viue a vigorons grower, with dark liealthy foliage, entirely free from mildew. A prolific bearer ; bunches large, haudsome and compact, slightly shonldered ; color delicate, greenish white, with lich, ycllow tiuge when fully ripr: Skin snooth and free from specks; pulp tender, juicy, and nearly transparent, with very few seeds. Berry about the size of Coneord ; rich, sprightly and sweet. Ripens about two weeks before Concord.

Moore's Early-A seedling of Concord, combining great vigor, health and prodnctiveness ; ten days earlier than Hartford. In qnality, hardly to be distingnished from: Concord. Bunch large, berries very large, black.

Niagara-Originated in Lockport, N. Y., in 1868, and is a eross between the Concord and Cassidy, first fruiting in 1872. It has since regnlarly borne large erops of fine frnit. The vine is a remarkably strong grower and very hardy; the leaves are thick aud leathery and dark glossy green; bunehes very large and nniform and very eonpact; berries as large or larger than Concord and skin thin bnt tongh; quality gool, very little pulp, melting and sweet; ripens with the Concord.

Pocklington-1s a seedling of the Concord. Originated and raised from seed by John Pocklington, Washington County, N. I., an elevated, cold, late locality. '1he vine thoronghly hardy, both in wood and foliage. Strong grower; never mildews ; is a light golden yellow, clear, juicy and sweet to the center, with little or no pulp; bnuch very large, sometimes shouldered; berries round and very large and thickly set.

Woodruff Red-Branches and berries very large aud handsome, sweet and of fair quality, and strong and vigorons grower and iron-clad hardiness.

Wyoming Red-A very early red grape, desirable for the garden and vineyard, a good grower and healthy; bunch and berry small to medium, sweet, but a little foxy.

Winchell-Originated in Vermont. Color greenish white; bunch aud berry medinn size, Hesh tender, juicy and rich. Tine hardy and healthy; ripens very cirly.

Poughkeepsie Red-A seedling grape, raised by A. J. Caywood; said to be a cross of Iona with Delaware aud Walter; somewhat larger than Delaware, but resenbling it in general appearance. It is fully equal to the Delaware in quality, ripens carly, and keeps well. So far as tested, nuch like the Delaware vine in liabit of growth.

Prentiss-A seedling of the Isabella; buncli large, not often shouldered, compact; berry medium to large, jellowish to green, sometimes with rosy tint on side next to the sun; skin thin but very firm; thesh tender, sweet, melting, juicy, witl a very pleasant musky aroma ; viue a vigorons grower, with thick, heary foliage, aud very productive. 
Rebecca-A fine and delieions white grape, berry and bundr medium size; vine a slow. slender grower and abundant bearer; not quite hardy. Ripens almost as noon as the Delawarc.

Ulster Prolific-A niee native secdling. A red grape of good guality, heilthy growth and great productiveness. Will probably be found valuable for generall use, as it seems to have all the charateristices of our hardy and healthy native varieties.

Vergennes- I chance sechling foumd at Vergennes, Vt. Free from mildew : very jro luetive; (lusters large, berries large, holding firmly to the stems; color higlit amber, rich and dolicious, thesh meaty and tender. Ripens as 'arly ats I Iartford l'rolifie, and is an excellent late keeper.

Worden-A seedling of Concord, which it greatly resembles in appearanee and flavor, but the berries are larger. The fruit is said in he better flavorel, and to ripen several days earlicr.

\section{ROGERS' HYBRIDS.}

Agawam (No. 15)-large, roumd, early, and of trreat vigor of growth. Rich, high peculiar aronatie thasor.

Gathe (To. 1)- I tine lirht eolored variety, tinged and nearly covered with red when fully ripe. It has more the flavor of its foreign parent thain any of the ofhers, beine tender to the center. IBunch and berry large. Ripens w ihl ("atawha.

Lindley ( No. 9)-Resembles No. 3 in appearance, but distinct in flitror.

Massasoit (To, 3)-Large; resembles Diana in quality; a litlle matire flavor ; temler, sweet and good. Said to be the enrliest of these Hylrids, atul, by some highly estcenierl.

Merrimack (No. 19)-Very larre and eatier than the l)iann: repy strongly resembles No. 4. Berry and bunehes large, compaet ; a very strongr inrower.

Salem (No. 22)-Bunch large and compact ; berry lange, of a light (hestnut or Calawhat color, thick skinmed, nerfectly free from hard pulp; very sweet and sprightly, with a most expuisite arontatic tiavor: ats carly as the Delaware, laving never failed to ripen in the urost unfavorable season for the past six years: kiceps well

Vilder (No. 4)-laarge, bunches greatly shouldered; berry round and larege, flesh buttery, with a somewhat fibrous center, sweet, rather spightly.

\section{Dewberry or Running Blackberry.}

Lucretia-The plants are perfectly laddy and healthy, and remarkably produchive. The fruit, which ripens with the Hammoth Cluster laspberry, is often one and is Inalf inches long by one incli in diameter, soft, sweet and luseious tluoughout, wilhout any haril center or core. As the Inewbery rools only from the tips, and loxs not sprout like Blaekberries, this will be muelr nore desirable for gurlen cultures. aud the trailing lablit of the plant will render winter proteetion easily accomblisicel in coll climatc's where that preeation may be neecssary.

\section{IMPROVED DUUARF JUNEBERRY.}

The Inneberry is one of the most valuable beries. 'The wood is lourl and firm :url endures the ('xtremes of elimate withom injury, lis lenves are a dark, glossy green. The plant propagates from suckers. The flowers appear about the same time as those of the apple. 'The frut is borne in clusters, like the conran, and ripens in Junc. Its size eftuals the Wilil Gooseberry; shape, romel ; color, redrlish purple at tirst and becomes a bluish black when fully ripened. Its favor approaches the lluckleberry, a mild, very rich sub-acid. Perfectly harly, not being injured by wet, cold or elry weather, and needs 110 siperial treatment. 

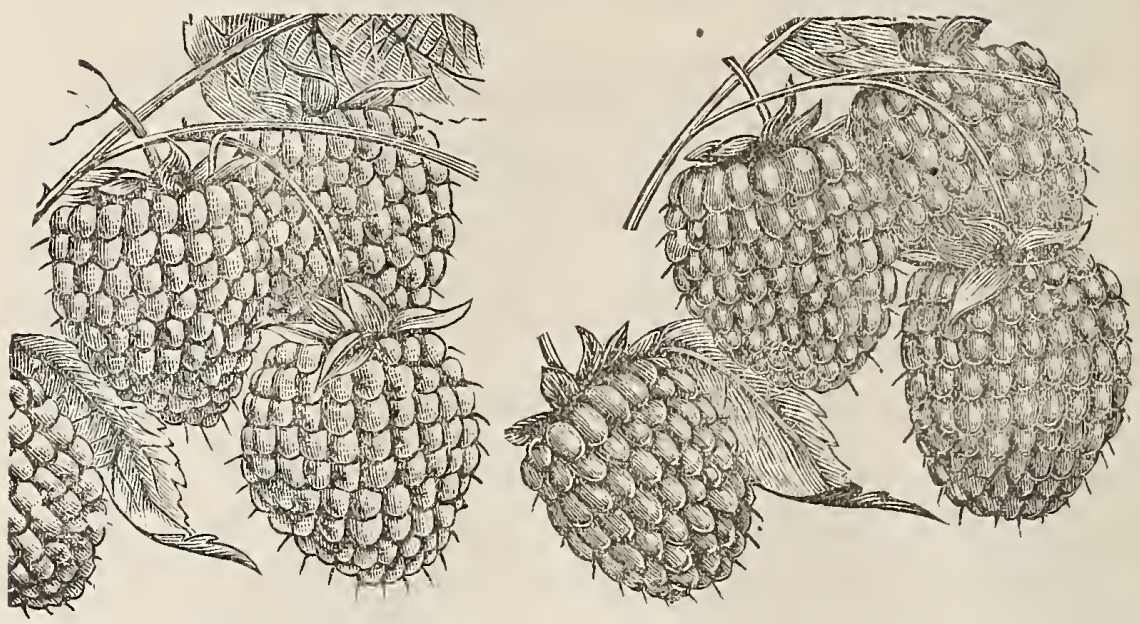

\section{SMALL FRUITS.}

The small fruits, such as Strawberries, Raspberries, Blackberries, Gooseberries, Currants, etc., ripening from the first of Jume till Fall, are everywhere capable of successful cultivation, and yield large returus at comparatively small expense. They shonld have a place in every garden. Since the introduction of self-sealing jars and caus, they ean be had throughout the year almost as fresh as when gathered.

\section{STRATUBERRIES.}

First of the Small Fruits in the month of June eomes the beautiful, wholesome and appetizing Strawberry. The protits which result from its cultivation, when properly conducted, are enough to satisfy the highest expectations.

Plint in Marcli, April, May, September, October, on good ground, deeply worked and well manured, Vegetable manure (muck, rotted turf, wood soil, ashes, etc.) is the best. Bone dust is cxcellent. Set in 3 feet rows, 15 inches apart in row for field culture, and 15 inclics each way for garden, lciving a pathway at every third row. Keep in hills with runners cut, unless troubled will the white grub. Cultivate clean, mulcl late in the Fall, uncover plants early in Spring, remove muleh after fruiting, and spade in liglit dressing of minme.

'Bidwell--One of the very best, abundantly produetive, full average size, exccllent flavor and one of the very earliest.

Big Bob-A fine variety for either market or private gardens. Fruit of large size and of good quality; ripens moderately early. It is a pistillate variety, requiring some other perfect flowering sort to be planted near it.

Bubach (P.)-Strong, rampant grower, like the Creseent, only making plants and foliage of tricc the size; healthy and free from rust; very productive of large, bright scarlet berries, rather soft, and of fair quality; ripens early, and succeeds either on light or heavy soil; a valuable market variety.

Captain Jack-Immense yielder; fruit medium to large, good flavor. Similar to the Wilson, but better flavor. It is a strong and luxuriant grower, healthy and produetive; berries large, landsome and solid.

Charles Downing - Large, conical, crimson; flesh firm, of fine flavor and good quality; plant healthy, vigorous and produetive. 
Cloud-A strong, vigorous grower, with leavy dark green foliage ; large size, bright red, firns; ripens carly. Pistillate.

Crawford-The plant is lage and stocky, usually free from rust; a luxuriant grower and an abundant bearer; blossom perfect, very strongly staminate; fruit very large and usually of regular form; first berries are sometimes slightly llattened or tringular, but never coxcomb or missliapen; it has a smooth surface and is of beautiful red color, ripening without white ends. The seeds are even with the surface or slightly raised ; this, with its firm flesl, enables it to endure landling and carrying with but little dimage.

Crescent Seedling-Medium, conical, bright scirlet, very uniform in size. $\Lambda$ beatiful bcrry, commencing to ripen witl Wilson's Albany, and continuing in fruit longer. The plants are wonderful in growtl, laking cntire possession of the ground to the exclusion of weeds and grass. It appears alike at lome on all soils.

Cumberland Triumph - I magnificent variety; berries immense; fine, perfect form, and of tine flavor Plant vigorous and productive.

Glendale-Is a late profitable market berry, this is the very best in many sectious; large, oblong-conic, scarlet, and very firm, .but rather aeid; a strong grower and procluctive

Gold (P.)-Recently introduced ly the Connecticut State Pomologist; plant lacks in vigor of growth; is fairly productive of medium to large size herries of very superior (fuality ; it is reported to be of great value on ricli clay soils.

Great American-Very large, sometincs 9 inclies in (ircumference. A vigorous grower ; tlesh firm; flavor tiuc; procluctive.

Haverland-Large, liealllyy, vigorous growing plant ; very productive; fruit large, conical, witl slight neck, uniform in size and shape; bright red; firm. Pistillate.

James Vick-An excedingly vigorous grower, folizge healthy and of a peculiar clark or blue-green color, very distinet perfect blossom ; fruit medium size and very uniform.

Jessie-Recently introduced from $1 /$ isconsin; plant a strong robust grower, siunilar to Sharpless. On moist soil it is a robust, liealthy plant: long stout fruit stalks liold the fruit well up from the ground ; berries of largest size, medium to dark red color atl the way througlı; firm and solid and of most excellent quality ; very few small berries and none of the largest oncs of irregular shape.

Jewell (P.) - I native of Connecticut; makes so few rummers that it is hard to propagate; when planted in rieh, deep soil, and given the lighest culture, they make wontrous big lills, and produce cnormous big crops of very large berries, of deep groxsy scarlet color, that make a most attractive appearance.

Kentucky-A native of Kentucky; very large, bright scarlet, sweet and delicious ripens abont a week bater than most varieties; fruit tirm ; a fine market sort; jlant liardy and very productive; valuable for the late malket.

Lenning's White-l'le best white variety. It is lighly perfumed and of exquisite (fuility, but not very prolific. Valued for preserving.

Mammoth - A fairly good plant on light soil and a strong and healthy grower on a (leep rich soil; jorluctive of very lirge berries. Some wonderful stories are told of enormous herries that liave been obtained from this variety the pat year, and it is likely to be planted by all who are striving for exhibition berries

Manchester-Size large, color scarlet, flesh pink, firm but melting, with \& rich, sub-acid juice, and a lecided aromatic flavor. Plant rolust and very productive; quality very gool to lest.

Miami-Origrinated in Ohio. Large to very large; rieh, lark red ; very solid and meaty; plint vigorous and produces plenty of bie berrios.

Old Iron Clad (Pliclps' Seedling)-Origin, Soutlem llinois. 'This is a strong grower, producing enornous stools ; foliage very large and licalthy, of a light creen color; the fruit is from large to very large; very firm; hright scarlet; of fine yuality, ind ripens early.

President Wilder-Large, conieal; scarlet; sweet, fine flavor, grood bearer. A rross between Ilovey's seedling and La Constante.

Sharpless-One of the best varieties. Large in size, delicious flavor ; good beurer, bright color.

Triomphe de Gand-Large, conical, often coxcombed : polished, sweet and fine tlanored. Does best on lecavy soils. A popular foreign variety.

Warfield (l') -Originated in Illinois. Vigorous grower, productive; ripens anly ; medium size.

Wilson's Albany-Large, conical, dark red, firm, hardy ; prolifie, lathor acidl. Succeeds every where. 


\section{RAsPberRIES.}

ihis iruit comes just after strawberries, and when properly cultivated is quite profitable.

Plant on strong soil, manure freely, eultivate well or mulch heavily. For tield, rows seven feet apart, four feet in row. Piuch off canes when three feet high, and prune off laterals the followiug spring, within twelve or eighteen inches of the cane; in garden culture, tie up to single wire. Cut out old wood each year. Cover tender varietics in Winter by bending down and throwing on earth.

Brandywine-A large, searlet lerry, firm and beautiful ; bears transportation well, but not quite equal to some others in quality.

Brinckle's Orange-Large, orange yellow ; high thavored, teuder and riel.

Caroline-Canes vigorous, prolific and quitc hardy, without protection. From its superior quality aud hardiuess, it is of great value for the home garden.

Clarke-A highly valuable sort, which has proved perfectly hardy. Busl a strong grower. Fruit large size, beautiful light scarlet, and of the most delicions flavor. Conmences to ripen with the earliest, and keeps in bearing till late in the Summer.

Crimson Beauty-Very large size, bright, glossy scarlet, round to oblong; earlier than the Turner, of a more pleasaut, sprightly flavor, equally as hardy, more produetive, and of much larger size.

Cuthbert-Perfectly lardy. The canes are tall and vigorous, and cnormously productive. Berries very large, conical ; rich crimson, very handsome, aud so firm that they can be shipped hundreas of miles by rail witnout injury. Flavor rich, luscious, best, commences to ripen moderately early, and holds out until all othcrs are gone.

Golden Queen-The finest flavored of all the Raspberries. In size, equal to Cuthbert; immensely produetive; a very strong grower, and hardy enough even for extreme Northern latitudes, having stood uniujured when the Cuthbert suffered. The desire for a ycllow raspberry of high quality, combiued with vigorous growth and perfect hardiness, is believed to be fully met in this variety.

Hansell-One of the very earliest and most desirable of Red Raspberries; color bright searlet; quality excellent; very productive, and fine shipper. Its great earliness causes it to bring the highest price in market.

Herstine-Plant a good grower, bears early and abundantly, hardy, and rery produetive ou all soils. Suckers moderately. Fruit large, firm, bright crimson, with small grains. Flavor sub-acid and very good.

Highland Hardy-Plants very hardy and thrifty; unusually productive; succeeds on most any soil, and ripens the fruit very early; bcrry good size, bright red aud sufficiently firm for shipping. Valuable for market.

Philadelphia-It is a stout, healthy grower, very hardy and inmensely productive. The fruit is of the largest size, aud presents a fine appearauce, even after it has been trimsported a long distance to market.

Rancocas-Very vigorous, throwing out numerous fruiting branches. lis productiveness cannot be excelled. As a shipper it is perfect, ripening with the enrliest; the color is a bright red ; size medimn to large; quality best.

Reliance-Produces berries of the largest sizc; color dark. Enormously productive; very desirable.

Scarlet Gem-A valuable cxtra early market sort. The plant, though not so stroug and stocky in its growth as the cuthbert, is far more vigorous than Hausell, Higlilaud Hardy, or any of the early varieties in culivatiou, fully as productive as Cuthbert, bright scarlet eolor, very firm and solid, and in 1888 ripened four days earlier than any of the leading extra carly Red Raspberries growing in the same field, less than two rods away.

Shaffer's Colossal-Colossal, both in bush and berry. Carries to market well; excellent to dry and unsurpassed for ennning. Berry dark crimson in color and excellent in quality; a very valuable variety. Does not sucker, but roots from tips like Black Caps.

Marıboro-Large size, light erimson color ; good quality and firm. Plant vigorous and productive. The first berries ripen quite early, but the cutire crop covers a period of four or five weeks in ripening.

Turner-A. beautiful red berry of fine size aud excellent quality; said to be the hardiest and most produetive variety known. 


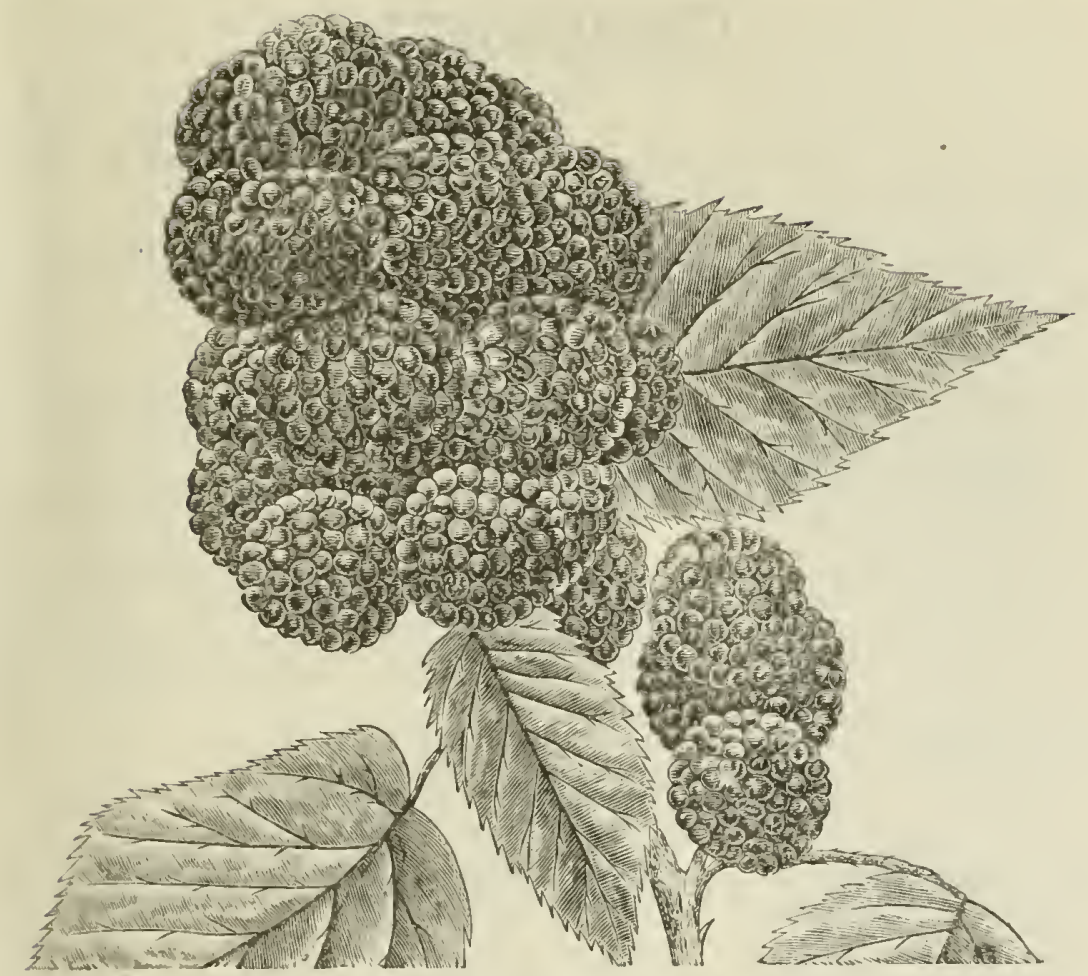

BLACK CAPS.

Carman-liesembles the souhegan in growth ; i igorous, healthy and hardy ; productive, jet black and firm ; very early.

Earhart-Strong, stocky crower, with an alumdance of stout, heary spines; very lardy; frult of large si\%, jet black and of good quality, commencing to ripen carly and (ontinues till stopped loy freering in the Autumit.

Gregg-'This is decidedly the largest Black Calp that we have erer seen, far surpaning in size the famous Limmotle Cluster, averaging, when grown side by side, with the sime treatment, from one-third to one-linlf larger:

Johnston's Sweet-This is the sweetest Rimplocrry grown. It.takes less sugal either for the table or for canning or evaporating, than any other se:t. The flavor is deli. ('ious. It is a great bearer; nearly equal in size to Gregg.

Mammoth Cluster (AIcCornick)-The bush is a strnig, mpight grower ; foliage a rich. dark green ; fruit large, and holds out largere to the very list pieking; black, with a rich purplish bloons ; very juicy, ligh flavored and dehcious; perfectly hardy, the surface sufliciently firm to bear transportation to distant matrkets.

Ohio-The greatest producer antong l3lack Caps, and for camning or evaporating clainesl (1) be the most profitable of all sorts. Perry not cunite as laree as Gregg, but finer Ifuality and the plants more lrarly and will bear more successive crops.

Hilborn-A large liack Cinp, recommended for its sime and quality. Rijens carly.

Souhegan-1 variety of the now positive value, of excellent yuality, about as large ats an the Gregg, and antonishingly prolitic, exceding in this respect any liapberry known. I perfect ironclad in liardiness and extrencly (arly, at least two weckis eatrlier than the Inolittle. It has every indication of loeing the most desirable I3laxck lisisperry yet produced.

Tyler-.I variety of undoulterl merit. F'ruit of best quality and a very prolitic lsatrer. 


\section{CURRANTS.}

This fruit comes partly with the Raspberry, but follows it several weeks. Indeed, none of the small fruits will remain so long upon the bushes without injury as the Currant. An easy method of destroying the currant worm is by the use of powdered white hellebore (Veratrum Album).

Set four fect apart in rich ground ; cuitivate well or mulch heavily ; prune out old wood, so that each remaining shoot will have room to grow; if the currant worm appears dust with hellebore every threc weeks. Manure freely.

Black Naples-Very large, sometimes measuring lalf an inch in dianeter. Fine for wine or jellics.

Black Champion-Bunches are very large, and the flavor of the fruit particularly delisous. It liangs long on the bushes, and unlike other varieties it will bear the severest pruning witlont detriment.

Cherry-The largest of all the red currants. Berrics sometimes more than half an inch in diameter ; bunches short, plant very vigorous and productive when grown on good soil and weil cultivated.

Crandall-Originated in Kansas. In form of bush similar to our common currants, but making a stronger growth; fruit bluish black, and in size from $\frac{1}{4}$ to $\frac{3}{4}$ inch in diameter : has a distinct flavor, desirable for pies, etc.

Fay's Prolific-Color deep red; great bearer; stems longer than cherry, and berries hold their size to the cnd of the stem better. Quality first-class; not quite so acid as cherry, the best of all the red currants.

La Versaillaise-Very large, red; bunch long, of great bcauty and excellent quality; one of the fincst and best, and should be in every collection.

Lee's Prolific-An English production of great value. The fruit is large and of superior quality; the bush is a vigorous grower and enormously productive, rendering it very profitable.

Moore's Ruby-Originated near Rochester, by Jacob Moore. Berries about same size and color of Victoria; bunches are long, bushes vigorous and very productive; less acid than the cherry.

Prince Albert-Largc, bright red, rescmbling the Victoria; valuable for its latcness; vigorous and productive.

Red Dutch-An old varicty, excellent and well known.

Victoria-Large, bright red, with very long bunches; late, a good bearer. Very desirable.

White Dutch-An excellent and well known sort.

White Grape-Very large, yellowish white, sweet, or very mild acid, excellent yuality and raluable for the tablc. The finest of the white sorts. Very distinct from White Dutch, having a low spreading habit and dark green foliage. Very productive.

White Gondoin-A large, light-colored sort, sweet, vigorous and productive.

\section{Gooseberries.}

This fruit requires the same cultivation as the currant. The surest method to prevent mildew is to plant thickly in the rows, and mulch deeply, six or more inches with straw, tan bark, coal ashes, etc. Plantations thus treated have borne large crops for 20 years. The mulch retains moisture in the dryest weather; the few wceds that push up are easily pulled, and the fruit is large and more evenly ripened. In mulching be sure the ground is UNDER-DRALNED, or it is worse than uscless. Good cultivation is better than nalw mulching. Put it on thick. In a dry season the extra amount of fruit will doubly pay for the material used, not to speak of the saving of labor and cleanliness of the fruit. The price is remunerative, and the demand is yearly increasing. The Anerican varietics are not subject to mildew.

\section{ENGLISH VARIETIES.}

The number of varieties of English Gooseberries is almost innumerable. 'The fruit is generally large and handsome. The best sorts are InDustry, Crown Bow (red), and WIITE SHIn (greenish white), which in favorable localities do extremely we?.

Crown Bob-Fruit large, oblong, lairy ; flavor first class. 
Industry-It is of rigorous, upright growth; a larger eropper than any other known variety, and one of the best for market purposes, owing to the properties it possesses of tlowering late and afterwards swelling so quiekly as to reach a suitable size for pulling green sooner than any other variety, If left to at tain maturity it is a dark red eolor, hairy, with a pleasant, rieh flavor.

White Smith-Fruit large, roundish oblong; flavor tirst rate.

\section{AMERICAN VARIETIES.}

Downing-Origin, Newburg, N. Y. Fruit large, roundish, light green, with distinct $\checkmark$ reins; skin smooth, flesh rather soft, juiey and very good. Vigorous and productive.

Houghton's Seedling-A mediumsized Ameriean variety, which hears abundant and regular erops, and never mildews; fruit smooth, red, tender and very good ; very valuable.

Large Golden Prolific-Is a decided acenuisition to the smali list of hardy, mildew-proof Imeriean Gooseberries. The variety is at remalrkably strong, vigorous, upright grower, with dark green glatucous foliage, which resists nuldew perfectly, and persistently hangs on until the end of the season. The fruit is of the largest size, oblong, good samples measuring $1_{1}^{3}$ inches in length. Color golden yellow, flavor deeidedly good : very productive.

Mountain Seedling - I strong grower and heavy beatrer; berries very large, dark red. smooth; a profitable variety.

Smith's Improved-From Vormont. latrge, oval, light green, with bloom; tlesh morl(rately firm, sweet and good. Vigorons grower.

\section{BLACKBERRIES.}

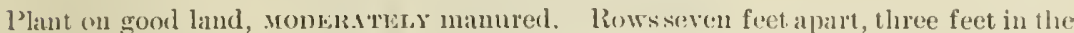
rows for tield; prune as with Raspberries. Form a hedge or tie to wire. ('nltivate N11LLLOOW.

Agawam-Ripens earlier. than other linds, ame llats at flavol similar and "qual to the wild berry. Perfeetly lardy.

Early Harvest-A variety of great promise, being exceedingly early in time of ripening and always reliable. The eanes are strong and upright in growth, branching stout and vigorously. IIardier than littatinny or. Lawtou; an enormons bearer. Berries sweet and of the highest quality, though not as large as sone varieties.

Erie - Fery large und wry curly. Perfectly hardy, a stiong grower and great bearer. producing larger, sweeter berries, earlier in ripening than any other sort.

Freed-Originated in Ohio. Very hardy; immensely produetive, and has never loeen known to rust.

Kittatinny-Commences to ripen after the Wilson's Early, and continues longer in bearing; is ripe as soon as black, and much earlier, sweeter" and better in all respeets than the Lawton, which it resenbles in plant ancl fruit.

Lawton-Fruit very large and black, of excellent quallyy ; an abmundant bearer,

Minnewaska-Perfectly hardy, very produetive and a vigorous grower; very carly.

Snyder-Extremely hardy, enormously productive, medium size; no harr, sour (o)re: half as many thorns as Iawton or Fittatimny, and they are nearly straight and short. Wo:t prolitic blacklecry grown.

Taylor-One of the largest blackberries grown. Fruit of the best quality, melting and without core; very productive and hirrly.

Wilson's Early-Of good si\%e, very early, beautiful dark color ; of a sweet, excellent Havor and very productive. Ripens the whole crop nearly together.

Wilson Junior-A secedling of Wilson's Early, ripening a week carlior tham that viriety; fruit of the largest size; bush vigorous and healthy.

Wachusett Thornless-Fruit of medium size, oblong, oral, moderatcly tirm, sweet and good, and iess actil than any blacklocrry we have seen. It is a good keeper. ships well. and is therefore valuable as a norket berry. 'The plant is sain to do equally well on light and heary solls, and to bear heary erops where ofler varieties have failed. It is also very hardy, and fre firm thiorn. 


\section{MULBERRIES.}

The Miulberry is a very ornamental tree in garden or lawn, with its large, green glossy foliage; and some newer varieties are worthy of gencral cultivation for their fruit alone.

Downing's Everbearing-Produced from seeds of the Multicaulis. Tree very vigorous aud productive, continuing iu bearing a long time : fruit $1 \frac{1}{4}$ inches long and $\frac{3}{8}$ of an inch iu diametcr; eolor blue blaek, flesh juicy, rich, sugary, witl sprightly vinous flavor.

New American-Fruit of the largest size, black, delicious in flavor. An attractive lawn tree, with very large leaves; of rapid growth, hardy.

White-Commonly cultivated for silk. Fruit not equal to the black sorts.

Russian-Brouglit to notiee by the Mennonite colonists of the Northwest. The timber is desirable for fuel, is fine for cabinet work, and feuce posts made from it are exccedingly durablc. Is a rapid growing tree, bears fruit at two or three years of age, and every year; color of the fruit varies some, but is geuerally black ; valuable in Northern sections.

\section{Rhubarb or pie plant.}

This affords the earliest material for pies and tarts; eontinues long iu use and is valuable for canning. Make the border very rich and deep; needs higl eulture.

Early Scarlet-Rather small, but early and good.

Linnæus-Large, early, tender and fine. Tlie very best of all.

\section{Asparagus.}

To make a good Asparagus bed, the plants may bc sct in the fall or early spring. Prepare a picee of fine, loamy soil, to which has been arlded a liberal dressing of good manure. Select two-year, or strong oue-year plants; and for a garden, set in rows 18 to 20 inehes apart, with plants 10 to 12 inches in a row.

Make a small mouud of the soil, over which the roots should be evenly spread, so that the crowns, when covered, shall be thrce inches below the surfaee of the grouud. If planted in the fall, the whole bed should be covered bcfore winter sets in with two or three inehes of stable manure, which may be lightly forked in between the rows as soon as the ground is softencd in the spring.

\section{Nuts and Miscellaneors Fruits.}

Aimond, Soft Shell-This is the "Ladies' Almond" of the shops, and although preferable to the former, is not quite so hardy, Keruel sweet and rich.

Butternut- I native species, the Julgans Cinerea of botanists. Wood light color. Tree handsome.

Shestnut, American-Our native species. Smaller than Spanish, but sweeter.

Chestnut, Spanish-A hardy tree, producing nuts of very large size and good flavor.

Figs-Black Ischia, Brown 'Turkey, Celestial and White Narseilles.

Filbert, American-Snaller and with a thicker shell than the Euglish, but of good flavor ; hardy and productive.

Filbert, English-'The fruit of these is so much larger and better than our native species. as to give them the preference for cultivatiou over the latter, in localities where they will succeed.

Oranges and Lemons-Several varicties.

Walnut, Shell-bark-Our trees are grown from extra fine thin-shelled nuts.

Walnut, Black-The well-kuowi native species, hardy, prolific aud valuable. The timber in point of durability is diflicult to excel.

Walnut, English-This rich and fine-thavored nut is quite hardy with us, and malies it vigorous growth. Well worthy of eultivation. 



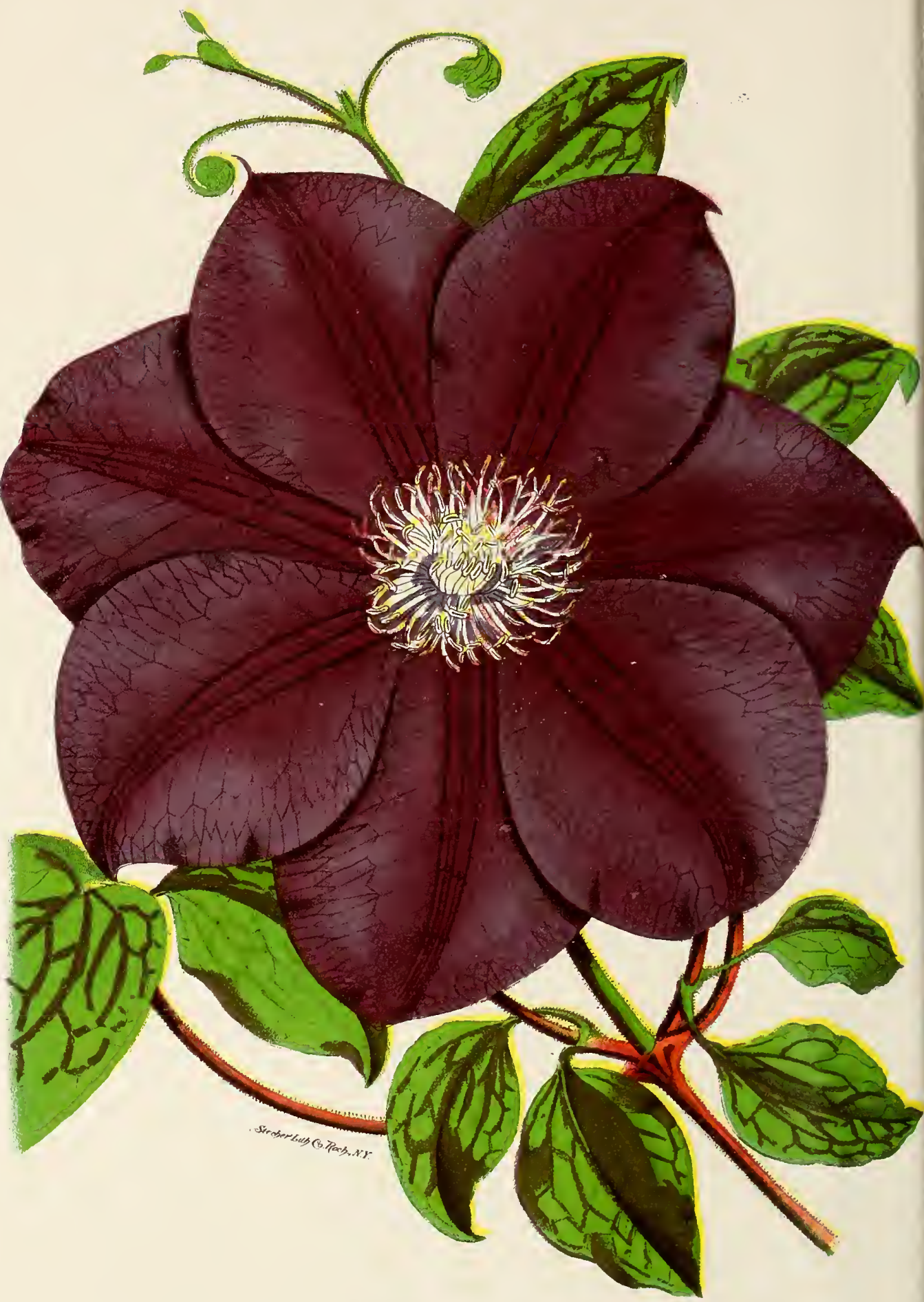

CLEMATIS JACKMANII.

Now well known and justly appreciated as one of the best of the many varieties of this popular hardy climbing plant. 


\section{Ornamental Department.}

\section{GENERAL REMARKS.}

The people in this country have scarcels hegun to rall\%" the comm(reial value of an investment of a few dollars julliciously expended in a few Ornantental Trees and Plants to onr homes Many of onr most active business nen ale also nen of taste, and would be glan to inprove and beautify theil grounds, but they are so occupied with business that they have neither the time nor disposition to fincl

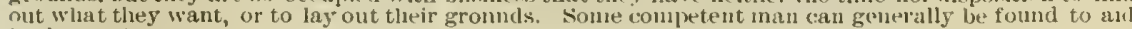
in the siatter.

Wind breaks of trees. more especially if they are evergreen. make the dweiling-house warmer. give comfort to is innates, diminishing to no incousiderable extenc the cousumptiou of fuel : they unate the ont building walner for stock by night, and the yard by day, not only makiug the dumb animals romfortable, hut thertby saving a läge anount of fool.

\section{HOW TO PLANT, \&c.}

Grass and trees are alwars charmino, and need but little cares in the laviur out and planting have regard to economy of labor. Lee there he as few walks as possible: : cut your flower beds (not many in the turf, and don't make the lawn a clecker. hoard of trees anel shruls. Mass then in boundary lines or in groups. leaving a hioal expanse of green for tine eye to rest on, and the nower to sweep freely over. It an uupleasant object is in sight conceal it hy planting free-giowing tret's ; if tnere is a pretty view leave an opeuing. While it is not well to have large trees near the house, there shouhl lut at lea-t one by the sumuy corner for summer shade. Plant towering shrubs aud the sinaller evergreen. in circles or ovals, and twiee as thick or close as they should stand when fully grown. This will nuakt a show at once, and in two year's or more you can take out one half, leaving the rest til fill out tlu space, and obtaining a supply of thely-rooted plants to set somewhere else. Where the ground is wholly given np to trees and shrubs, it should be deeply and thoroughly rrepared befort planing. Keep the earth cultivated, and the shrubs and trees mulcled the first two seasins, and then let tle turf grow about then. Jow the grass frequ+ntly, ald top dress with fine manure evely Fall aud linter.

Straggling growers, like the Forsthia and I'yrus Japonica, may he repeatedly pinched back on clippes during the growing season, to produce a close, compact form. Weigelas and Inutyias slumld be prnned back each year to the old wool. A very beautifil liedge can be made by interningling different Flowering Nhruhs, and elipping, or allowing then to grow natninly.

\section{TREES, SHRUBS, ETC., FOR ORNAMENT.}

A detailed description of desirable trees and slurubs wonld he little less than a recapitulation or lint contained in our catalogne of Ornamentals, to which reader's ar. referrel. A grouping together according to the times of flowering or size of growth will, however, be fomnd useful. We would suggest the following as anong the inost desirable

Flowering Shrubs. Altleas, blue, purple, led, white, pink and variegated. Almond, pink aul

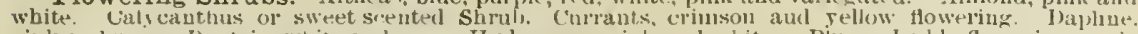
pink and rose. Dentzia. White and rose. Iydringer, jink and white. Plum, Iomble-flowering p nk. Japan Quince, red and white. Spirens, white and rose. Syringa white. Sirowlull wbite. vihn'mun Plicatum, white. Weigelia, rose and whit".

Flowering Trees. Magnolia, white and puplt. Julas Tree, pink. Peach. pink and whitt. Laburum, yelluw. Fringe Tree, whice and purple. IJomesuckls Tartarian, red and white. Stranbery Tree, red and white. Holse Clestnut. rel aml white. Cherry. white. Catalpa, white and punple. Thorns, pink, scarlet, red and whit:. Cornus Florida. white and pink.

Cut-Leaved Trees. Imperial Cnt-Leaved Ahler. Fern-Leaved Besch, ('nt-Ieaved Birch, Weir's Cut-Leaved saple.

Purple-Leaved Trees and Shrubs. Purple-l,avel Beceh, P'urple-leaved Berbetrs, Purjl

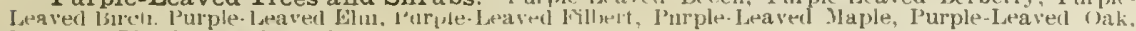
J'arple or Blookl-Linvind l'each.

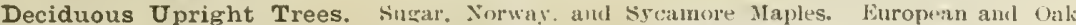

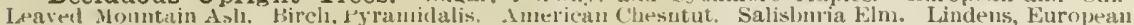
ald While-Leaved.

Variegated-Leaved Trees and Shrubs. Varicrated-Iterved Alder, Variegated-Iteaved Cormus, Variegated-Leaved Deutia, Variegated Honeysuckle, Variegated-Leaved Weigela, etc:

Weeping Trees. Willow, Kilmamock; Birch, Cut-leaverl Weeping, Elegans, P'tndula, arl

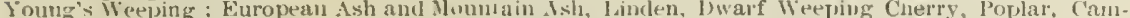
perrlown klim, Weejoing Cornus, aud Weeping Malb*rry.

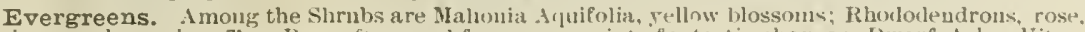

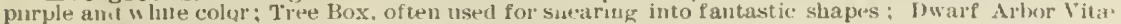
Dwalf or ILountain Pine, hajdy and fin' colored.

The Norway Spruce and Amprican Arbor Vitie are the lest know of Evergrens. Either as siugle trees or in helges the* are inclispensable. The Jlack and White Sprice vary in shate of eolor as their names inclicate. The White l'iue, light and graceful in its foliage: the Scotch, angular, sprealing, 
irregular, but finely colored; and the Austrian, erect, regular in growth, and bearing upright iones; are well known and desirable. 'The Balsam Fir is handsome, but loses its foliage-a fatal defect iu an evergreen,. The Siberian Arbor Vitæe is au improvement on the common Ainerican, for its strong, thick-leaved foljage. The Golden Arbor Vitæ may also be anded. The Irish and Swedish Junipers are compact cones of foliage (the latter light in color), and contrast finely with the round topped trees.

\section{HEDGES.}

The idea of planting hedges for use and ornament, and screens for the protection of orchards, farms and gardens, is a practical one. and rapidly becoming appreciated. They serve not only as protection against the fierce winds. but there is much less trouble from the blowing off of the fruit. Some writers tell us that the temperature is warmer in the vicinity of Evergreens. However this maj be, we know that our gardens are earlier, and that our fruits ripen better when protected by such screens. Nothing can be more beautiful than ornamental hedges of Evergreens or Shrubs well kept and pruned to serve as boundary lines between neighbors, or as divisions between the lawn and garden. or to bide unsightly places. We all know that such hedges continue a principal attraction in our best kept places.

\section{Decibuous TREes.}

Ailantus (Celestial Tree).

GLANDULOSA-From Japau. A lofty, rapid-growiug tree, with long, elegant, feathery foliage ; exempt from all diseases and inseets. One of the most distinct and ornamental trees with pinnate foliage.

Aider (Alnus).

EUROPEAN (Glutinosa)-A tree of rapid growth, suitable for damp soils, but thriving well everywhere.

IMPERIAL CUT-LEAVED (Laciniata Imperiulis)- A very striking and beautiful tree, with delicate and beautiful eut leaves; lardy and of vigorous growth; one of the finest cut-leaved trees in eultivation.

Apple (Malus).

CHINESE DOUBLE FLOWERING (Spectabilis)-Very showy and ornamental; beautiful double rose-eolored flowers.

Ash (Fraxinus).

AMERICAN WHITE-A rapid growing native tree, valuable for planting on the street or in parks; may be extensively planted for timber; largely used in the manufaeture of agrieultural implements.

EUROPEAN (Excelsior)-A lofty tree with pinnate foliage and spreading head.

GOLD BARKED (Aurea) -Growth irregular : very ornamental in Winter.

FLOWERING (Ornus Europaus) - A very ornamental dwarf tree ; flower fringelike, greenish white, early in June ; in large elusters on the end of the brauehes.

WILLOW LEAVED (Salicifolia)-A rapid, stout-growing tree, with narrow, wavy leaves ; very ornamental.

AUCUBA-LEAVED (Aucubafolia)-A fine tree with gold blotched leaves.

Beech (Fagus).

LACINIATA (Cut-Leaved)-Foliage deep and finely eut.

PURPLE-LEAVED (Purpurea)-A remarkable speeies with deep purple foliage, ehanging to greenish purple in Autumn. A very strikiug contrast with other ornamental trees.

FERN-LEAVED (Iteterophylla)-Of elegaut round habit, and delicately cut, fernlike foliage. One of the finest lawn trees.

Birch (Betula).

PURPLE-LEAVED (Folis Purpuris)-A very desirable novelty. With the labis of the Birehes it has beautiful purple foliage, as dark as that of the Purple Beceh.

PYRANIIDALIS-Silvery white bark, with elegaut pyramidal habit. Like Lom. bardy Poplar.

\section{Butternut.}

A native tree, of medium size, spreading limbs, grayish-eolored bark, ant foliage resembling that of the Ailantus. Nut oblong and rough. 


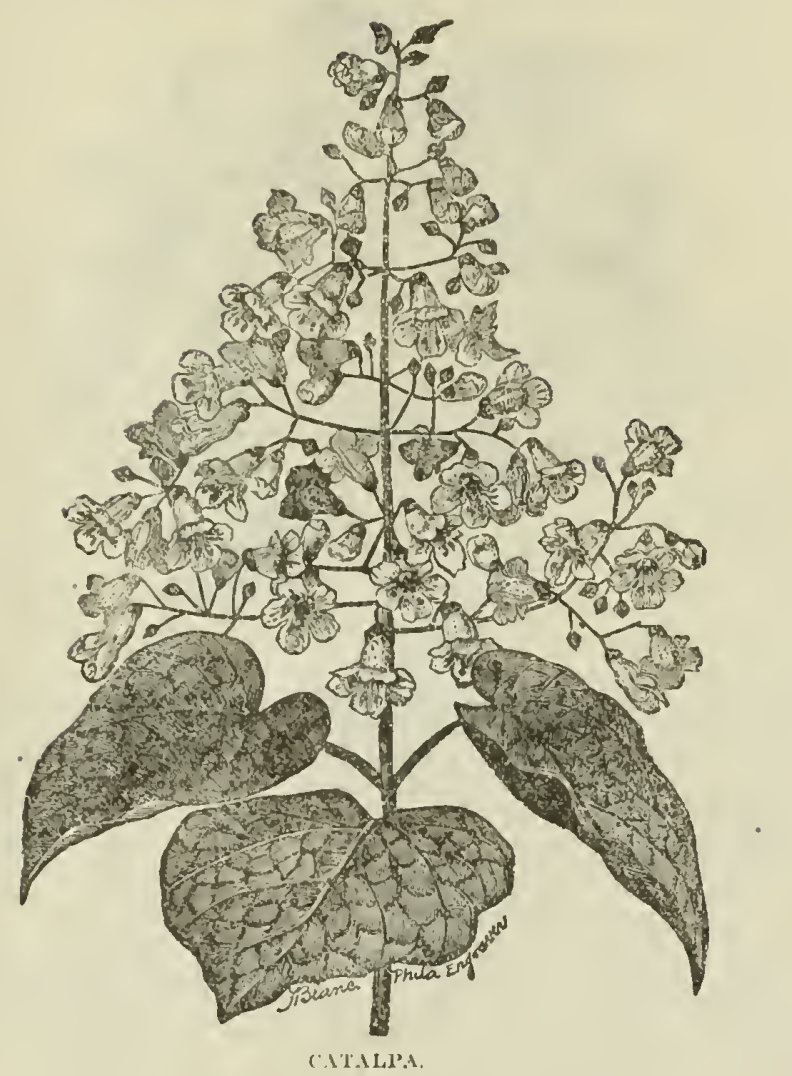

Ciesalpa.

SPFCIOSA - A variety origrinating at the West ; more upriglit and symmetrical iu its growth than the common Citalpa, and blossoms two or three weeks carlier. Very valuable fol timber, fence posts, rallroad ties, ete., possessing wonderlul durability. A very ormamental and valuable tree.

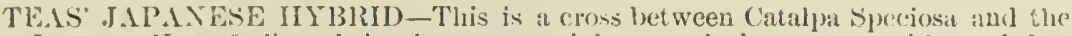
Japanese Fempferii, and, in vigorous, upright growtl, it surpasses either. It has large, luxuritut foliage, and large, handsone white flowers, with purple dots, ant a touch of yellow around the throat, which have a pleasant, delicate fragrance, and a tree in blom not only presents a magnificent spectacle to the eye, but also fills the air for quite a distance with its agreeable odors. In ripidity of growtl, it rivals the most luxuriant trees of temperate climates, while its hardiness has been demonstrated by its standing uninjured twenty-five degrees or more below zeros.

\section{Cornus.}

FLORIJ)A (Whiteflarering Dogrooart)- In Anerican species of fine form, growing from 16 to 25 feet ligh. The flowers produced in Spring before the leaves alppestr, are from three to three and a half inches in dianeter, white and very slowy. 'Tliey berin to : maintaining a succession of bloom in the garden border on the lawn. Fhey are also very durable, lasting in favorable wealler more than two weeks.

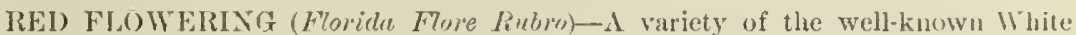
Dogwood, but Laving a deep rosy pink-colored flower. The leaves also have a soft, velvety appearance, and are of a darker ereen than the old variety. It makes a good, upright, bushy growth. 


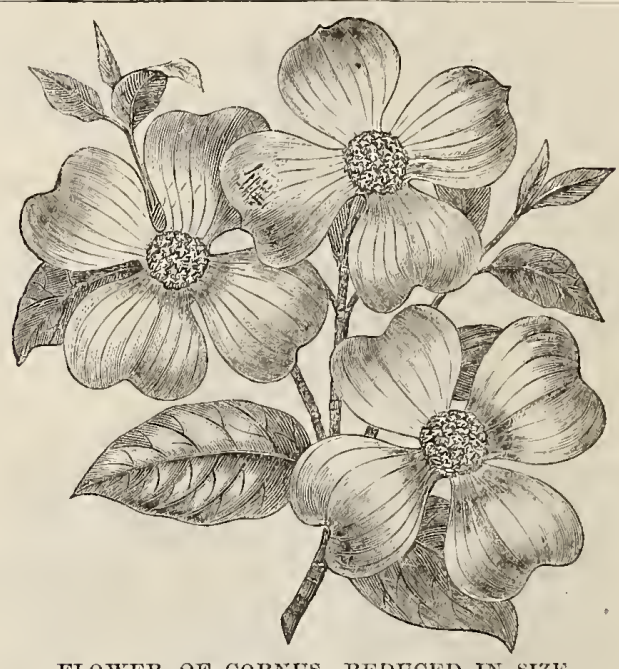

Chestnut (Castanea,)

FLOWER OF CORNUS, REDUCED IN RIZL.

AMIERICAN SWEET (vesc $\alpha$ )-Among our large colleetion of ornamental native forest trees, the Cliestnut is unrivalled for its beauty. When grown in the open ground, it assumes an elegant symmetrieal form. The foliage is rich, glossy and healthy, and the whole tree is eovered in early summer with long, pendant, tassellike blossoms, than whieh there is none more graceful and beautiful. It is espeeially dessirable for its nuts, which it bears profusely a few years after transplanting. The Chestuut thives well on any soil except a wet one. When nursers grown, bears transplanting well, and when once established is a lapid grower, and soon eomes into bearing.

JAPANESE SWEET, or GIANT-Of the very many good things introduced from Japan none are more worthy than this. The tree is decidedly ornamental, very hardy and productive ; of dwarf habit, bearing extremely young. Nuts of enormois size, and of the sweei, rich flavor of the American Chestnut.

Cherry (Cerasus).

CHINESE, or DW $\triangle R F$ WHITE FLOWERING (Sinensis $f$. $\mu$.) - $\lambda$ variety of the Morello with doulle white flowers.

FLORE ALBA PLENU (Large Double Flowering Cherry)-At the period of flowering a remarkably beautiful and attraetive tree. The flowers are so numerous as to eoneeal the branches, and present to the cje nothing but a mass of bloom, each flower resembling a miniature white rose. A valuabie variety deserving of wide dissemination. NIay.

Elm (Clmus).

AMERICAN WHITE (Americana)-The noble, drooping, spreading tree of our own woods. One of the grandest of park or street trees.

CAMPESTRIS (English)-Mlore upright and compact habit than Amcriean ; also, the leaves are smaller and more numerous.

PURPLE- A heautiful variety; leaves of rich purple color when young.

SCOTCH or WYCH (Montana)-A tine spreading tree of rapid growth; foliage large.

SUBROSA (Cork-barked)-Bark becomes covered with a fine, dense cork, with lcep fissures.

Honey Locust.

THREE THORNED ACACIA (Gleditschia Triacanthos)- I rapid growing tree; delieate foliage, of a beautiful, fiesh, lively green, and strong thorns. MIkes an exeedingly handsome, impenetrable and valuable hedge.

Horse Chestnut (Asculus).

DOUBLE WIITE ( $A l b a$ Plena)-A superb variety with large spikes of handsome, double flowers.

COMLMON or WHITE FLOWERING (Mippocastanum) - $\mathrm{A}$ very beautiful, wellknown tree, with round, dense head, dark green foliage, and an abundance of showy flowers in early spring.

RED FLOIVEP NG (Rubicunda)-Not so rapid a grower as the white ; foliage of a deep green, and biooms later. A very showy tree. 


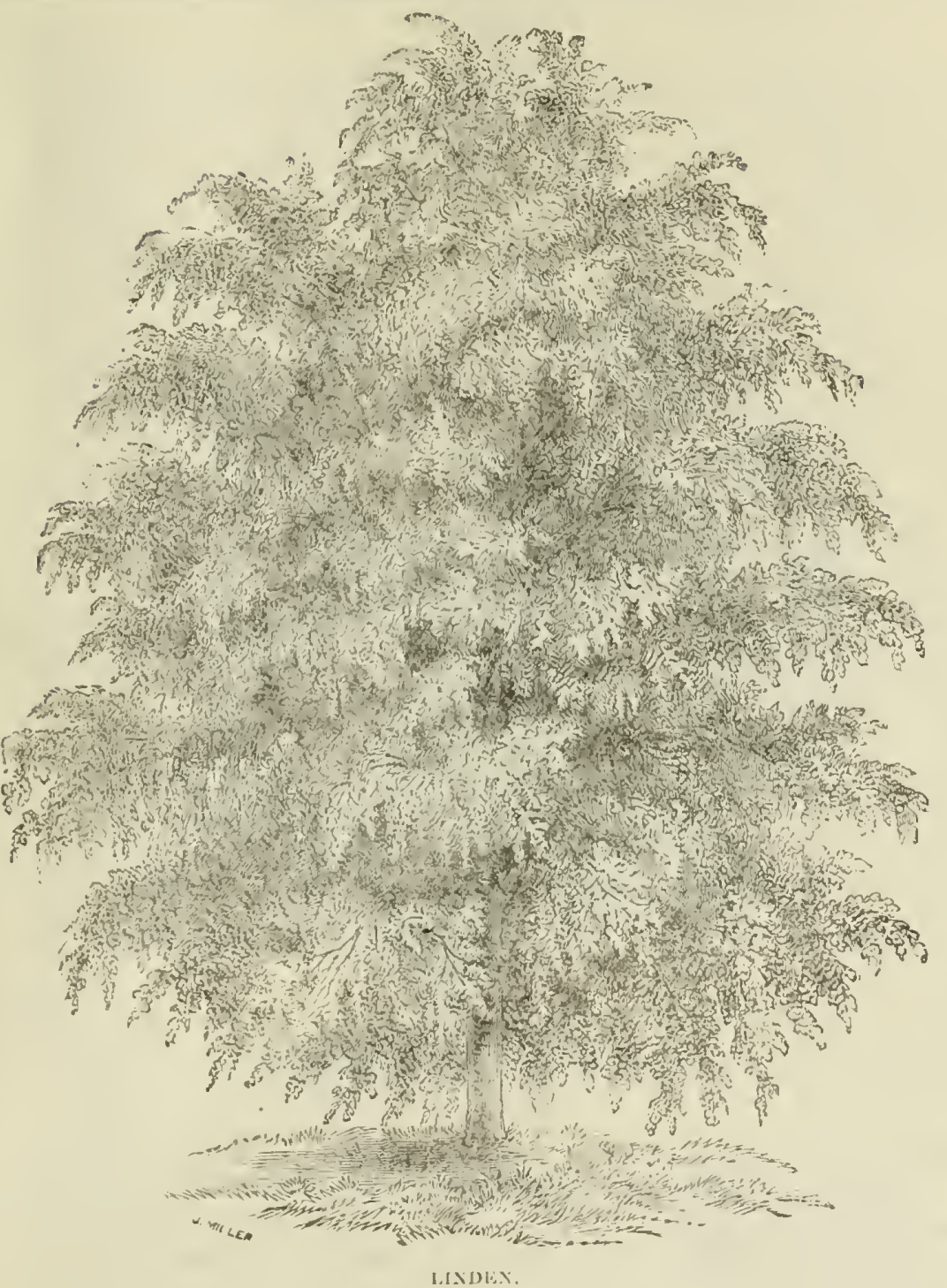

Horse Chestnut, Smooth Fruited (Pavia).

RED FLOWERING (Rubu)- $\Lambda$ small sized tree, with lark red flowers. I vers crooked and irregular grower.

YELl,OW Fl,OWERING (Flate)-Has pale green leaves, and shory yellow tlowers. A fine, small tree. 1 crooked and irrernlar grower.

\section{Hop Tree.}

TRIFOLIATA-A large shrub or suall tree, of rapid growth and robust habit. Fruit wiuged and in clusters. Flowers in Jume.

\section{Hornbeam.}

AIERIC IN.L (American Flornbeam) - I native species, rrowing from tifteen w twenty feet hirh In its mole of arowth, quite similar to the Besels, but the foliage is thimer and more irregulat in form. Makes a very ormanemal and useful herlge. 


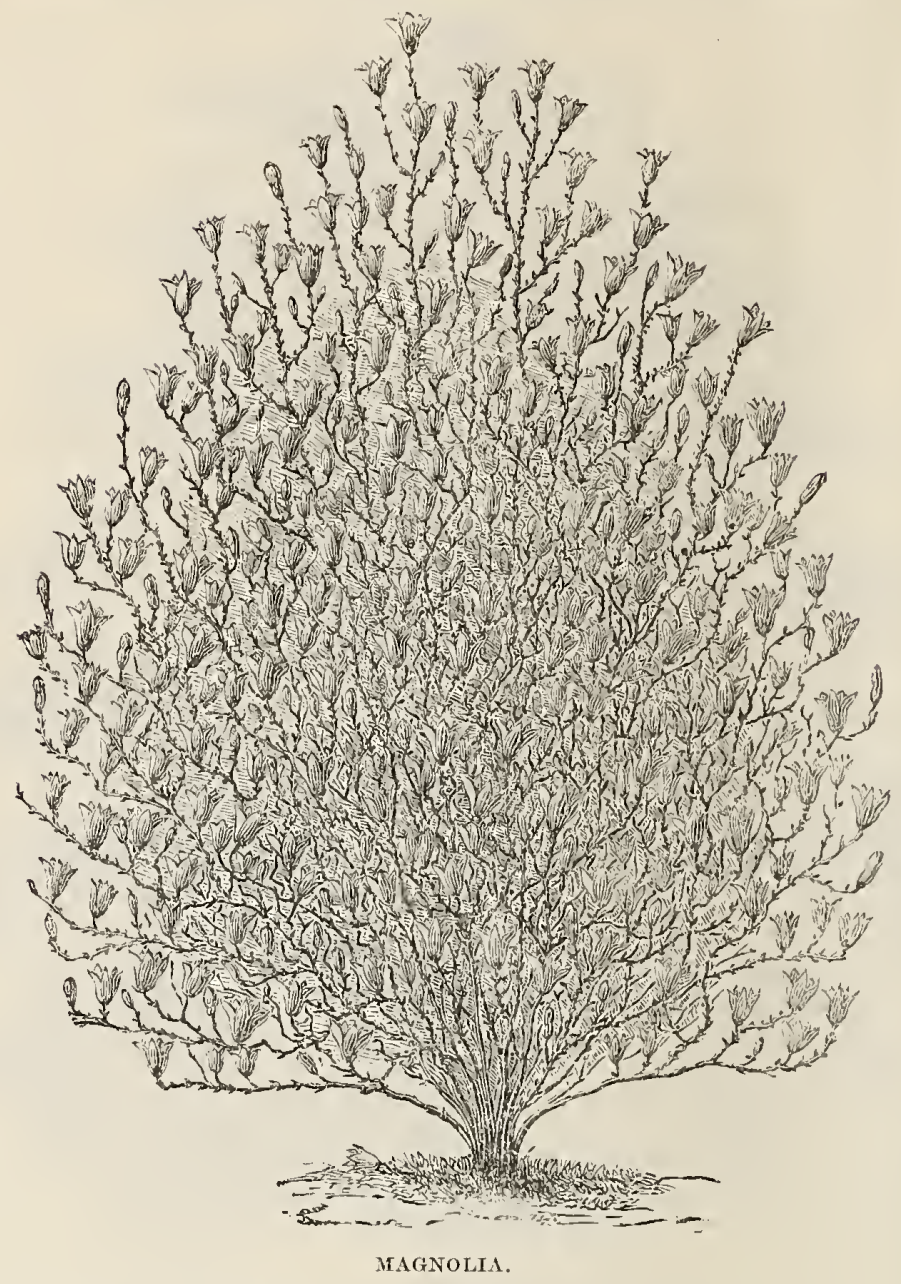

Judas Tree (Cercis). Red Bud.

AMERICAN (Canadensis) - A small growing tree, covered with delicate purple Howers before the leaves appear.

\section{Laburnum.}

COMMUNIS (Golden Chain)_A small tree of irregular sliape; bears lons, pendent racemes of yellow flowers.

Larch (Larix).

EUROPEAN (Europore)-An excellent, rapid growing, pyramidal tree; also valu. able for timber. Small branches drooping.

Linden (Tilia).

WHITE or SILVER LEA VED (Argentex)-A handsome, vigorous growing tree; large leaves whitish on the under side, and having a beantiful appearanee when ruthed by the wind. One of the best.

EUROPEAN (Europoer) - A pyramiclial tree, with large leaves and fragrant flowers.

RUBRA (Red-Twigged Europen Linden)-A fine variety with blood red branches.

AMERICAN Or BASSWOOD (Americam - A rapid growing, beautiful native tree, with very large leaves and fragrant flowers.

Liquid Amber.

STYRACIFIUA (Sicet Gum or Bilsted)-A tine native oranmental iree. The foliage resembles that of the Maple, and ehanges to a bright red in Autumn. 
Magnolia.

ACUMINATA-A noble, beantiful tree with very latge leaves and fragrant flowers, tinted with bluish purple.

('ONSPICLA-A beantiful Chinese variety, with large, white flowers, that appear' brefore the leares. 'Tree of small size.

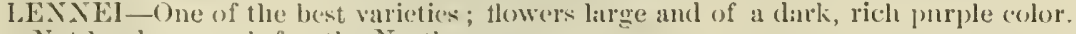
Not latrdy enougli for the North.

SPliCIOSA (Slowy tlowered)-Similar habit to the Sonlangeana ; flowers paler and bloomes later.

SOCLASGEA Y I-Rusembles the foregoing, except that the flowers are tinted with purple, and blooms rather later. A most lesirible tree for all planters.

Maple (. leer).

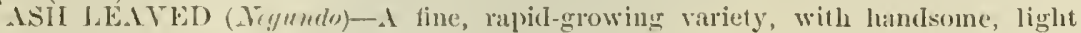
green perncented foliage and spreading houl; very hardy ; excellent for avenuer.

HER's CL'I LEAVEI) (Lecininta) - A silver Maple will remarkable and beantiful dissected foliage. Of rapiel growth; shoots slender and drooping, giving it a very graceful appearance. Should be in crery collection.

S'YCAMORE (Pendo Jlantenus) - A Iarge, moble variety, with spacious head and deep green foliage; a foce grower, and very desirable as a slade tree.

NORWA Y (Pntunerdes) - A distinct foreign variety, with large broad leaves of a deep rich greesn. P'robably the best Maple in cultivintion.

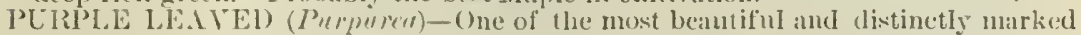
of all; leaves purple red, particularly on the under side. A rapid, strong grower; hardy, and should be in every collection.

SCAIRLET (l'nbrum) - I rapil growing tree, with red flowers vary carly in Sprug.

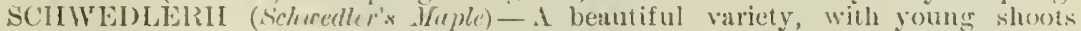
and leaves of a bright purplish and crinson color, which changes to purplish stext in the older leaves. It is a great improvenent on the well known Colchieum liubrum, the foliage being much brighter and the growth more vigorous.

SILVER I.EAYliJ) (l) immediate eflecet.

SLGAR or ROC'K (Aaceharinum)-A very popular Inerican tree, and for its stately form and tine foliage, justly lanked among the very best, both for the lawn and the arenue.

Mountain Ash (l'ylus).

ELROPLAN (Aucupuriu)-I fine hardy tree; heal dense and regulan, covered from July till wintor with large elusters of brierht scarlet berries.

(). IK LE.AVED (Quercifolin) - I variety with larges loary lobed leaves ; distinct and jine.

Oak (unercus).

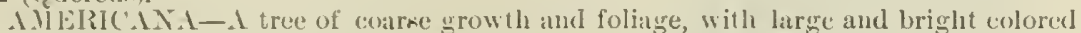
lecries.

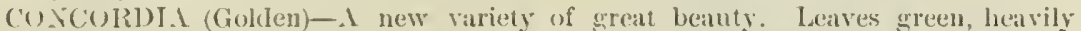
shaded with a rich golden yellow. I most striking and beautiful tree on the lawd, and slisuld be in every collection.

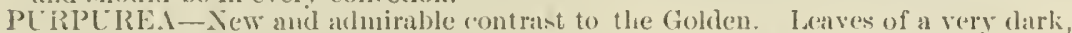
rich pmple. presenting a very striking and beatiful appearance. Very valuable.

V.IRIEG.IT.1-Leaves distincly margined with white; effective and pleasing.

Paulonia (Imperialis).

A marniticent tropical looking tree from Japan, of extremely rapiel arrowth, and surpassing all others in the size of its leaves, which are twelve to fourteen inches in diameter. Blossoms trumpet slatped, formed in large, mpright panicles, and appenr in May. Qnite hardy here, but the flower buds are killed during severe llinters.

Peach (Amygdalus)

DOCIBLE WIITTE (Abue Peue)-Very ornanental; flowers pure white and double : harly.

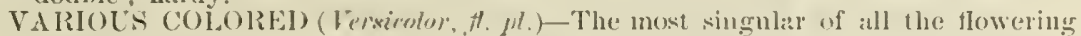
trees; flowers valiously white and red and varieguted on the tree at the same time: Flowers anrly, jerfectly hatrdy.

PLRPLRFA (Blool-İaved)-Leaves are of a deep erinson purple in the sipring.

Poplar.

FASTIGLAT.1 (Lomband)- I very distinct, well-known varety, of rapoid grow and tall, narrow form.

Salisburia (Maiden Ilair Tree or Gingko).

Al)I. XTIFOLIA - A singular and benutiful trece, foliage yellowish green, ('urionsly lobed and marked with delicately hair-like lines. 


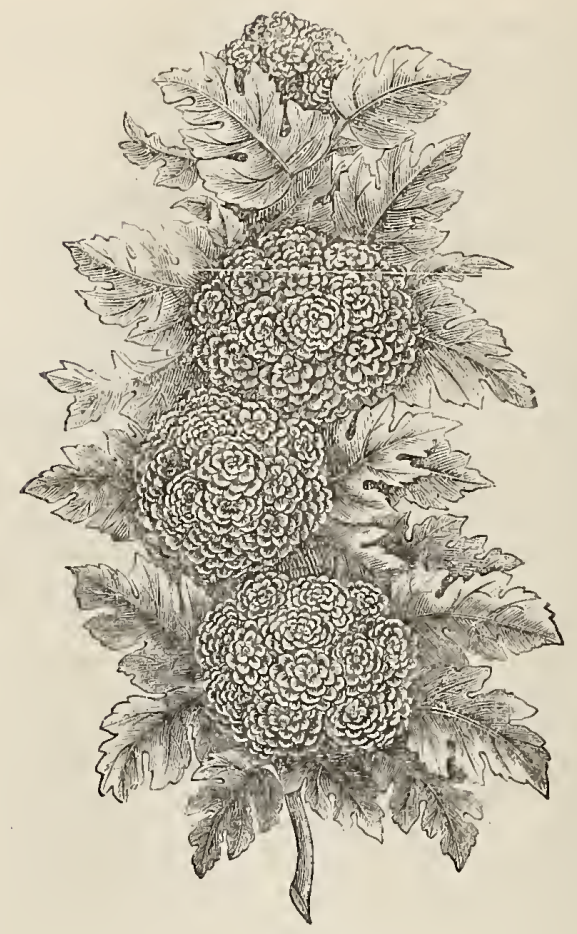

TIIORN.

Thorn (Cratægus).

1)OUBLE WIITEE (Oxyacantha Plena)-Has small, donble white flowers.

1)OUBLE SCARLET (Coccinen $f$. $p l$.) - A fine variety, flowers deep crimson, with searlet shade; very double, and considerably larger than the double red ; fine rich foliaure.

"PAUL'S NEW DOUBLE."-This is a new sort and the best. Flowers are in clusters like Verbenas; are very double, large and full, and of a deep, rich crimson.

Tulip Tree.

LIRIODENDRON TULIPIFERA-Anativetree of the Magnolia order; remarkable for its symmetry, its rich, glossy foliage, regularly distributed branches and large tulip-like flowers.

White Fringe (Chionanthus Virginica).

YIRGINICA-Blooms abundantly, bearing curious snow white fringe-like flowers, is one of the most graceful and pleasing ornaments for the lawn.

Waluut (Juglans).

NIGRA (Black Walnut)-A native species: of great size and majestic liabit. Bark very dark and deeply furrowed. Foliage beautiful, each leaf heing composed of from thirteen to seventeen leatlets. Nut round.

Willow (Salix).

ROSLMARY LEAVED (hosmarinifolia)-Very distinct and ormamental, with long, glossy, silver foliage. Makes a striking and pretty small tree when worked standard high.

Yellow Wood (Virgilea Istea).

One of the finest American trees, resulubling the Robinias, with long rucemes of white, swert-scented flowers in June. 


\section{UUleeping Deciduous Trees.}

Cornus.

NEW WEEPING (Cornus Florith perdula)-Is a variety of Cormes Floridu, which is itself known as one of the most heantiful of ormamental plants. it is adnired especially for its lorge white florml bracts, which are surceeded by real berries ats brilliant as the IIolly, while in the Fall the derpe ret folluge is one of the chref olements in our brilliant dutumm scenery.

Ash (Fraxinus).

EUROPEAN WEEPING (Entrelsior Prululu)-The common, well-known sort : one of the finest lawir and arloor trees, cowering a great space and growing ralpiclly.

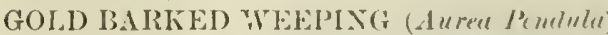
- A simgular variety, bark in 1 inter ats yellow as golel.

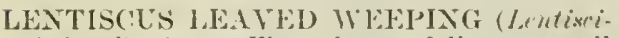
folia P'endula)-Fine glossy foliage; small leaves; clark colored bark, with silender, drooping lranches. Makes an elegant tree.

Beech.

WEEPING (Pendula). Originated in B(lgium Remarkably vigorous; picturesque tree, of large si\%e. Its mode of growth is extremely curiouts. The trmuk or stem is generally straight, with the branclies tortuous anil spreading. Quite ungainly in appearance divested of their leaves-iunt when covered witls rich, luxuriant foliage of wonderful grace and beanty.

Birch (Betulis).

CUT.LFATEL) WEEPISG (Laxciniata Pendish-In elegant enect tree, with slender, dropling brancles and fine-cut loaves. I magnigent variety, and wortlyy of a place on every lawn.

ELEC.INS PENDCLA-A new sort from Europe: luabit mearly as perdulous as that of the Kilmatrock Willow.

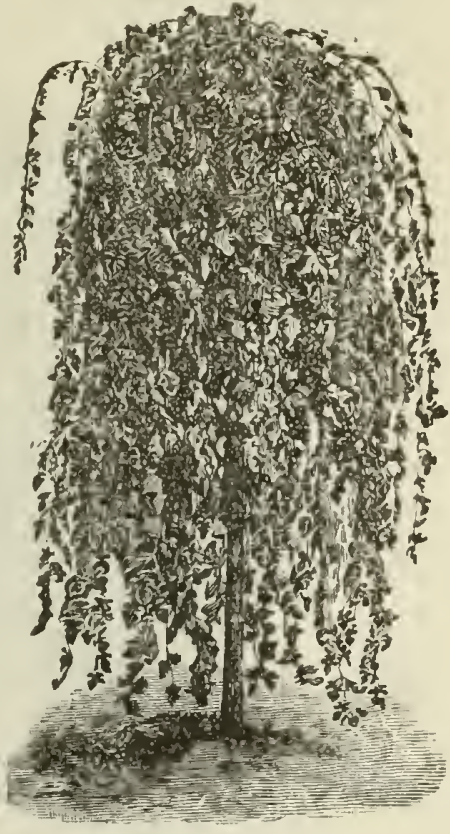

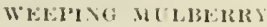

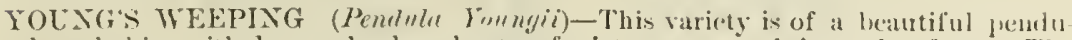
lons habit, with long, slender shoots of picturespue and irregular form. The leaves are loroul, almost lreart-slrajed, and very pretty. As a small weeping ornamental tree it has no eqnal. It is a decided accpuisition.

\section{Cherry (Cemsus).}

PEXI)LLA (Weeping)-Is worked stantard liggh, and forms a full, globular head, with shining leaves and white flowers.

PLMII.A (Dwarf Weeping)-Very delicate drooping bramehes and tiny leaves and thowers.

EIm (Člnus).

PENI)LIAA (Camperdown)-Its vigorons, irregular branches which have a uniform weeping habit, over-lap so regularly that a complact, roof-like head is formerl ; the finest W'eeping Elln.

Linden, or Lime Tree (Tilin).

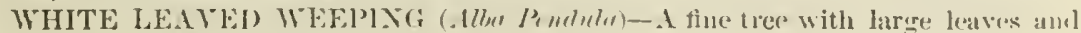
drooping branclies. 
Mountain Ash (Pyrus).

WEEPING (Aucuparia Pendula)-A heautiful tree, with straggling, weej)ing branehes; makes a fine tree for the lawn, suitable for covering arbors.

Mulberry, Teas Weeping-1 very thrifty, vigorous grower, pelfectly laardy, forming : natural umbrella-shaped top, or head, foliage handsome. New and raluable.

Poplar (Populus).

' IARGE LEAVED WEEPING (Grandidentata)-A variety having, when grafted standard ligh, long, slender branches like cords, whieh droop very gracefully ; foliage large, dark shining green and deeply serrated.

Sophora (reponiert).

PENDULA (Weeping)-Foliage and flowers similar to the upright variety ; branches angular and drooping; one of the finest weepers.

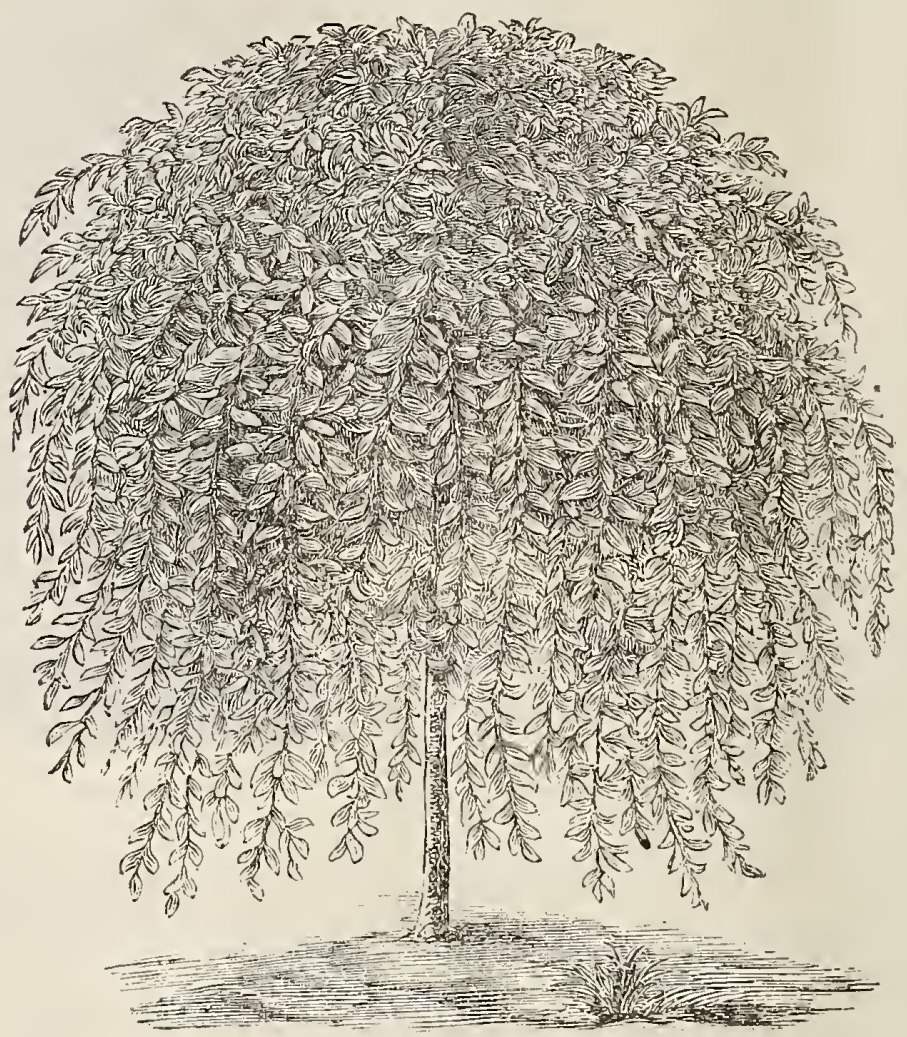

IIMARXOCK WEEPING.

Willow (Salix).

KILMARNOCK WEEPING (Camer l'mdula) - In exceelingly graceful tree, with large, glossy leaves; one of the finest of this class of trees; very lardy.

WEEPING (Babylonica)-Our common and well-known Weeping Willow.

AMERICAN WEEPING (American Pendula)-An Ancrienn dwarf, slender branehed species, grafted, five or six feet high; it makes one of the most ornamental of small weeping trees; more ornamental than the Bahyloniea. 


\section{EVERGREENS.}

Arbor Vitz (Thuja).

AMVIRICAN (Occidentalis)-This plant is, all things (onsidered, the finest Fvergreen. Valuable for hedges. It is very lawely, and casily transplanted, few or no plants ever failing if nursery specinens are obtained. It grows rapidly, and with little care, or rather by easy mamagement, it soon lorms a most beautiful ledge, very dense, and perfectly impervious to the sight. Of course it is not adapted to turn stock, but it forms a most desirable and ormumental seren 10 divide the lawn from other parts of the gromal, or for any other purpose.

COMIPACTA (Parson's)-Foliage light green; hubit dwarish and quite compart.

liRICOIDES (IIenth Icaved) - Of low, dwarfish labit, forming a round, (onnpart head, with delicate sharp pointed foliage,

PYRAMIDALIS-The most beantiful of all the Arbor Vitar, having dark gren, compact foliage and remarkably crect form i perfectly hardy.

SIBERIAN (Siberica)-The best of the grenus of this country ; exceelingly harly, kreping eolor well in Winter"; growtl compact ancl pyramidal; makes an "legant lawn tree; of great value for olnamental trees and hedges.

TOM THUMIB-Similar to the 11 cath Leaved, but mote desirable; remarkable for slow, eompact habit; valuable for planting in ecmeteries and small place's, where large trees are not adinissable.

Fir (l'icea $A$ bies, ctc).

liALSAM, or AJERICAN SILVER (Balsamea)- I very regular, symmetrical tree, assuming the conieal form even when young; leaves dark green above, silvery beneath.

NOBILIS-A lofty majestic tree, with dark shining green leaves and horizontal branches regularly arranged; one of the tinest Evergrcens native to Imeriea.

NORDMINXILN.L - This is a symmetricul and iuposing tree; the warm green of the young sloots contrasts fincly with the rieh, de'p color of the old folinge : the best of the silver Firs.

PUNGENS-Colorado Blue Spruce. Kinown for a time under the following name's : Abies Benziesii, Purryana and Ibies Engelmernii. One of the hardiest and mosi beatiful of all the Spruees; in form and habit similar to the White sipruer: foliage of a rich blue or sage color ; an iuportant acepuisition.

Juniper (Juniperus).

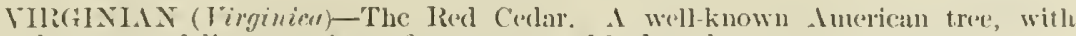
dece green foliage; makes a fine ornamental hedge plant.

IRlSII (IIbernier) - Very erect and tilpering in its growtl, forming a column of (lecp green foliage; a pretty little tree or shrub, and lor its beauty and harclinc:se is a gencral favorite.

S.IVIN (sebina) - I low, spreading tree, with handsome, dark grend foliage; very larrly, and suitable for lawns and ermeteries; can be prumed to any desired shape, and inade very oruamental.

SWEDESI (Snecicre-Similar to the Irish, thougle not so erect, with bluish-grren foilage, of somewhat lighter color than the preceding, forning a benutiful pyramidal small tree.

\section{Pine (Pinus).}

ALSTRIAN, or BLACK (Austriac $\alpha$ - A renatkably robust, hardy, spreucling tree; leaves long, stiff and dark green; growth rapicl; valuable for this country.

('liMBRA (Swiss Stone)-Of eonical form, rery uniform and dense in growth, leave: a dull green; bears purple cones; a most desirable dwart pine.

SCOTCII (syleestris) - I fine, robust, rapidly-growing tree, with stout, creet shoot: and silvery green folialge.

WIIITE (Strubns)-The most ornamental of all our native l'iness foliage light, delicate or silvery green; flourishes in the poorest soils. 


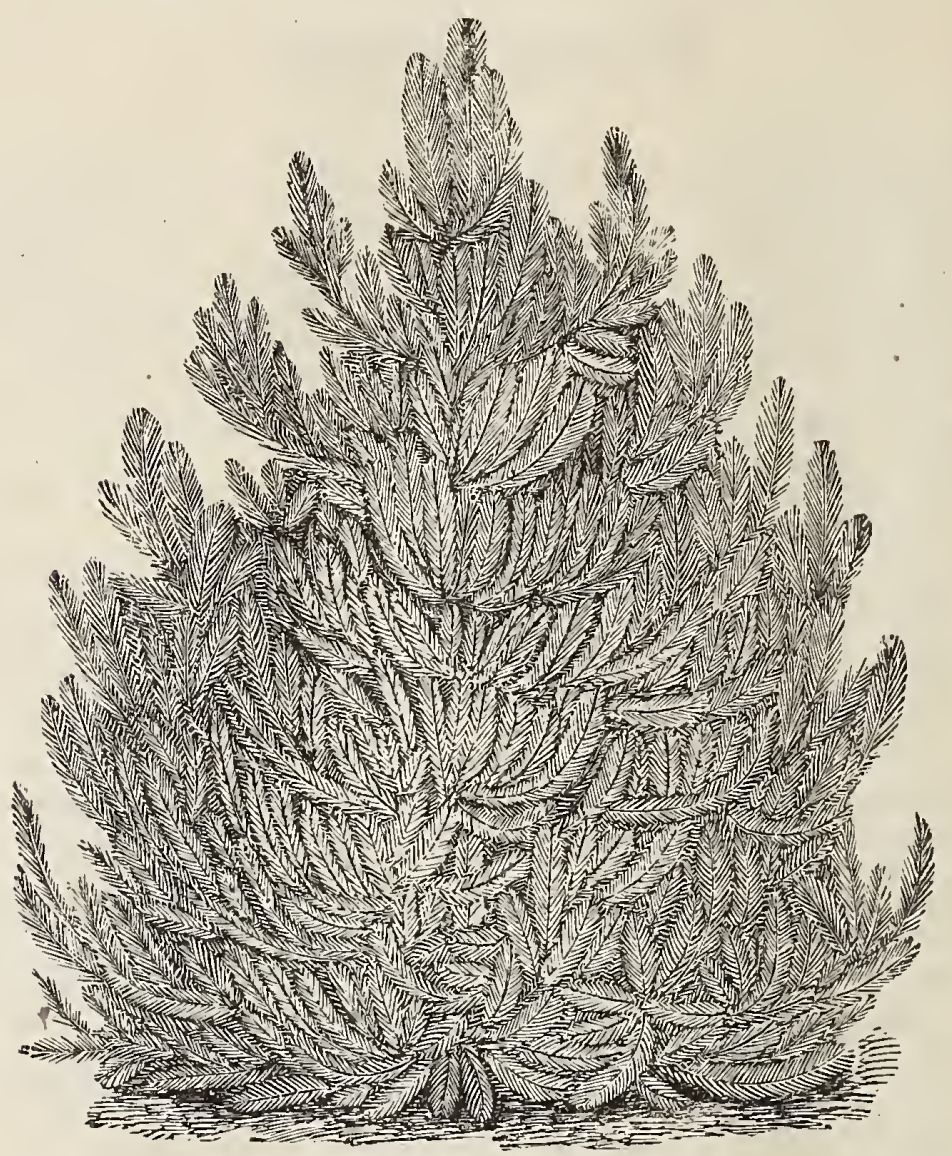

AUSTRIAN PINE.

Retinispora (Japanese Cypress).

A genus very similar to Cupressus. It comprises many sorts of wonderful beauty. They are natives of Japan, and very few will endure the rigor of our Winters without protection. Wherever they can be preserved they will anply repay the efforts made. The small varieties are exeedingly desirable for in-door eulture in pots.

OBTLSA-A tall growing variety, with spreading, graceful foliage of bright green, glaucous beneatli. A most beautiful and stately tree.

NANA (Dwarf) -A very dwarf variety of the above. Curious and pretty.

AUREA (Golden Dwarf)-The beauty of its foliage is lieiglitened by the brilliant yellow with which it is colored and which deepens with age.

PISIFER A-A small tree with numerous delicate branches and feathery foliage; one of the finest of this genus.

PLUMIOSA-A variety with fine short branehes and small leaves. The soft, plumlike appearance of the foliage gives it its name.

ARGENTEA (Silvery)-Foliage similar to the above, distinctly marked with silvery white spots; exeeedingly attractive.

Spruce (Abies).

NORWAY (Excelsute) - I lofty, elegant tree, of perfect pyramidal habit, remarkably elegant and rich, and as it gets age, has fine, gracefui pendulous branches; it is exceedingly picturesque and beautiful Very popular, and deservedly so, and should be largely planted. One of the best Evergreens for liedges. 
Spruce (Abies.)

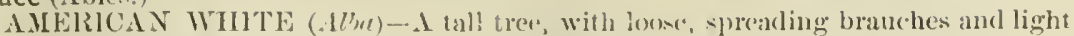
green foliage.

PENI)UL.I (Weeping)-l hetves dark glossy urreen : branches very drooping.

P'GALEA-A dWarf variety of the Norway; grows from thee to fonr feet high, very compact.

IIEMLEOCK or WEEPING (Cnunelenviss)-An elegant pramidal tree with drooping branehes and delicate, dark foliage, bike that of the Yew ; distinct from all other trees. It is a bentutiful lawn tree and makes a highly ornamental hedge.

Yew (Taxis),

EREC'T ENGLISII (Buceata Ereste)-A very tine pyramidal variety of the English Yew, with dark green folinge; hardy and desirable.

ELEGINTISSIMI - A beantiful tree of small, dense habrit; leaves striped with silver, frequently turniug to light yellow:

WASHINGTONII-New, vigorous in growth, and rich in healthy green and golden yellow foliage; one of the best.

\section{Deciduous SHRubs.}

Althea, or Rose of Sharon (Hibisens).

These are fine shrubs, and especially valuable beealse of their Howering in the Fall when all other shrubs are out of bloom. Entirely hardy and easy of enltivation.

130ULE DE FEU-A fine new variety, of vigorous growth, Flowers large, very double, and of a beatutiful violet recl eolor.

I.IR, COERLLEA PLENA-Double blue Althea.

DOUBLE VARIEGATED, or P.IINTED LADY (Vuriegut!s flore piena) - Hine double flowering, variegated pink and white.

DOUBLE LILAC (Ponniftort) - Very handsome, double lilac-tlowering.

DOUBLE PURPLE (P'וrpurea)-Donble, redelish purple.

DOUBLE RED (Rubre Plemo)-Donble red flowers.

V.ARIEGA IED LEAVED DOUBLE PURPLE (Vuriggtis Ftore Pleno) - A very showy kind; distinct, leaves variegated with light yellow; Howers double purple; exeeptionally tine.

Almond (Amygdalus). (Knoen correctly as Prunus Joponicu, Fl. Rub. pleno, ete.)

I) WARF, DOUBLE ROSE FLOWERING (Pumiln Rosit) - A betntifnl shrub. with small, double-rosy blossoms.

I)

Amorpha (Bastard Indigo).

These are fine large shrubs, with small pmrple or white flowers in clense terminal panicles in July.

FlatTICOSA (Ährubby Amorpha, or Wild Indigo). Native of ("urolinat and Florida. Flowers dirk bluish murple in June and luly.

Anemone, Japonica (Albil).

A very tesirable, thoroughly linrdy, pure white lawn or garden plant. Grows about 1s inches high. Flowers about two inches in dimmeter. Blooms in the Fall. Very beantiful for cemetery plots.

Berberry (Berberis).

COILION EUROI'EAN (Vulguris)-lRed frnited.

PLRPLE-LEA VED (Purpnrea)-An interesting and beatiful variety, with violetpmrple leaves and fruit.

Buckthorn (Rhamnns).

PLIRGING (C'utherticus) - A valuable, hardy, romst shrub, with elark, rich folingreand white flow'rs, followed by blaek berries. C'sed extensively for hedges, and being very hardy, is one of the most desirable plants for this purpose'.

Calycanthus, Sweet Scented Shrub, or Allspice.

FLORII) 's (Sweet-seented Shrub)-In interesting shrub, having a rare: and peculiar fragrance of wood and tlowers; its blooms are abundant and of a peetuliat ehocolate color.

\section{Clethra.}

ALNIFOLIA (Aler-Leaved)-A native slirub of low and dense growth; laves abundant and light green; has numcrous spjikes of sinall, white. fragrant Howers. Blooms abundantly in July. 


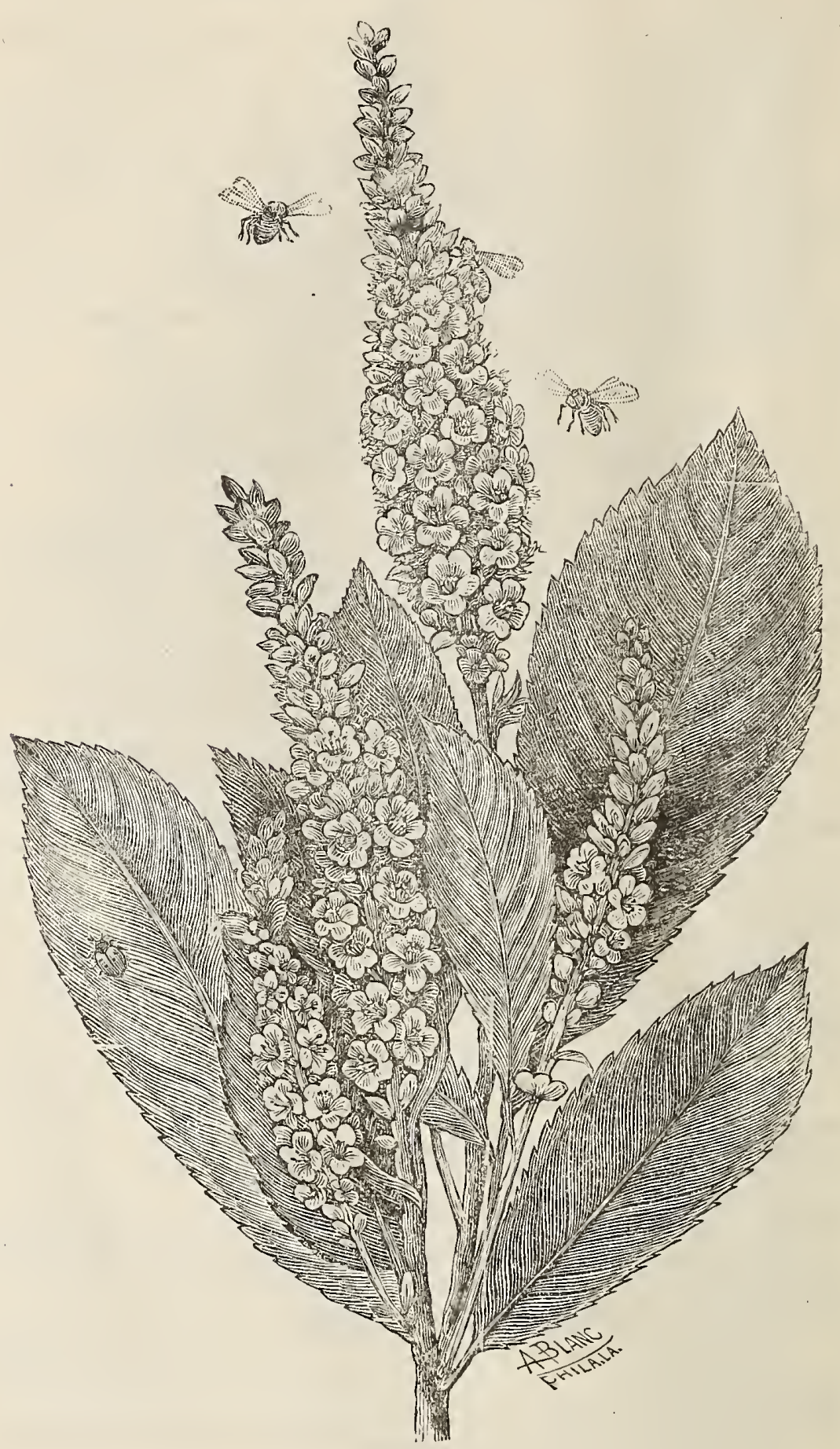

CLETHRA. 


\section{Currant (Ribes).}

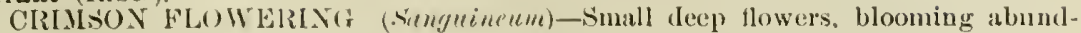
antly and carly in sipring.

YELLOW FLOWERING (.1 1 mem)-Bright shining leaves and yellow flowers.

\section{Daphne.}

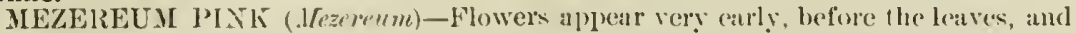
are very bchintiful.

TR.MLING (Cnomum)- I very low evergreen shrub, blomming al intervals from May to November. Flowers rose colol.

\section{Deutzia.}

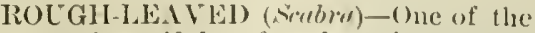
most beantiful profuse flowering shrubs: white.

SLENUER BIRANCHE']) (crurilis)-I elnaming species, introlucerl from Japau by Dr. Siebold; flowers pu:c white; fine for pot culture, as it tlowers ers freely at a low temperatne in winter.

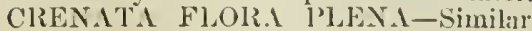
in growth and liabit as the abore: flowers double; white tinged with rose.

C.INI)IDISSIII (1)ouble white Howering)-One of the finest slimbs, producing snow-white tlowers of great beauty, and valuable for bouguets and baskets.

Dogwood (Colnus).

MASCLLA VARIEG ITA-Leaves striped with pale yellow or white; very beatifnl.

COIR N ELI A N CHLRRT (1/usrulu)liright yellow flowers in May.

RED BR.LNClIEl) (s'mgnimu)-Very eonspieuous and ormanental in 11 inter on account of its blood-red bark.

Exochordia (Grandiflora).

A vigorous growing, finely shaped shut, with light foliage and wood, and a great profusion of flowers in May; ; very desirabie.

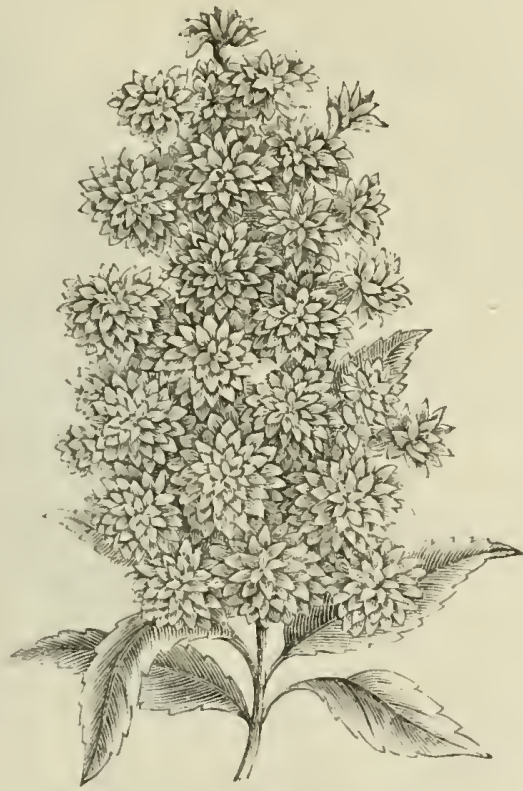

1) $1:$ T $\% * 1.1$

\section{Euonymus-Burning Bush-Strawberry Tree.}

I very ormamental aukl showy shmb), whose chicf beauty consists in its brilliant berries, whieh hane in chusters from the branehes until midwinter ; berries rese

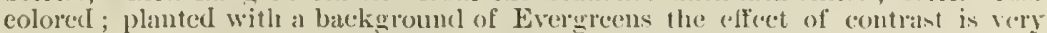
fine.

IUUROP.ECS (Eumpenn Enomymus)-Forms a tres sometimas :) fort in hoight. Fruit rose-colored.

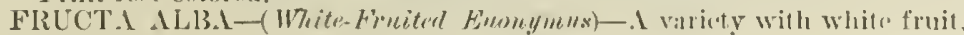

\section{Elder-(Simbucus)}

IULE.1-I handsome variety witl golden yellow folinge and clusters of pure white flowers's very desirable for omumenting lawns.

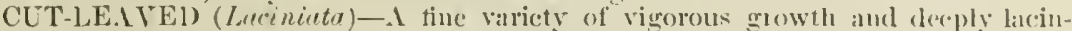
iated foliage.

VARIEG.ITED-LEAIVED (Vuriegutı)-Al hatrdy, variogaldel shmb) rery showy and fine.

Filbert-f(Corylus.)

PLRPLis-LEAVEL (I'urpureu)-I very conspicnous shrub, with lat're, dark, purple lenves; distinct and fine.

\section{Forsythia.}

V1RIDISSIJIA-Lanves dark erreen : tlowers bright vellow; very ently in spring. I tine had shrub). Introdiced by Mr. Fortume from China

Flobe Flower (Kírilia)

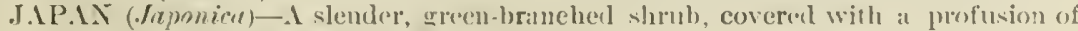
elobular vellow tlowers from . Inly to (x)tober. 


\section{Halesia, or Silver Bell.}

FOUR-WINGED (Tetraptera)--1 fine, large and very ornamental shrub, with beauful white, bell-shaped flowers, in great abundanee in IIay.

Honeysuckle, Upright (Lonieera)

RED TARTARIAN (Tartarica Rubra)- 1 well-known shrub ; flowers bright pink, which appear in May.

WHITE TARTARIAN (Tartarica Alba)-Like the preeding, but laas dull, white flowers.

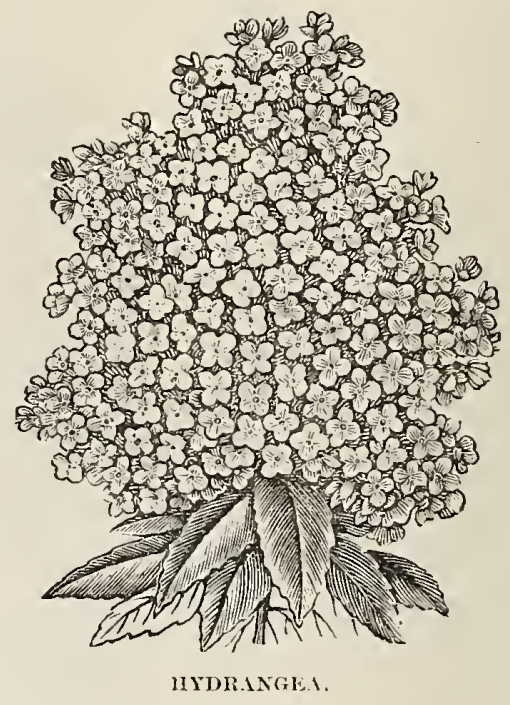

Hydrangea.

LARGE CLUSTERED (Paniculata)--A fine large shrub, bearing showy panicles of pink and white flowers in the greatest profusion. It is quite hardy, and is altogether a most admirable shrub for planting singly or on a lawn in masses.

QUERCIFOLIA (Oak-leaved Iydrangea)-A hardy, massive sinub, of wooly growth and bushy habit. Leaves lo bed like those of the oak, and downy hineath, turning to erimson in Autumn. Flowers white, ehanging to purple.

OTAKSA--Large foliage of a deep green ; bears a profusion of decp, rose-colored flowers in luge tresses; new and very fine.

THOS. IIOGG-A beautiful variety with large tresses of pure white flowers. Not hardy, but very valuable for forcing.

\section{Lilac (Syringa.)}

CILARLES THE TENTH-A strong, rapid grower, with large shining leaves, and reddish purple flowers.

CHIONANTIIUS LEAVED (Josikca)--Has dark, shining lcaves like the White Fringe Tree, and purple flowers, fine and distinet.

COMLION PURPLE (Fulgaris Purpurea.)

DOUBLE LILAC (Lemoinei Flore Pleno)-A new and choiee variety of the Lilar, producing long racemes of double purple flowers, lasting longer than the singli. sorts. A valuable aequisition.

PERSIAN (Persica)-Medium sized shrub, with small leaves and bright purple thowers.

WIITE PERSIAN (Persica Alba)-A tine sort; white flowers, delicately tinged with rose eolor.

LARGE FLOWERING WIITTE (Alba Grandiflora)--I beautiful variety; has very large, pure white panieles of flowers. Considered the best. 


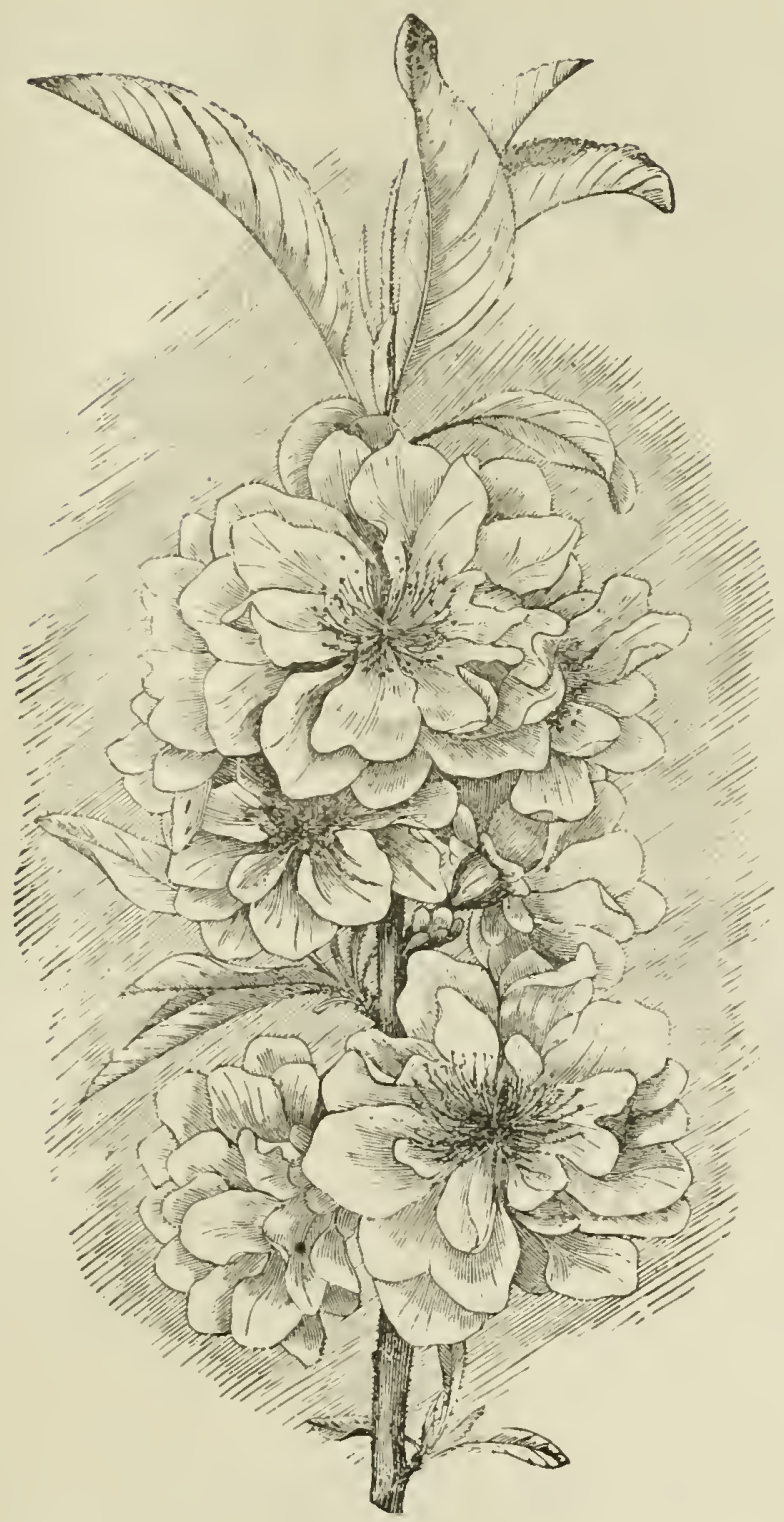

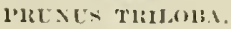

Plum (Prunus.) (See double-flucereng Almonel.)

PIRLNLS PISSARDII-The wood and leaf ane of a rich, peculiarly vivid dark purple, holding the color well through the entire season, and in this respect superior to Purple-Ieaved Birch, or any purple-leaved tree we have. It also producea black fruit of oruamental appearanee, early in the season.

'TRILOBA (Donble Flowering Plum)-A highly interesting and desirable addition to hardy shrubs: flowers semi-double, of a delicate pink, upwards of an inch in dianeter, thickly set on the long slender branelies: native of China; hardy. 
Purple Fringe, Smoke Tree (Rhus Cotinus).

A very mueh admired and eonspieuous shrub or small tree, with spreading habit, so as to require eonsiderable spaee; covered in mid-summer with a profusion of dusky, fringe-like flowers, desirable for its striking peeuliarity of flowering.

Quince, Japan (Cydonia Japoniea).

SCARLET-An old and esteemed variety, having a profusion of bright scarlet flowers in early Spring, and one of the best eariy shrubs we have; makes a beautiful and useful hedge.

BLUSH JAPAN $(A l b a)-\Lambda$ beautiful variety of the preceding; witl a delieate white and blush flowers.

\section{Snowberry (Raeemosus).}

Has tiny pink flowers sueceeded by white berries that hang for months.

\section{Spiræa.}

The Spiræas are all elegant, low slirubs, of the easiest eulture, and their blooming extends over a period of three months.

BILLARDI-Rose eolor. Blooms nearly all Summer.

CALLOSA $A L B A-\Lambda$ white flowering variety, of dwarf habit; very tine.

DOUBLE FLOWERING PLUM LEAVED (Prunifolia $f l$. $p l$.)-Very beautiful; its flowers are like white daisies; from Japan. Blooms in Mlay.

DOUGLASI (Douglas' Spirea)-Has spikes of beautiful deep rose eolored flowers in July and August.

EXIMEA-Flowers bright rose eolor. July. One of the best.

ELM LEAVED (Ulmifolia)-Leaves somewhat resembling the Elm. Large, round clusters of white flowers.

GOLDEN LEAVED (Aurea) - An interesting variety, with golden-yellow tinted foliage, and double white flowers in June. Very eonspieuous.

LANCE LEA VED (Lanceolata)-Narrow pointed leaves, and large, round elusters of white flowers that eover the whole plant; a charming shrub. Blooms in May.

REEVESII Fl. Pl. (Reeves' Double)-Flowers white and double; blooms freely in clusters. One of the best.

V.IN HOUTTI-One of the most eharming and beautiful of the Spirxas, having pure white flowers in elusters or panieles about an ineh in diameter. Astonishingly profuse in bloom, and plants remarkably vigorous and hardy. But lately introdueed from France, and there is no more desirable flowering shrub in cultivation.

Syringa (Philadelphus),

All the speeies and varieties of the Syringa have white flowers, many of them quite fragrant.

GOLDEN LEAVED (Aurec $($ ) -A very pretty plant of medium size with golden yellow foliage. It retains its eolor the entire season, and is valuable for ereating pleasing and striking eontrasts with botl green and purple-leaved shrubs.

LARGE FLOWERED (Grandiflorus) - A eonspienous showy kind, with large flowers and irregular branehes.

\section{Tamarix.}

AFRICAN (Africana)-This is a very beautiful shrub, with small leaves, somewhat like the Juniper, and delieate small flowers in spikes.

\section{Viburnum.}

SNOW BALL (Opuluts) -A well-known favorite shrub, of large size, with globular clusters of white flowers in June.

PLICATUM (Plicate Titurnum) - A rare and exeeedingly beautiful speeies from Japan. Flowers pure white, in very large globular heads.

White Fringe (Chionanthus).

VIRGINIAN (Virginiea)-One of the best large slurubs or small trees, with superb foliage, and delieate, fringe-like white tlowers. 


\section{Weigela.}

AMABILIS OR SPLENDENS-Of much more rolust habit ; large foliage and flowers, and blooms freply in Antunn ; a great acquisition.

DESBOISII-A beatifnl variety, with decp rose-colored flowers, resembling kosea, but flowers much darker. One of the darkest and best.

FLORIBUND.1-Flower's of a rich crimson, and has the additional merit of usually making at second growth and flowering profusely during the latter part of Sunmer. It is from Japan, and perfertly hardy, and aldapted to our clinute. Boing of such a dark, rich color, it is at great acquisition as compared with tho pale pink flowers of Rosea and other sorts.

HORTENSIS NIr'E._-Flowers pure white, retaining their purity the whole time of flowering. Foliage large, labbit vigorons. A very prof use bloomer.

ROSE COLORED) (Rorea)-Au (degant shrub with fine rose-colored flowers. Introduced from Chint by Mr. Fortume, and considered one of the finest plants he has discovered. Quite hatrdy; blossoms in Mlay.

VAN HIOUTTI-A ncw variety of vigorons growth with dark rich crimson thowers, produced in great abundance. Darker than Desboisi, and al decided acciusition.

VARIEGATED LEAVED (Fol. Vuriegata)-Leaves bordered with ycllowish white, finely marked ; flower's bright pink

\section{Climbing Shrubs.}

Akebia.

QUINAT $1-\Lambda$ fine rapid growing climber, with dark'green' leaves, ind purple blossoms in early Summcr.

Ampelopsis.

VEI'TCHII-A miniature foliaged ereeper, which clings witl the tenacity of Ivy ; beantiful leaves of a glossy green shaded with purple; perfectly hardy, and colors finely in Autumn.

Aristolochia (Birthwort).

SIPHO (Tube flowered, or Dutchman's Pipe)-A twining vine of rapid growtl, law ing large, dark green leaves and curious browish pipe-shitped bloom.

Bignonia, or Trumpet Flower.

SC.ARLET (Rudirnns)-A splendid climber, vigorous and hardy, with chusters of large trumpet shaped scarlet flowers in .I ugust.

LARGE FLOWEIRED (Grandiflor $(t)-A$ magnificent vine with large towers; very showy.

Honeysuckle (Loniceri).

MONTILX FRIGR.ANT or DUTCH (Belgicu)-Bloons all summer; very swcet.

COMIION WOODBIXE (Periclymennm)-A strong rapid grower; flowers very slowy ; red outside, buff within. Jnne and July.

CHINESE TWIXING (.Japonion)-Holds its folinge nearly all Winter; blooms in July and September; and is very sweet.

IILLLE.LXI (Hall's New)-Nearly crergreen ; Howers pure white; produced abundantly; ; fagrant like a Jasmine.

YELLOW TRLMPET (Faru)-A well-known variety, with yellow trumpet-like Howers.

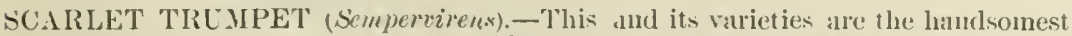
in cultivation. It is a strong, rupid grower, and produces searlet, inodorons flowers all summer. 


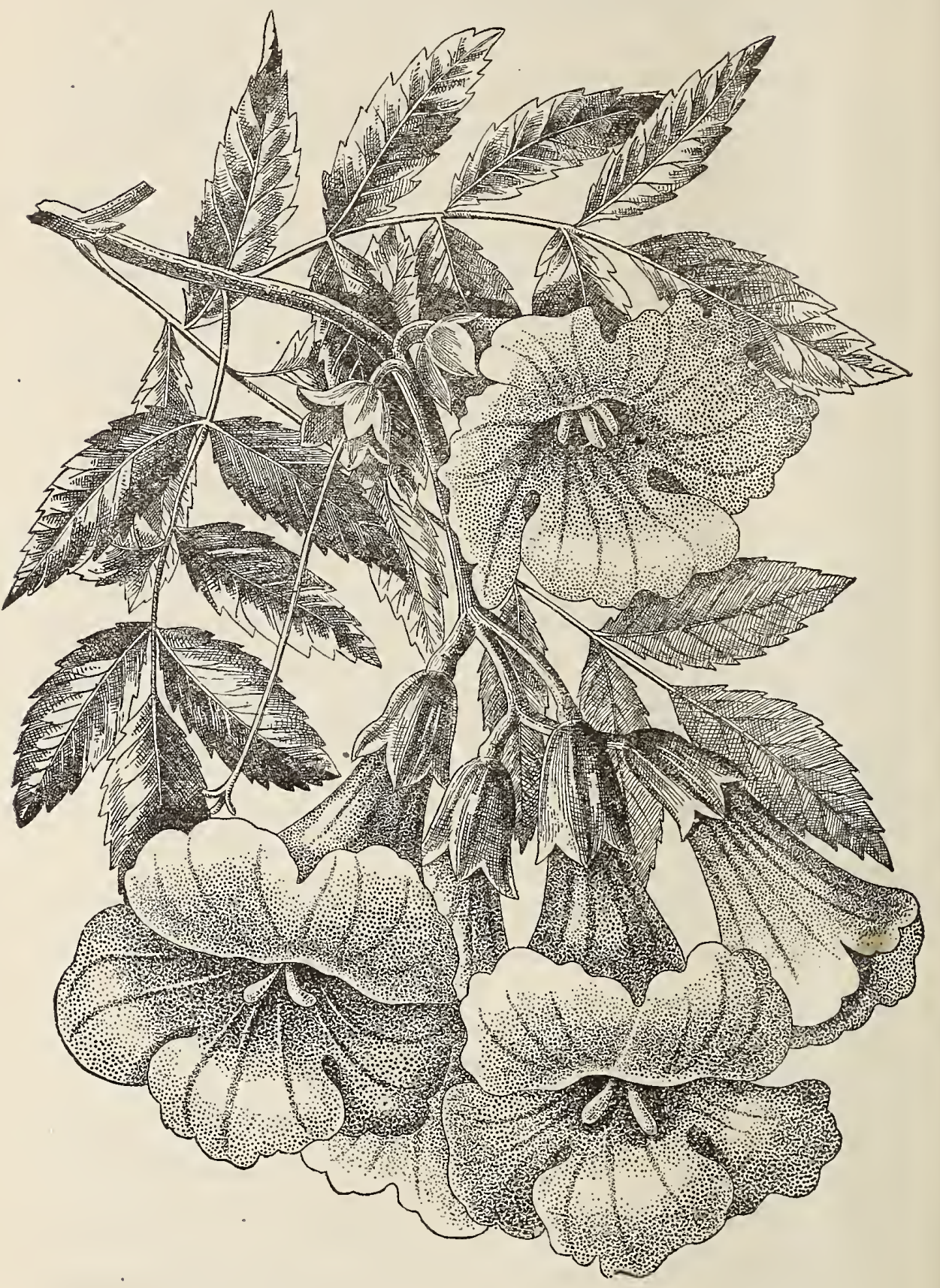


Ivy (Hedera).

ENGLISII-A well-known, old and popular sort.

NEW SILVER STRIPED - Deep green leaves, heavily margined with white; very striking.

VARIEG.ATED LEAVE1) (Fol. Vurieguted)-With smallor leaves than the preceding. The Evergreen lvies often suffer in Winter if exposed to the sun, and should therefore be planted on the north side of a wall or huilding.

Virginia Creeper (Ampelopsis Quinupuefolia).

A native vine of rapil growth, with large luxuriant foliage, which in the Autumn assumes the most gorgrous and magnifieent coloring. The blossoms, which are inconspieuous, are sueceeded by landsome dark blue berries. The vine is best calenlated to take the place in this eountry of the celebrited English Iry, and is really in Slınmer not inferior to it.

\section{Wistaria.}

CHINESE (Sinensis) $-\Lambda$ most beautiful climber of rapid growth, and producing long pendulous elusters of pale blue flowers. When well establislied, makes an enormous growth; it is very liardy, and one of the most superb vines ever produeed.

DOUBLE PURPLE (Flore Pleno)- $d$ rare and charming variety, with perfectly double flowers, deeper in color than the single, and with raeemes of remarkable lengtl. The plaut is perfectly lardy, resembling the Wistaria Sinensis, so well knowin as one of our best climbing plants.

AMERICAN (Frutescense)-A native variety of vigorous habit, and small elusters of light blue fragrant flowers.

CHINESE WHITE-Introdnced by Mr. Fortume, from ('hina, and regarded as one of lis greatest aequisitions.

AMERIC.LN WIITE-I native seedling, pure white. Bunches short. I free bloomer.

MAGNIFICA-Flowers in dense; drooping meenes, and of a pale lilac coior. Vigorous and perfectly harly.

\section{CLEMATIS.}

Hardy Climbing Plants with unost gorgeous flowers of nearly every shade, from deep purple to pure white; miny of the flowers are from fonr to seven and eiglit inches in diameter, growing very rapidly and flowering profusely. All the varieties delight in rich deep soil and a sunny exposure, and need supports to which they should be fastened as they advance. They are well adapted to covering unsightly objocts, and are used to advantage about roekwork. Are now the most popular ornamental flowering plants. Are benefitted by liaving the roots mulched during winter with any coarse inaterial, such as manure, etc.

THE FOLLOWIXG FLOWE ON SHOOTS OF THE I'LLEEXT SE.LON'S (AROWTH.

Alexandria-This is one of the eontinnons blooming sorts of real morit; has a vigorons habit of growth and in flower is remarkably showy and ormamental. The flowers are large and of a pale reddish violét color. New ind desirable. July to Oetober.

Flammula - In old and well-known variety, which is highly prized for the fragrance of its small, white flowers and its remarkably dark green leaves, which remain on the plant very" late. A rigorons grower. Jnily to (ontuber.

Grand Duchess-A splendid variety, with flowers about nine inches across, bluish white, and of good (1nility. First-elass certificate lioyal IIortieultural soeiety.

Gipsey Queen-Ricl, bright dark velvety purple ; very free, late flowering.

Gem-1 new and raluable perpetual blooming variety. The flowers are of a deep lavender blue. The parent plant, though much weakened by propagation, had upwards of one hundred flower huds as late as the middle of Octoler, 1871. Jime: to Uctober. 
Gloire de St. Julien-This is one of the bent new perpetual white varieties. The flowers are very large and abundant. Jume to October.

Hendersoni-This is a handsome variety of very free-blooming character. The flowers are of a rich, bluish purple color and bell shaped. It is ornamental, not only on account of the profusion of its flowers, but also for the long continuance of its blossoning season. June to October.

Henryi-New, and one of the best perpetual hybrids, of robust liabit and a very free bloomer. The flowers are white, large and very showy. July to October.

Jackmanni-This is perhaps the best known of the newer fine perpetual Clematis, and should have credit of the great popularity now attending this family of beautiful climbers. The plant is free in its form of growth, and an abundant and successional bloomer, producing flowers until frozen up. The flowers are large, of an inteuse violet purple, remarkable for its velvety riclmess. Though raised in 1862since which time many new varieties have been raised and introduced-the Jackmanni has no superior, and very few, if any, equals. July to October.

Jackmanni Alba - strong, vigorous grower, perfectly hardy, and a most prolific bloomer. The flowers are pure white, and make a tine contrast when planted witl Jackmamni.

Jeanne d'Arc -1 free growing. vigorous variety. The flowers are very large-seven inches across- of a grayish or French wlite color, with three bluish veins in each sepal ; delicate and beautiful. July to October.

Louis Van houtte-A strikingly slıowy variety, with bluish purple flowers. First-class certificate Royal Horticultural Socicty.

Lord Neville-Flowers large aud well formed ; color, lich dark plum, stamens light, with dark anthers; edges of sepals finely crimped. First-class certificate Royal Horticultural Society.

Lady Caroline Nevil-Beautiful bright mauve, with deeper lars. Very fine.

Lady Boville-This very fine variety has peculiar and well-formed cupped flowers, of a clear, soft, grayish blue. It is il vigorous grower and free and continuous bloomer. July to October.

Lanuginosa Candida-A variety of the above, having large, delicately tinted, grayish white flowers, which become white after the flowers are fully expanded. One of the best. July to October.

Lanuginosa Nivea - This is one of the finest of blooning plants: it las great merit in these particulars, viz, : it is pure white-it is a perpetual bloomer-it opens its first blossoms earlier than Jackmanni, and thence continuing to bloom onward until arrested by frost. June to October.

Lawsoniana-A hybrid variety, showy and free, with very large, beautiful rosy-purple flowers, which are produced profusely and in continuous succession. July to Oct.

Madame Van Houtte-I new white vilucty, having thowers remarkably fine in size and quility. July to October.

Magnifica- $\Lambda$ very distinct and effective Clcmatis. $\Lambda$ free flowering variety of the Jackmanni type, giving a good profusion of blooms continuously. The flowers are of a rich purple, with a distinct red bar through the center of cach flower leaf. July to October.

Marie Lefebvre-A new, vigorous growing variety, with large flowers of a pale silvery mauve, with a deeper mauve colored bar. July to October.

Modesta-This variety has a free-growing and free-blooming character, with flowers of a tine form, and of a bright blue color. July to October.

Mrs. James Bateman-Tlis is a new variety of great merit; a free successional bloomer, continuing thronghout the season to yield an abundint crop of its showy blossoms, which arc of a reddish lilac, changing to a pale lavendar as they become older. July to Oetober.

Otto Frœbel.-This is a splendid variety, with a very robust habit and very large flowers, of a grayish tinted or French white color, and a good form and texture. July to Octoher.

Princess of Wales - $\Lambda$ deep bluish mave, with a satiny surface. An exceedingly fine Clematis. 
Purpurea Elegans-Deep violet purple, light-eolored filaments, and pinkish brown anthers. First-elass certiticate lioyal llortieultural society.

Perfecta--This is a very the variety of the Lanuginosa class, with large, white, wellformed and handsome tlowers; slightly tinted at first, but blenehing to pure white. Jily to Octobir.

Prince of Wales-This is one of the very profuse flowering varieties, of vigorous habit, showy and free. The flowers are of decp purple with a red har in the center of ench tlower leaf. First-rite for bedding as well as training up. July to Oetober.

Ramona-This new Clematis originated at Nowark, $N$. Y. It is a strong, ranpant grower, very much stronger than Jackmanni, of ten growing teu to twe've feet the first season. It is a true perpetual blooner, flowers appearing on the last year's growtl and on the new shoots, giving an abundance of bloom all through the season.

In size the flower surpasses any ft the old sorts, often six to seven inche's in dianeter, and of the most perfeet slatpe. Color, deep rich lavender. Distinct from any other sort ancl very attractive. Perfectly hardy and remarkably vigorous.

Robert Hanbury - I bluish lilae, flushed at the edge with red and having the bar slightitly fringed with red.

Rubella-One of the finest of the Jackmanni class, having the same habit of abundant and eontinuous bloming until frozen up. The flowers are large, and of a deep velvety claret color; showy and effective. July to Oetober.

Rubro Violacea-This is another of the Jackmanni class, producing flowers in great profusion, which are of a maroon purple, flusherl with recldish violet. One of the best. July to Oetolser.

Samuel Moulson-Mauve, with a redelish tint on the bars.

Star of India- I very showy, very frec thowering sort, with lange flowers, first of a reddish plum color, chimging to a violet purple, wilh turkey-red bar in the center of each flower leaf. I distinet variety of great merit. July to Oetober.

Tunbridgensis-1 very fine variety, laving flowers of remarkably good form and reddish-lilae eolor, with a centrat band of bluisl matuve. This viriety can be used to advantage with the Jackmanni and other datk colored sorts. July to Oetober.

Velutina Purpurea-This variety has great merit in being the darkest colored Clematis of the class. It lats the vigorous, free-blooming character of the Jaekmanni. The Hower's are large and of a very rieh blackish mulberry-purple eolor. New and choice. July to October.

Viticella Major-This is an improved form of the Viticella; is a free grower, with flowers of re(ldish-plun color.

Viticella Rubra Grandifora-Tlis is the nearest approach to a crimson Clematis yet obtained. The flowers, whieh are very abmndant, are of a dull crimson color; and lias green stamens. July to Oetober.

Viticella Venosa-A beautiful Clematis of free growth. The flowers are above medium size; the eolor is a pleasing tint of reddish purple, elegantly veined with erimson. July to October.

The folloring rurietics flower in Spring and eurly summer, from the old or ripened roud of the previous yeur's groesth.

Albert Victor-This is one of the early flowering hylrids, having large flowers of a deep laventer, with a pale bar in the center of each sepal. The flowers are produced freely from the last of May to the first of July.

Aureliana-A valuable hybrid variety; flowers large and of a lively porcelain blne eolor, which are prodiced in great profusion. Jnne to Oetober.

Coccinea (Sc:arlet Clematis)-Flowers most brilliant searlet, quite nulike that of ans other Clematis. Bloons in July. Very choice and desirable.

Duke of Norfolk- A very deep mauve color, with a broatlish pale bar. The anthers are dark colorecl.

Duchess of Teck--I pure white, with a faint, delicate manve bar. A rarcled firstclass eertifieate by the lioyal Botanie Society. 


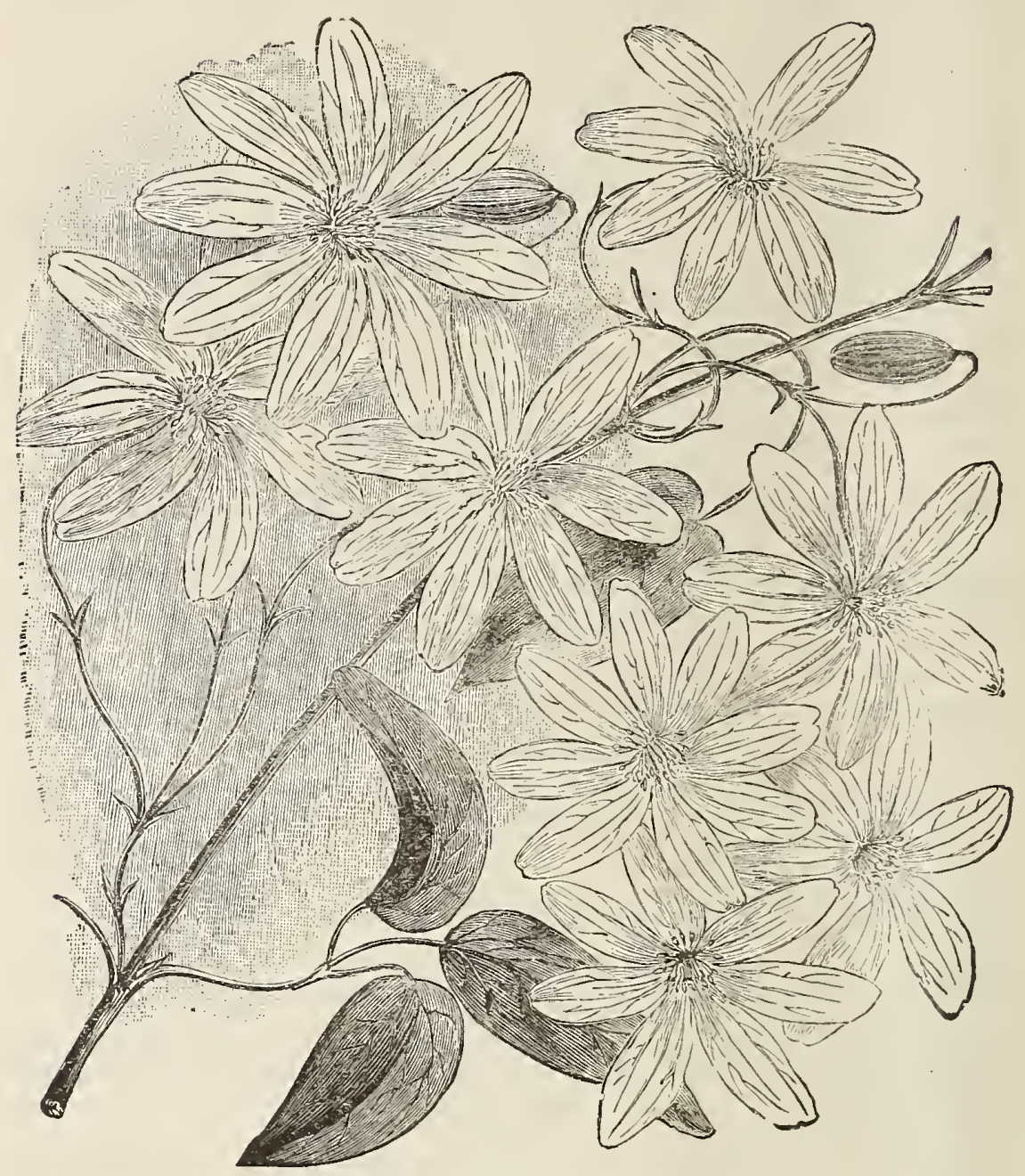

CLEMATIS INDIVISLA.

Fair Rosamond-Free growing and handsome. The flower is fully six inehes aeross, and eonsists of eight sepals. The eolor is white with a bluish east, having a light wine red bar up the eenter of eaeh sepal. Flowers very fragrant, and are abundant through June and first of July.

Indivisia-Has pure white, sweet flowers produeed regularly along the stem, well adapted for floral deeorative work, and is fine for bouquets.

Lady Londesborough-One of the best of the early flowering Japanese Hybrids. The thowers are large, of a silvery gray, with a paler bar in the eenter of eaeh sepal. June to July. 
Lord Derby-Anthers redelish purpie, with white filanents.

Lady Alice Neville-Color rosy lilac, with pale mauve bars. Certifieatc Rojal Iforticultural society.

Mrs. Geo. Jackman-Satting white, witl a creamy bar. This variety often llowrr. on the young wood, giving it more the charaeter" of a perpetual blooner. "This is one of the best of the ently flowering whites.

Miss Bateman--(O) of the most chaming of the Spring llowering hybrick, laving large white fowers, with chocolate red althes, and somewhat fragrant. May and Junc.

Montana-A renarkibly free-rowing, excerdinmly olmanental, latrly, Indian-clinber, well adapted for trailing over walls or trellises. The flowers are white, with a dash of pink and tuft of straw colorerl stamens. Sweet serited and very copious-the branches literally becoming eomverted into tloral garlands.

Standishi--Introdueed from Japan. A remarkably free-growing varicty, with beauciful richly-colorerl, very tinely former tlowers, of at light matre purpto color. One of the best. Junce.

Stella-New. Tery showy, one of the choicest. The flowrors are of a lighter violet or

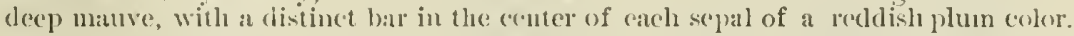

The Queen-1 uew varicty. having a fres habit and remarkably handsomo foliage an: flowers of a delieate lavinclir color.

Virginiana- I very strong grower, having fraglant white llowers. Valuable for covering sereens.

\section{DOUBLE SORTS.}

Duchess of Edinburgh-This is without doubt the best of the pure whites. Delieions!y scented.

Enchantress - I very large and distinet variety. Good habits, bearing very double white flowers. The exterior petals are very prettily flushed in the eenter with rose. First-class certificatc loyal llorticultural Society.

Excelsior-I listinct, double-flowered sort, with flowers about six inches across, of a grayish purple or (cep) mauve color, marked with a jlum-eolored bar; the outer flower leaves of the same color as the lartge ones. It is a tirst-chiss eertificate variety.

Fortune-This was introduced from Japan by Mr. Fortume. The flowers are large, louble, white and somewhat fragrant.

John Gould Veitch-Sont from Japan in 1862. The flowers are very handsome, distinet, larce. double, and of a light blue or lavendar color. It is like Fortunci, exeept in the color of the thowers. June and July.

Lucie Lemoine-Vew. Flow'rs white, doubie, linge and well formed; composed of i.) to 90 pet:ils, very showy. June. 


\section{Cameluia.}

The Camellia is not sufficiently hardy for open air eulture and requires artifieial warmth and proteetion. It blooms through the Winter and early Spring months, and reguires a soil of rich loam and well rotted compost, thoroughly mixed.

Alba Plena-White ; one of the best known and best varieties in eultivation.

Carswelliana-Variegated. Fine.

Chandlerii---Red and white.

Elata--Dark crimson.

Duchess d'Orleans-Flesh colored, striped with white.
Jeffersonii-Bright crimson. Fine form. Lady Hume's Blush-Flesh eolor.

Sherwood--Rosy crimson.

William IV.-Splendid; variegated red and white.

William Penn-Cherry red. Fine.

Wilderii-Bright rose. Fine form.

\section{Hardy Ghent Azhlehs.}

This elass of Azaleas are suffieiently hardy for open air eulture and will stand our winters without proteetion, though a mulehing of straw or loose litter is desirable, at least until they beeome established. They are among the most beautiful of flowering shrubs, presenting the best effeet where massed in beds. They require no other than an ordinary garden soil, with moderate fertilizing eaeh year.

\section{LIST OF VARIETIES WITH BIIEF DESCRIPTIONS.}

Amcena--Bright purple and louble.

Calandulacea Flammea-Searlet.

Coccinea-Dark orange.

Cordon--Light orange.

Bouquet de Flore-Pink and white; fine.

Cruenta-Scarlet; fine.

Dr. Gray-Scarlet.
Ne Plus Ultra--Orange; fine.

Penicellata Stellata--Straw color and salmon.

Wm. C. Bryant-Pink anil orange.

Narcissa Flora-Splendid yellow, double. Nudi Flora-Pink and white.

\section{CHINESE AZALEAS.}

These are less desirable, half hardy and require the proteetion of conservatory, greenhouse or frames during Winter. Otherwise they may be treated the same as the Ghents.

Alba Perfecta-Fine White.

Amarantina Splendida-Rosy purple.

Adolphe de Nassau--Large rose.

Coloris Nova-Superb crimson.

Georgiana-Copper red searlet.

Louise Margottin-White, semi-double, striped with erimson.

Iveryana-White, striped with rose.
Marie Van Houtte-Large, semi-double; white, striped and blotched with rosy salmon. Lxtra fine.

Madam Perrine--Variegated.

Marie Vervaine--Variegated, crimpel. Fine.

Symmetry-Good form; rosy silnuon.

Triomphe de Ledeburg--Scarlet r'rimson. Fine. 


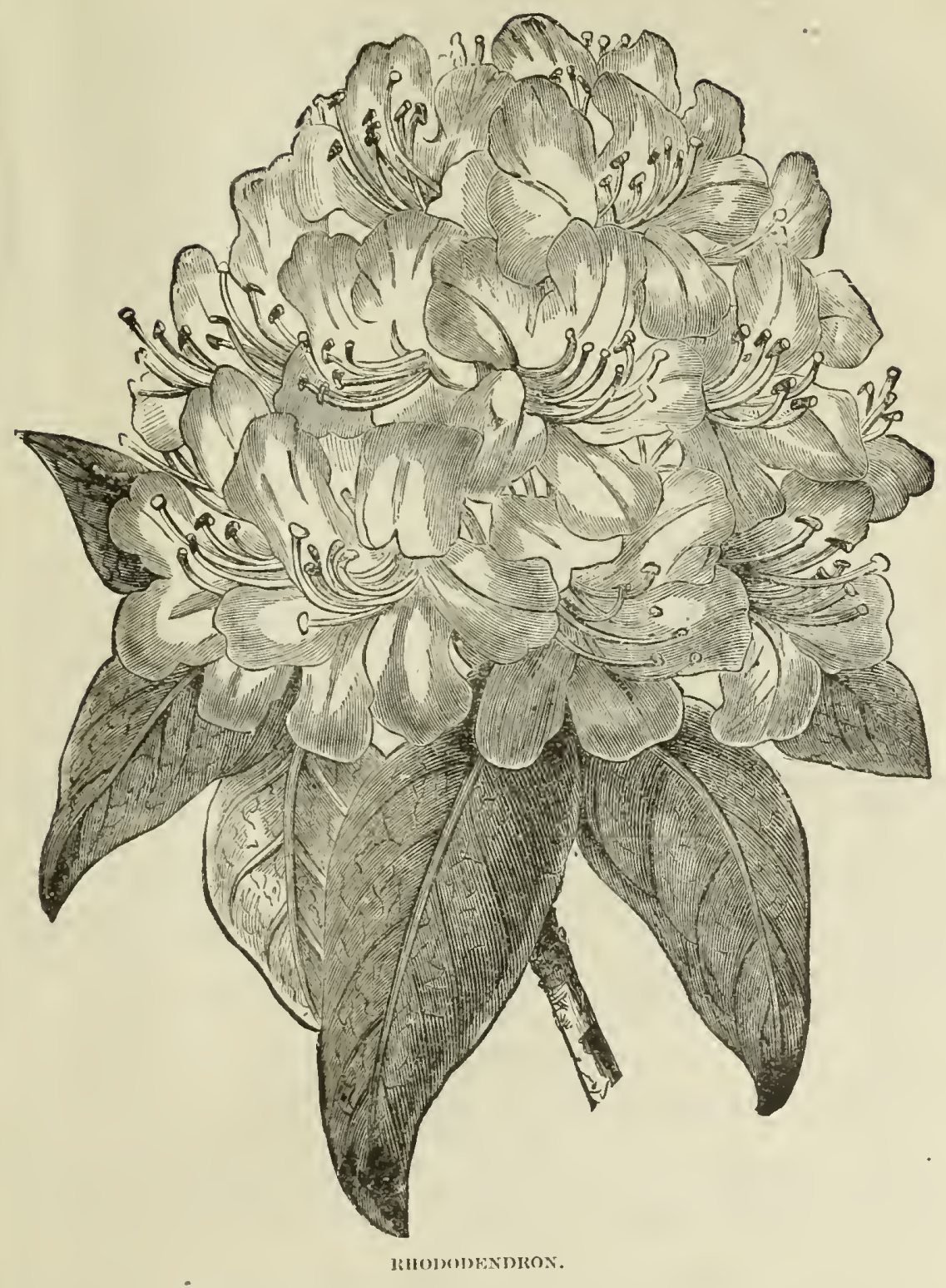

RHODODENDRONS.

These are the most magnificent of all Evergreen Shruls, with rich green foiliage sbr? superb clusters of showy flowers. They flourish best in a rich garlen soil, numl hike Lzaleas, are most effective when grouned. 
The following varieties ane atirely hardy and alapted to a Northern elimatr:

Album Elegans-Large white flower ; an admirable variety and strong grower.

Abraham Lincoln--A superb crimson; very tine foliage.

Bertie Parsons--Lilae blusl.

Bicolor-Dark rose.

Blandyanum-A very bright rose, One of the best.

Grandiflorum-- Deep rose, inclining to crimson; an abundant bloomer. One of the best sorts.
Catawbiense (Seedling)--Having lilac colored ind red flowers simply.

Everestianum-liosy lilac, with crimped petals and yellow eye. Very fine.

Perspicuum-iVlite.

Purpureum-Purple.

Roseum Elegans-liosy tinted. Very fine.

Roseum Superbum-il good lite sort: rose colored.

Speciosum-i light pink; late hloomer.

\section{Roses.}

\section{HYBRID PERPETUAL OR HYBRID REMONTANT.}

Hybrid or Remontant Roses are perfectly lardy, free and constant bloomers, of all shitdes of colors from very dark to perfectly white.

To obtain the most satisfactory results, they should be planted in rich, deep, well drainerd soil, and severely pruned in early Spring, before the buds start.

Achille Gonod-Dark carmine red; very large, full and bold flower.

Alfred Colomb-Bright carmine red; clear eolor, large, deeply built form; "xceedingly fine.

Anna de Diesbach-Carmine; a beautiful shade, moderately full and very large.

Augusta Mie-Clear, rosy pink; very large and finely cupped; vigorous, fine.

Baron de Bonstetten-Rich, velvety maroon; large, full. A splendid sort though a slyy bloomer iu Autumm.

Barronne de Maynard-Pure white, medium-si\%ed flowers; gool form ; very double ind one of the most persistent of blooners.

Beauty of Waltham-Almost full ; beautiful, bright elerry color.

Baronne Prevost-Deep rose; very large and full; a vigorous grower and abmulant bloomer ; one of the oldest and tinest of this class.

Belle of Normandy-Silver rose color; large, full, and globular in form. Extra fine.

Baroness Rothschild-Light pink, cupped form, very symmetrieal, without fragrance, very beautiful; a molerate grower only.

Climbing Jules Margottin-Carminc rose, lightened witl pink; full flowers of mellium size, very pretty in bud. This is a decided acquisition ; the flowers are the same as in the old variety, except that they are a little smaller, and quite as freely produced; the growth is more vigorous.

Countess de Serenye-A seedling from La Reine, but shows much of the Jules Mrargottin character: Silvery pink, often mottled ; full, finely shaped, globular flowers, of medium size; wood light green, foliagn darker, thorns red ; slightly fragrant; very distinct ; not always reliable about opening, but a very f ree bloomer, and well wortlyy a place in a smaill collection; deeidedly one of the tinest Autummal roses, and also one of the most beautiful for forcing. 
Countess of Oxford-I scedling from Victor Verdier; Iright carmint fanding in the sun ; very large aud full ; not fragrant. Woorl almost thornless ; foliage very haud some, large and distinct. Fine in bud, valuable for foreing.

Charles Lefebvre-Fine bright red, (enter purple shaded; lange and globular ; one of the grindest roses.

Caroline de Sansal-('lear, delicate tlesh mlor, becoming blush; magnificent variety ; the best rose of its color in the catalog1.. surpassing even the Vietoria, which is very similar in color; growth vigorous and foliage luxuriant.

Climbing Victor Verdier-liosy camme, pulplish edges; showy and very eflective.

Coquette des Alps-White, lightly shaded with 'anmine; of medium si\%"; a frer bloomer.

Captain Christy-Delicato flesh color, shated rose in the center ; a large, finely formed tower.

Coquette des Blanches-Pure white, flowering in clusters; a very free bloomes.

Doctor Arnal-Bright crimsun, fine form, large and double; good grower, free bloom ' 1 .

Duke of Edinburgh-lich, velvety vernillion; very hady and vignorous.

Dinsmore- I true perpetual, llowering very freely the whole seison; fowers large and rery double; eolor dece crimson. The plant is of a dwart, bushy habit, every shout producing a bud.

Empress of India- Lu inperial lose in every respeet ; splendid form, very large, full aud double; very fraglant; dark violet erimson, finely shaded and velvety.

Eliza Bœlle-White, lightly tinged with rose; modium size, good form.

Francois Michelon-Deep (ammine rose; very large, full and one of finc globular form; flagrant and a frec bloomer. A seedliug from La Reine. A very distinct, choice sort ; exeellent late in June and July, when other varieties are grone.

General Washington-Brilliant losy crimson; large and louble; fine.

General Jacqueminot-Brilliant crimson scarlet; very showy and effective.

Giant of Battles-Very deep, brilliant crimson center ; dwarf habit, free bloomer and one of the very best.

Joasine Hanet-- l'mplish red, very full; blooms in clusters.

John Hopper-liose, with rosy crimson center; splendid form.

Jules Margottin-Light, brilliant crimson ; large, full and beatiful.

Louis Var Houtte-Beautiful maroon; medium size; full, of fine shape, deliciously perfumed.

La Reine-Bright rosy pink; very latge, double and swrat ; oue of the best.

Leopold Premier-Bright dark red ; fine form, large and s. $_{-}$.

Leopold Hausburg-Bright earmine, large and full; labit sonewhat penlant.

Louise Margottin-Beantiful pink; cupped form,

Lord McCartney-Crimson, as hight as General Jac (queminot ; of very tine appearance; prolific in bloom and very hardy; very desirable.

Madame La Charme-White, sometimes faintly shaded with pink; moderately larere; a tree bloomer in sipring.

Madame Laffay-Rosy crimson, large and double; one of the best.

Mrs. Elliott-Bright rose, large, vigorous and one of the best.

Mademoiselle Eugene Verdier-1 seelling from Victor Verdier. Beautiful silver loses; large, full, of tine form ; large, lustrous foliage, exquisite buds ; of great merit.

Mabel Morrison-A sport from Baroness Rothschild. Flesh white, ehanging to pure white; in the Autumn tinged with rose; donble, eup-shaped flowers, freely producerl. In all save substance of petal and color, this variety is identical with Barone's Rothsehild. Though not so full in flower as we would like it, it is the best white IIylurid Perpetual raised. 


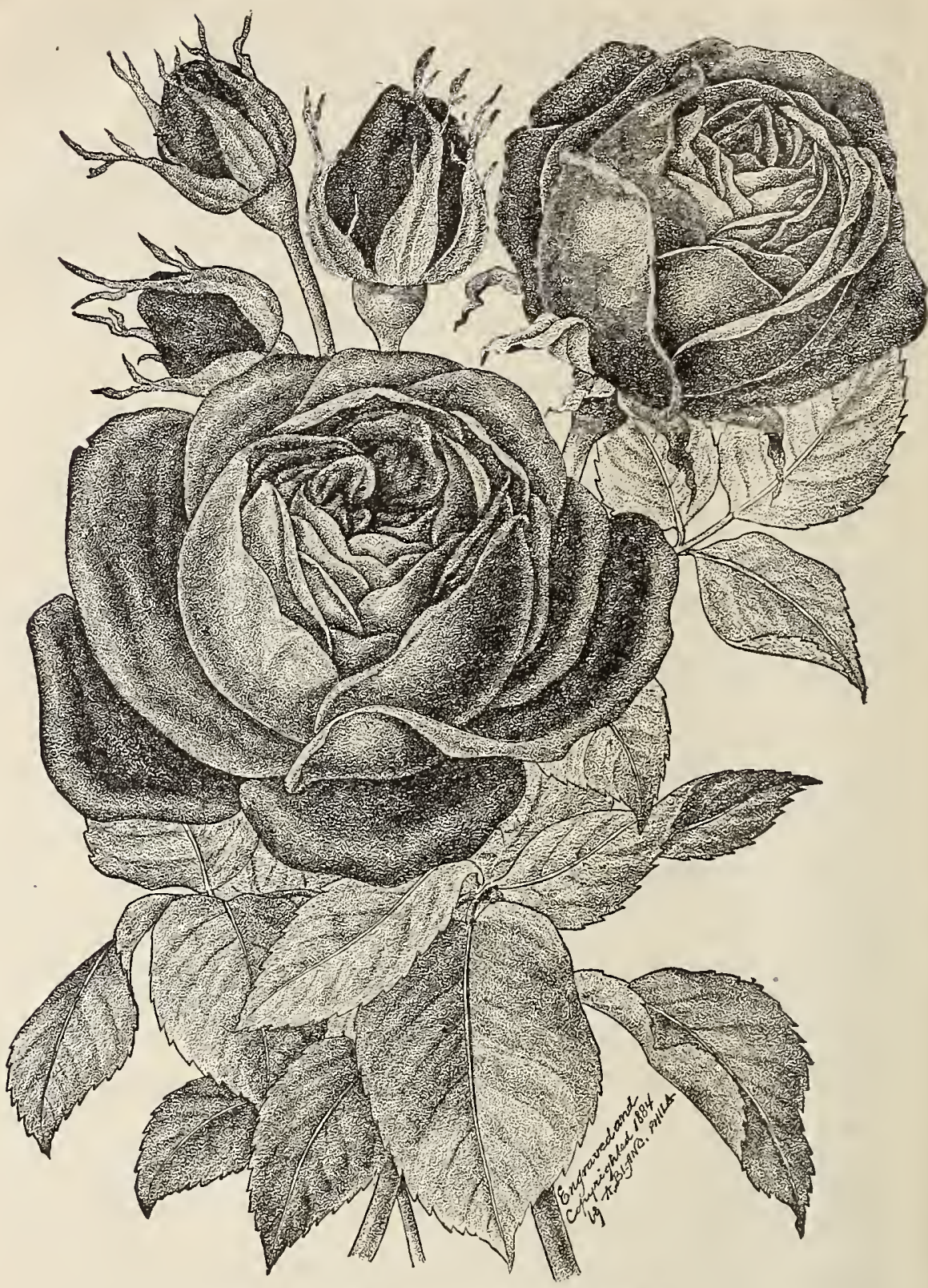

HYBRID PERPEIUAL OIR REMONTANT ROSE.

Madame Charles Wood-One of the most valuable IIybrid Perpetual roses ever introdueed. The flower is extra large, full and double ; eolor deep, rosy crimson, sometimes brilliant searlet, with maroon slading; it blooms soon after planting out and continues to bloom all summer.

Marquis of Salisbury-Deep rose, with erimson slading. Perfectly imbrieated, round, globular form, like a well arranged ball ; a grand autumnal rose, and perhaps the finest shape yet raised; a strong, compaet, hibited plant. 
Marchioness of Exeter-A seedling from Jules Margottin. Free; rosy velmilion ; size medinm or large; form semi-globular, full, fragrant. I rose of considerable substance.

Madame Victor Verdier-Bright cherry rose; large, romput and fincly ('upped ; blooms in clusters; in free bloomer.

Madame Boutin-Dirk cherry rose; large and of bold, globular form.

Marshall P. Wilder-Cherry enmine; eontinues in bloom long after otler valrieties are out of flower; the finest II. P. rose yet producel.

Paul Neyron-Deep rose color, good foliage; by far the largest variety in cultivation.

Pzonia-Clıery red, brilliant ; extra fine form ; a beautiful rose.

Pierre Notting-Deep velvety crimson. I beantiful globular-shajed flower, distinct and tine.

Pius the Ninth-Bright purplish red, changing to violet; very large and full; rebust and profuse blooner ; onc of the best.

Portland Blanche-Pure white tlowers, like Blanehe Vibert. Sial to bloom more freely in tlie Fall.

Prince Camille áe Rohan-1)eep velvety crimson; large, moderately full. I splendiu rose.

President Lincoln-Dark crimson, medium size, rich. I most prolific bloomer and should be in every collection. 11 ardy and a fair grower.

Perle des Blanches-Yigorous, very large and full, well formed; white center, changing to flesh eolor.

Richard Smith-Velvety maroon; very clark.

Reine Blanche-Pure white, bentifully cupped. Exceedingly beatiful both in bud and bloom.

Star of Waltham-Carmine Crimson, unedium or large size ; semi-globular, full. Foliage very large. Smooth green wood, witl oceasional red thorns.

Sir Garnet Wolseley-Vermilion, shaded with bright earmine. Color well maintaincl throughout.

Sydonie-Blush, large and fine, distinct; a vigorous grower.

Victor Verdier-Clear rose, globular, fine form and free blooner. Superb.

Victoria-Pale blus!l, nearly white, ver's large, full and double. Strong grower anI abundant bloomer.

William Griffith-Rosy lilac, large and beautifully formed, vigorous and profuse bloomer One of the best.

\section{HYBRID TEA ROSE.}

These are produeed by crossing Tea Roses and Hybrid Perpetuals. La France iz of this class, and is probably more lighly prized than any other Rose. They are not quite as robust as the Hybrid Perpetuals, but sufticiently so to endure our elimate witl a little protection in winter.

Beauty of Stapleford-Flowers large, double and lumlsomely formed, color briglit pink, shading gradually towards the center to deep rosy carmine. Mlakes beantiful buds and is a profuse bloomer.

Charles Margottin- A seedling from Jules Margottin, reddish crimson; form sentieupped, very large, full and sweet, retains color well and is a vory fine bloomer; foliage slightly crimperl.

Cheshunt Hybrid-Cherry carmine, with a slatele of violet ; flowers large, full, slightly fragrant. I fine bloomer in spring, but not in Iutumu ; distinct and fine.

Countess of Roseberry-Victor Verlier type. Clucry red; a gool color ; large, full, cupped; not fragrant ; smootl wood, bamlsome foliage; promising.

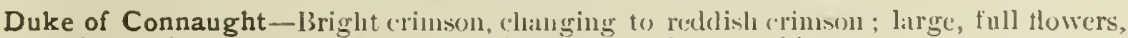
without fragrance, I showy, good liose, botll in bul arid flower. 


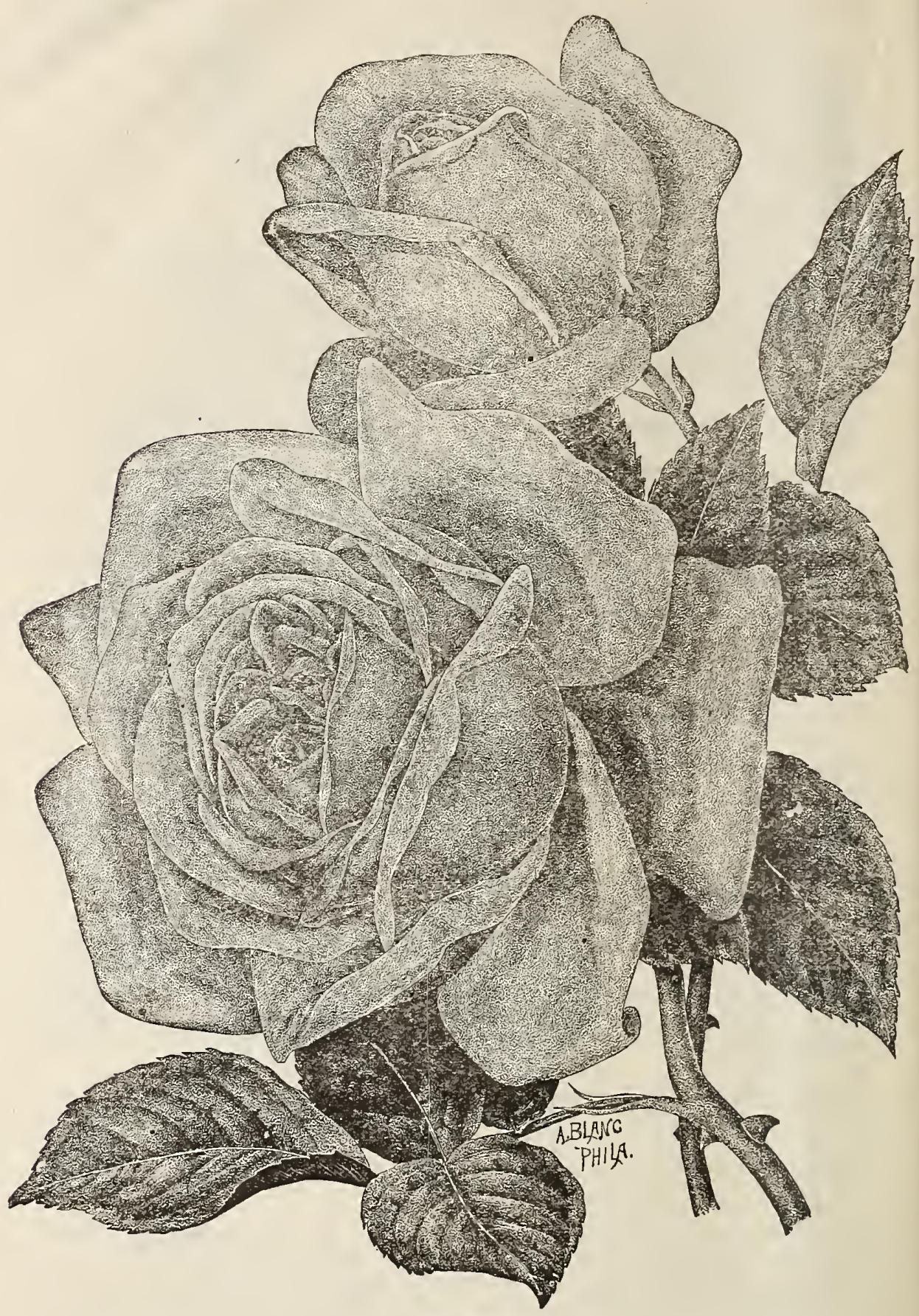

TEA ROSE. 
Duchess of Connaught--Silvery rom, of latreg ghloblat form, lighly scenterl. lioth in color and fragrance this valrety resembles lat France, but the flowers are more cirenlat and the foliago larger. If it provessulliciently distifet from Lat france it will bra great aldition.

Duchess of Westminster-('aminc-lose, large, full llowerk, with a filint 'l'al oulur. "l'his

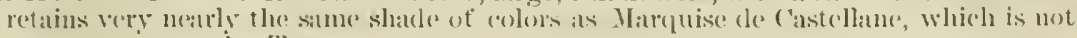
common anomg the "leas.

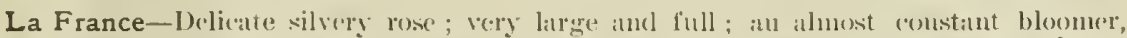

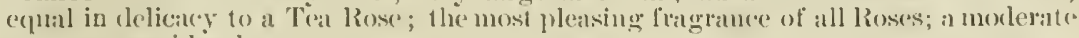
grower ; semi-liturly.

Jean Sisley-lilatrose; large or very latre; very full, without fragrance. A very free-bloomer, always in thower, but hiving too much substance it is not valuable for foreing, the bukls not opening well; more valuable for open ar enlture than for the hothse.

Michael Saunders-Free or moderate. Bron\%el rose, a distinct color ; lurge, bemutifully formel flowers, which, from their great fulluess, do not always open well muler glass, but are tine in open air ; somewhat fragrant.

Nancy Lee-Sintiny rose, of a very clelicate and lovely sluade. Beautiful buds, of medium si\%e, highlì perfumed; growth slender.

Pierre Guillot-Bright dazzling crimsou, passing to brilliunt caumine ; petals beantifully" reined with pure white; flowers very double and full; a frecbloomer and very sweet.

Puritan-I beantiful pure white varety of the most delicious fragrance. In sime and shape of tlower it very chosely resimbles the llybrid l'erpetual class, with the flowering habit of the ever-blooming section. The flower is strounded by a wreatl of foliage which sets it off to the best alvantage.

Viscountess Falmouth--(Seeded from President, fertilized with Moss Rose Soupert Notting). Flowers extra large and full, splendid form, color delieate pinkish rose, back of petals bright (armine. This eolor overlipping the other gives it a most lovely a1)pearance ; very distinct and beautiful. It is a coustant bloouer anel rery fragrant.

William Francis Bennett-This is a magniticent variety for pot culture or for forciny tlowers in Winter. It is one of the most popular Roses witl the ent flower arowrers for Winter use. The buds are of "xepuisite shitpe, long and printed, like Nipletos, and riviling Geu. Jiscquemint in its rich glowing erinson color.

\section{BOURBON ROSES.}

These are not quite so hanly as the preceling rass, requiring slight protection in the North. They are continual bloomers, of vigorous, rapid growtl, with rich luxuriant folinge.

Blanche Lafitte- Pale flesh color ; full and beautiful.

Hermosa-Light blush or flesh color, linge, full and ilouble; grows freely and bloomi profusely; fine.

Louise Odier-Fine bright rose, large, full ("up)exl form.

Louis Margottin-1)elicate satin rose, fine form ; free bloomer, and a sllper'i) new rew.

Omar Pasha-sicurlet crimson, fine and vigorous; one of the very best.

Queen of the Bourbons-Fawn colorel lose, heautiful and profuse bleomer.

Sir J. Paxton-Deep rose, shaded witl erinson; v'ly strong grower, fine lich foliage and free bloomer.

Souvenir de la Malmaison-Pale fesh, witl a fawn shade; very large, full, luautiful. 


\section{NOISETTE ROSES,}

These are the finest autumnal bloomers, and are distinguished by flowering in elusters. They are not quite hardy, requiring a little proteetion during severe winters.

Augusta-Sulphur yellow, large and full, very fragrant, strong grower similar to, if not identieal with Solfaterre.

Caroline Marinesse-Creany white, small and full, nearly hardy; flowers resemble those of Felieite Perpetual.

Cloth of Gold (Chromatella)-Rieh, deep yellow ; large, double, fragrant, and a vigorous grower.

Celine Forestier-Fine, bright yellow, highly fragrant, a strong grower and profuse bloomer; a fine rose.

Larmarque-White, with sulphur center, howers in clusters. A magnifieent elimbing rose under glass.

Lady Emily Peel-lias pure white flowers in large elusters; a free grower and fine for pillars.

Narcisse-Pale yellow ; a beautiful tea-scented rose.

Yellow-Sulphur yellow; rather feeble grower.

Solfaterre-Bright sulphur yellow, large and gobular.

Woodland Margaret-Pure white, rather small ; a free bloomer.

\section{TEA ROSES.}

The perfume of these Roses is most delieate and agreeable; indeed, they may be ealled the sweetest of all Roses. The flowers are also very large, and delieate in their colors, sueh as white, straw, and flesh eolor, and various tints of rose combined with them. They are more tender than any other rose in the eatalogue, requiring a house or pit in Winter. They are most desirable for pot eulture.

Bon Silene-Purplish earmine.

Catherine Mermet Bright flesh color, with the same peeular silvery lustre possessed by La France; large, full and beautiful form ; decidedly one of the tinest Tea Roses,

Cornelia Cook-A seedling from Devoniensis. Pale yellowish white, sometimes tinged with flesh; flowers very large and full ; not a free bloomer, and often does not open well, but a superb rose when well grown.

Jeanne d'Arc-Pure white, very fragrant and beautiful; strong, luxuriant grower; fine pillar rose.

Clara Silvain-Pure white, large and full.

Clothilde-Bright salmon rose; large, full, of good shape, hardy and effeetive.

Devoniensis-White, with blush eenter; large and fine.

Duchess of Edinburgh-A very desirable novelty. Flowers of good size, moderately full, deep crimson in the buds, beeoming brighter as they expand ; good for Winter flowering.

Empress Eugenie-Silvery rose, medium size ; full, fragrant ; a good variety.

Glorie de Dijon-Yellow, shaded with silmon and rose ; large, full and distinet.

Isabella Sprunt-Sulphur yellow, very fine; espeeially desirable for house blooming.

Marechal Neil-Very bright, rich, golden yellow ; very large, full and perfeet form ; the petals are extra large and of good substance; of vigorous growth and a free bloomer. This is unquestionably the finest of all Tea Roses.

Madame Bravy-White, with rose eenter, large and fine. 


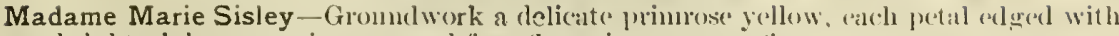
bright pink: vory vigorons and free flowering ; al very tine rose.

Madame Welche-Amber yollow, depening towirl the center to arange or appery yellow; delientely tinged and shaded with reddish crimson ; the flower is extra linge; globular form, very double, full and exceedingly sweet. An extra tine variety.

Madame Joseph Schwartz-A streng, vigorons grower and one of the liardiest tea roses for out-door bedding. The flowers ane ('up-shinped and borne in clusters. Color white, beatifully flushed with pink.

Madame de Watteville--Mlso known as the Tulip Rose, on account of the beatutiful feathery shatlings of bright rose around the edge of ach petal. A strong, vigorous grower, with handsome foliage. Color white, shinded with salmon, outer petals feathered with bright rose ; very frigrant ; flowers lange and beautifnl slinpe,

Papa Gontier-A magnificent red Tea. It is a strong grower with fine healthy foliage; the buds ane large and long, with thick, broid petals of al dark camine crimson color, changing to a lighter shade in the open flower. An excellent winter blooming variety, and one of the best for out-loor plinting, opening up the flowers in beatiful shipe when grown in the open ground.

Perle des Jardins-A lreantiful straw color, sometimes deep canary; very large, full and of fine form; stiff shoots or stems and very free towering.

Pearl (Seeded from President, fertilizel with ('ontesse de serenye)-Beautiful pale flesh color, or creamy white, delicately tingecl with rosy blush; medium size, very full, perfeet form ; delight fully perfumed.

Reine Marie Henriette-flower large, full, of fine form ; (olor. beantiful cherry rewl, with a shade of violet; tlowers somewhat that, highly scenterl, and in color and form have some resemblanee to C'heshunt lIybricl ; an extrat fine climbing variety.

Sefrano-Fawn, straded with lose.

Sunset-Tawny slade of satfron and orange, very donble and hamdsome, and lias beantiful riels foliage; one of the best roses of recent introduction ; excellent for forcing.

The Bride-A lovely pure white tra rose of large size. Admirable for forcing as well ats for summer tlowering. The luds have more substance than Niphetos, ane full ant double and possess the grool illanterteristics of (atherine Mermet.

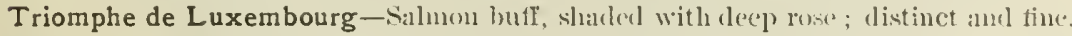

Yellow Tea-du old and popular rose; very fragrant ; straw color ; very fine bud.

\section{CHINA, OR BENGAL ROSES.}

These are very appropriate for becls on account of their clwarf habits of growth. They bloom all througl the Summer iu open ground, and mily be protected through the Winter in a pit or house.

Agrippina, or Cramoise Superior-Rich velvety rrinson.

Arch Duke Charles-liosy crimson, distinct ind fine,

Douglass-Rich velvet color; a fine, free blooner.

Daily, or Common-Light pink, a constant hlonner.

Eugene Beauharnais-Bright amalnuth ; distinct anxl jine.

Sanguinea-Deep crimson; a most profuse and constant bloomer ant free grower. 


\section{POLYANTHA ROSES.}

A new elass of lioses of dwarf labit, with small, very double fiowers, freely producer ; while they are perfectly hards, and most excellent for out-door planting, they are also fine for winter blooming.

Jean Drivon--The flowers of this variety are the largest of any of the Polyantha class, beiug nearly one-half larger than some athers. Color, pure white; growth busliy, fine for pot culture.

Max Singer (Climbiug Polyantha)-A very strong, rampant growing rose ; will be useful in the South for covering verandas and pillars; flowers in clusters like the dwarf varieties; color bright pink; not as free flowering as the rest of the class.

Mignonette-One of the most beautiful miniature Roses imaginable. The flowers are full and regular, perfectly double, borne in large clusters, often thirty to forty flowers each. Color elear pink changing to white, tinged with pale rose; a constant and profuse bloomer.

Miniature--One of the most beautiful miniature roses ; flowers quite small and of regu. lar form ; plant very dwarf, bnt vigorous and brancling; color white, slightly tinted with a peachy pink.

Paquerette--Pure white, about one inch iu diameter, flowering in panicles of from five to forty blooms ; full, prettily formed, reealling blossoms of the double flowering cherry. In flower continuously frou June to November.

Perle d'Or--Color of the buds beautiful nankeen yellow with vivid orange center ; each petal tipped with white, changing to buff-tinged rose in the open Hower; a splendid variety either for pot culture or bedding out.

\section{CLIMBING ROSES.}

These are admirably adapted for covering walls, trellises, old trees, unsiglitly buildings, ete. 'Tleir rapid growth, perfect hardiness, luxuriant foliage, immense elusters of beantiful flowers commend then at onee to every one.

Baltimore Belle-Fine white with blush center; very full and double.

Gem of the Prairie--A hybrid between the Queen of the Prairie and Madam Laffay. It is a strong and vigorous grower, similar in habit to the Queen, but the flowers are eonsiderably darker in eolor, besides being quite fragrant.

Greville, or Seven Sisters--Large elusters of bloom, shaded to dark red.

Mrs. Hovey-l'ale, delieate blush, beeoming almost white; resembles Baltimore Belle.

Queen of the Prairie-Bright lose eolor ; large, compact and globular ; a very profusc bloomer. One of the best.

Triumphant-Color, rose; farker than Baltimore Belle. Strong grower, free bloomer, a very exeellent sort. I lesirable addition to the list of Climbing lioses.

\section{MOSS ROSES.}

Etna--Bright crimsou, very double; superb.

Captain John Ingram--Dark velvety purple, full and tine.

Countess of Murinais-White, slightly tinged with flesh. The best white moss.

Crested-Rose ; beautiful and enious mossy fringed calyx. Finest of all for buds.

General Drouot-Deep erimson, rery mossy, a free bloomer ; dwarf habit; perpetual.

Glory of Mosses--Pale rose, very large, full and beautiful.

Luxembourg--Large, cupped, fine purplish erimson; a luxuriant grower and free bloomer.

Laneii-Rosy erimson, shaded witl purple, grows well, superb.

Madame Edward Ory-Reddish cumine, large and full. A very molerate grower; perpetual.

Perpetual White-Pure white, blooms in large chusters. 


\section{MOSS ROSES-rontiuned.}

Princess Adelaide-13lu:h, beconting quite pale: very double and well formel; the most vigerous grewere of all the Allosse's.

Salet-Clear rose rolor, very double, vigorous growh and abundant bloom : perpetual. Wm. Robb-Light crimson purple, large and double.

Unique-Pure white, large and full.

\section{SUMMER ROSES.}

Lureti-Fine, dink velvety purple; globular and double.

Harrison's Yellow-Doulle; bright yellow; very showy and fire.

Madame Hardy-White, large, full and double.

Madame Plantier-()ne of the finest pure white roses, bloomingr iu clnsters.

Persian Yellow--Deep golelen yellow; double and very finc.

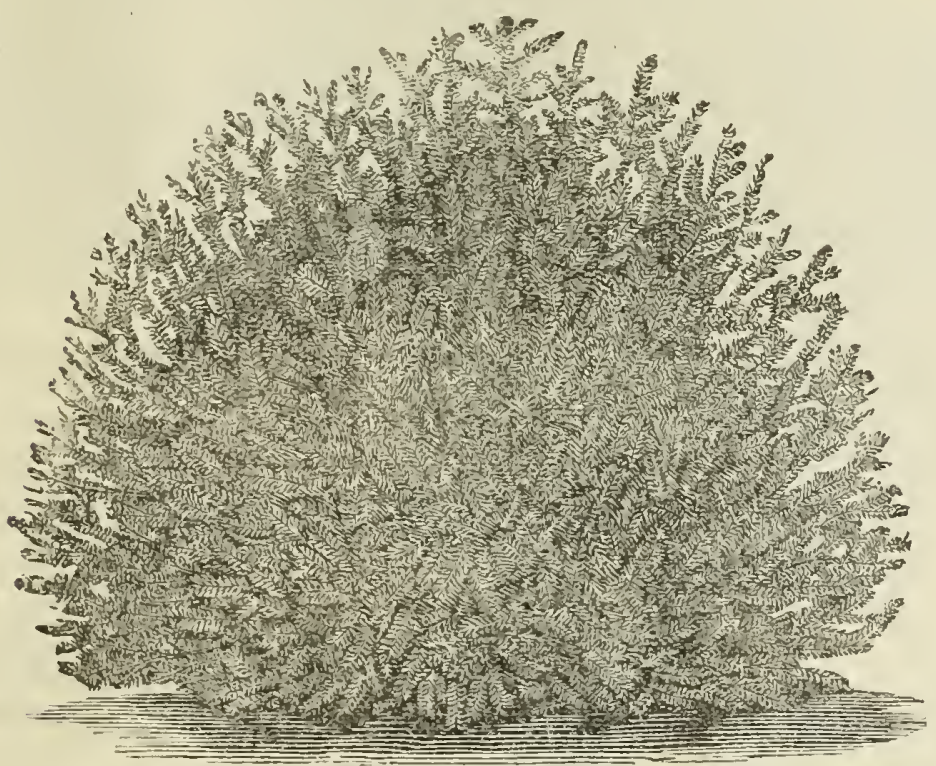

AREOR VIT.E-TOM THUML.

\section{EVERGREEN SHRUBS.}

Arbor Vitæ.

TOM TIILAB-Sinilar to the Heath-Leaved, but more desirable; remarkably" slow, compact labit ; valuable for plinting in cemetcries and small places, where linge trees are not admissable.

Ashberry (Mallonia).

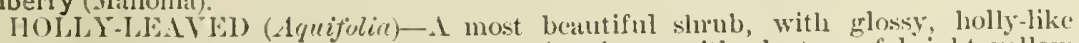
leaves, which change to brownish green in winter, witll clusters of bright yellow llowers in llay; very harely and makes a good hedge.

Box (13uxus).

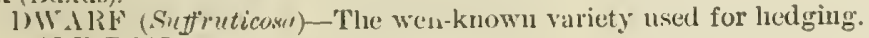

TRE.: BOX-Several sorts.

\section{Euonymus.}

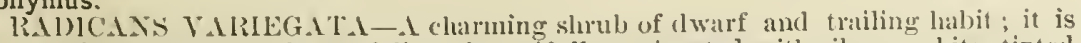
perfeetly hardy and hats folliage beautifully variegated witlo silvery white, tinted witl red in the llinter. Cinsurpassed for eilging. 


\section{Hedge Plants.}

To seeure a good hedge it is necessary to plant well. Dig a wide, deep trench, and work the soil thoroughly into the roots. Settle the ground firmly, so that eneh plant will be set as solidly as a post, then mulcl leavily with some coarse material for a distance of one or two feet on either side, according to the size of the plants. This is especially necessary witl Evergreens, and all exposure of the roots to the sun and air must be strictly avoided. Evergreens sliould not be planted in the Fall.

\section{DECIDUOUS HEDGE PLANTS.}

Honey Locust-Very harly, and the cheapest and best for defensive hedges.

Osage Orange-Highly esteemed at the West and South. Not hardy enough for the Northern States.

Japan Quince-Unquestionably the finest of all plants for an ornamental hedge. Grows very compactly, will submit to any amount of pruning, while the brilliant and showy scarlet flowers make it exceedingly attractive.

The following are also very desirable for ornamental hedging, description of which will be found under the proper leadings in this Catalogue:

$\begin{array}{lrr}\text { Purple Berberry, } & \text { Roses, } & \text { Altheas, } \\ \text { Spireas, } & \text { Tartarian Honeysuckle, } & \text { Dwarf Box, for edging. }\end{array}$

\section{Pheonies.}

A splendid class of slurubs, flowering in all shades, from red and lilac to white, with blooms from four to eight inches in diameter. Nany of them are very double, and lave a delicate and refreshing fragranee; they are easily cultivated and require but little protection.

\section{TREE PAEONIES.}

Banksii-Rosy blush, with purplish eenter; double and fine.

\section{HERBACEOUS PAEONIES.}

These are very beautiful, showy, and easily cultivated plants, blooming from the beginning of May to the end of July. They should have a place in every garden. A selection will give a eontinuous bloom for three months. We offer the best sorts, varying from pure white, straw color, salmon, flesh color and blush to lilac and deep rose.

\section{Evergreen Hedge Plants.}

Am. Arbor Vitæ, Mahonia Aquifolia,
Norway Spruce, Siberian Arbor Vitæ,
Tom Thumb Arbor Vitæ, for borders, Hemlock, 


\section{MISGEI, H NEDUS}

\section{BORDER AND HOUSE PLANTS}

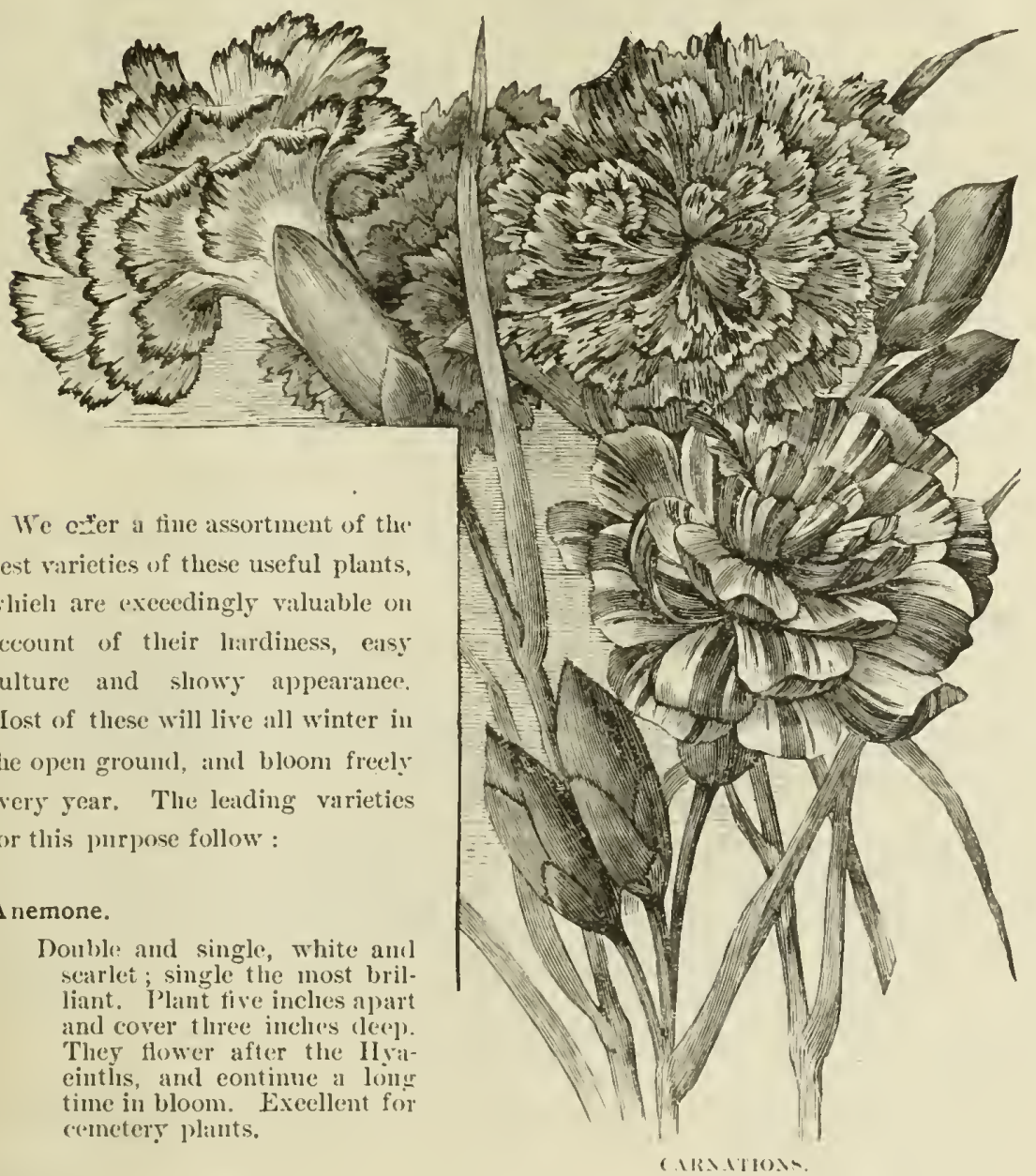

Bell Flower ((':แ1):ar:ula).

Large, slowy, bell sh iped flowers of pure white. blue and purple. June to lugust. Baptisia (False Indigo).

Itandsome spike of blue. Japiu-straped tlowers; in inne and July.

\section{Carnations.}

White, earmine, rosy pink and striped ; very lumbtinl anul frampunt, rontinuiner in flower a long time. Plant in pots in Fall, amel grow in conservatory or pirrlor window. One of the best homes plants. 


\section{Chrysanthemums.}

The prettiest of the late Antumn and cany Winter flewering plants. In November and December there is nothing that will make such a cheerful display. Plant in pots and place them in the louse wherc they will have the sun. The prevailing colors are white, yellow and red, the red being the least interesting.

\section{Columbine (Aquilegia)}

Well-known flowers, hanging from rather tall stems, about two feet ligh; various colors.

Daisy (Bellis).

Red, white and pink, double and quilled.

\section{Dahlias.}

The Dahlia is the grandest Autumn flower we have. Nothing is its equal in any respect in September and October. It is in its glory when everything else is faded or fading, and surrenders only to the Frost King. Put Dahlia tubers in the ground when the season bccomes warm, covering the neck some three inches. If many shoots start thin them out. After flowering, and before hard frosts, take up the plants, remove the tops, dry the bulbs a little, and put in the ccllar until Spring: when they can be dividerl and replanted. Look at them occasionally to see that they are not shriveling from too dry an atmosphere, nor starting the eje too early in consequence of too much moisture and warmth. The Dahlia is divided into three distinct classes-the ordinary Show Dohlia; the Doarf or Bedding Dahlia, making a thiek, compact bush only eighteen inches in licight, but with thowers of full size; and the Pompon or Bouquet, with small, very perfect flowers, only from one to two inches in diameter, while the plant is of nearly the common size. As the Dahlia is a Fall flower, therc is no need of planting before the midrlle of May, or even later. Many varieties can be supplied.

\section{Dicentra Spectabilis, or Dielytra (Bleeding Heart).}

I beautful, harrly border plant, with brilliant, rosy, heart-shaped flowers, hanging in great profusion from a gracefulls curved stem. May and June.

\section{Eulalia.}

JAPONICA - A lardy perennial rrom Japan, with long narrow leaves striped with green and white, throwing up stalks four to six feet high, terminating with a cluster of flower spikes, on which the individual flowers are arranged ; the flowers are surrounded with long, silky threads, which, when fully ripe, or when placed in a warm room, expand, giving the whole liead a most graceful and beautiful appearance, not unlike that of an ostrich feather curlerl. These dried flowers are valuable as parlor ornaments, as they retain their beanty a long time.

JAPONICA ZEBRINA-This is one of the most striking and distinct plants in cultivation. Unlike most plants with variegated folinge, the striping or marking is across the leaves instead of longitudinally, the leaves being striperl every two or thrce inches by a band of Jellow one-half inch wirle. Late in the fall it is covered with tlower spikes that resemblc ostrich plumes in shape, which, when cut and dried, make handsome ornaments for the lionse in winter. It is perfectly hardy, and when once planted will increase in beauty from year to year. Should be in cvers collection.

\section{Feverfew (Pyrethirnm).}

Fine, double Aster-like flowers in profusion. Very desirable; white, blnsh, rose, scarlet and crimson.

Forget-me-not (Myosotis).

Beautiful and popular small plants; white, blue and yellow. May to August.

Fox Glove (Digitalis).

Long lell-shaped flowers, on stems three to four feet high; white and red ; very showy. July to Septcinber.

Fraxinella (Dictammus).

I strongly perfumed plant, with pretty spikes of white and reddish pmrple flowers in June. 
Hollyhock.

There ane very few phants in the workd so grand, and yet so perfect and delicate as the Iollyliock. Its Hower's ale quite as domble, and almost as pure and perfect as those of the Camellia, and when we remenuber that they mass around a colmm from three to five feet in lecight, we ret some jeleid of their beauty. Siend sown in the spring produce plints that will biom the second summer. Plants set out in the Spring will tlower abont midsummor, ant? for several y("als if not allower to bloom too freely the first yenr. We lave excellent, healthy young plants grown from seed, that if planted in the spring will flower the first Simmmer, and nsually for two or three simmers after. The colors are nicely assorterl, so that almosit every color, from white to purple, may be expected.

\section{Milfoil (Aclilleiı),}

law growing plants, with abundant, showy flowers; white and red. June. to Ang.

\section{Perennial Larkspur.}

The P'oremial laukispur, like their relatives, the Annuals, commonly called Iarkspurs, are vahuble plants, and in no other way can we get such a grand and constant display of bhe flowers. Formosum is a most brilliant dark bhe, by all odds the tinest blne flower known among our hardy plants. The Chinese are generally of lighter shades, from lavender to deep blue.

\section{Perennial Phlox.}

The thowers of the Perennial I'hlox are immense masses of bloom from the purest white to crimson. They grow to a lieight of two feet or more and are perfectly luardy.

\section{SUMMER AND AUTUMN FLOWERING BULBS,}

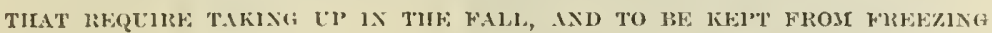

\section{Amaryllis.}

FORMIOSISSIMA (Jacobean Lily)-Flower's large, deep red.

JOIIXSONIA_Dull brick red, with a white star center.

\section{Boussingaultia.}

B.LSILOIDLS (Madeira Vine)-An oll, well-known climber ; a rapid grower, with thick fleshy leaves and white flowers, grand for trailing over a porch, or a window, or in any place where you clesire a beantiful green.

\section{Gladioıs.}

These are among the most showy and brilliant of all bulbons plants. Fature is nowhere more lavish of her paint than upon the flowers of the Gladiolus. They should be planted out of cloors in the spring-never in the Fall, as the bulbs will not stand freezing. - They are, however, excellent for window culture, planted in vases, eitler singly or in groups.

\section{Tigridius.}

SIIELL FLOWER-One of ou favorite Summer-flowering bulbs, of the casiest culture, displaying their gorgeous, tulip-like flowers of orange and scarlet, daily from July to Octoher.

CONCIIFHORA-TRIlow.

PAVOXIL-Red.

\section{Tuberose.}

1)(OLLE WIITl: I.VI SINGLE-Flowers very fragrant, Stems from three to four fect. Late. Ant 11 min.

PISARL-Its value over the common variety consists in its flowers being nearly louble in size; inbricater like a rose, and its dwarf habit, growing only eighteen inches to two feet. Tlye fraglance and color same as common sort.

Vallotta.

P'LRI'LRLA-A very beantiful and showy Fall flowering, bullous rooted plant: the flowers are borne on stems growing about twelve inches higli, and consists of tive or six . Amaryllis-like flowers of a brilliant liomun purple color. 


\section{FLOWERING BULBS TO BE PLANTED IN THE FALL.}

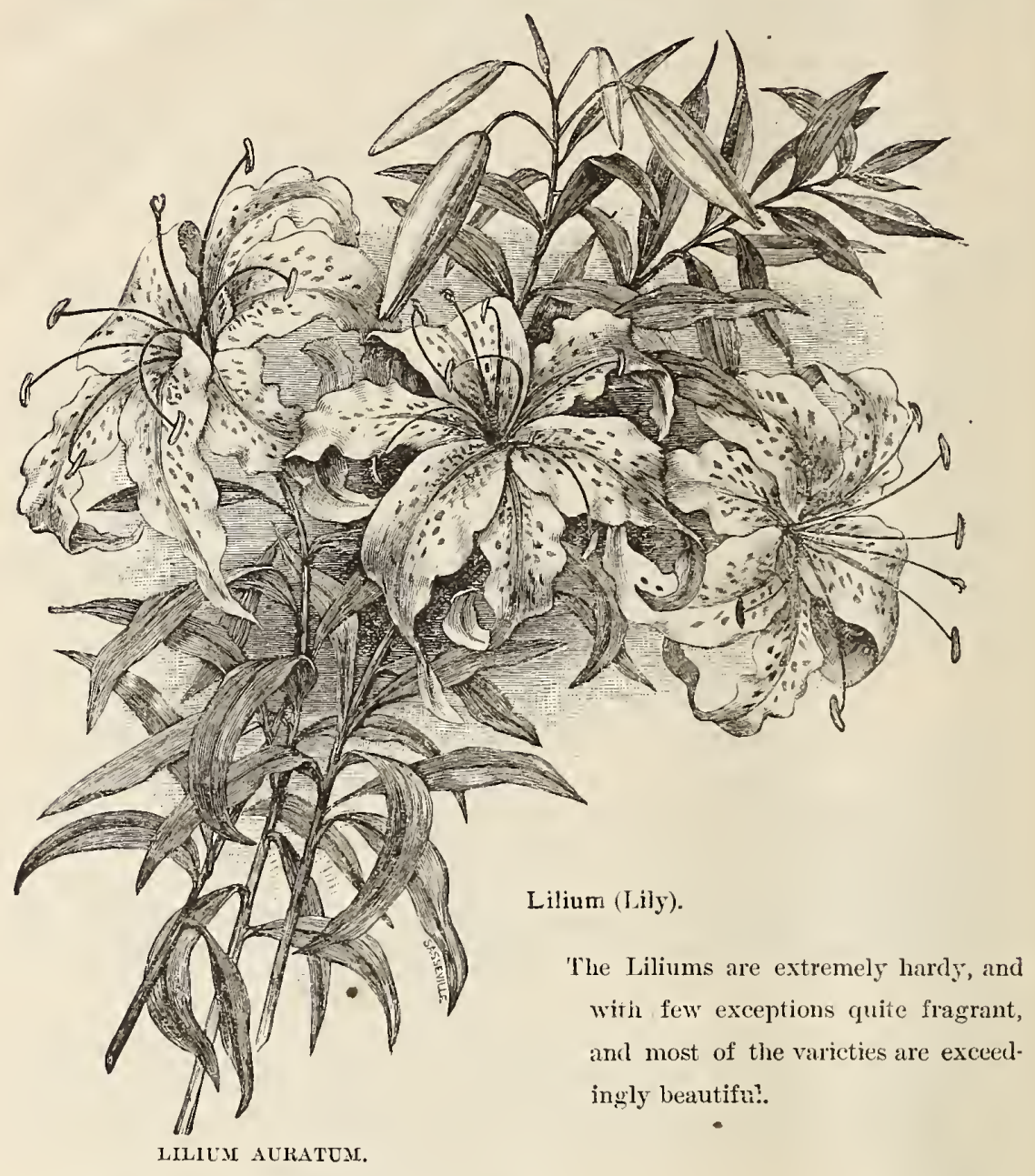

ACRATL2I-Gohl banded Lily of Japan.

CANDIDUM-Common white.

CANDIDLI, il, pl.-Dhouble white tiowering.

LANCIFOLILA ALBLN-White Japan.

J.ANCIFOLIUH ROSEUM-liose spotted.

LANCIFOLIUI RLIBLLI-Rerl spotted.

TIGRINUM, 11. pl. (Double Tiger Lily)-Bright orange scarlet with dark spots.

IANCIFOLILM PUNCTATUM-Pink and white.

TENUFOLIUM-One of the earliest flowering Lilies; foliage slender and flowers brilliant searlet. 'Th's is a bitte beinty.

UMHELTATLZI-Viviı orange. . 
Lily of the Valley.

The Lily of the Valley is as hardy as any plant can possibly be, and when nlanted in the open groninl will increase pretty rapidly. For the house we have what are called "pips," young roots with flowering stems, that will bloom in a few weeks after planting, and will flower well in baskets of damp moss, or pottel. Pips for winter flowering in the homse, we can send out in December, as they will not suffer injury from frost. For the garden we ean slip either in the Spring or Autnunn.

\section{Narcissus.}

\section{GARDFN VARIETIES.}

Admirably adapted for garden decoration in eurly Spring. They are casily cultivated; hardy ; very showy and frag grant.

\section{SINGLE VARIETIFS}

BILFLORUS-White with yeliow enp.

NANAS MAJOR.

POETICUS-White, with red·cup.

TRILOBLS.

DOUBLE YARIETIES.

ALBA PLENO ODORATA-White and fragrant.

INCOMPARABLE-Yellow and orange.

ORANGE PIIENIX-Orange and lemon.

VAN SION (Double Diffodlil)-Yellow.

Crocus-In various colors.

\section{Colchicum Autumnale.}

\section{Frittiliaria Imperialis.}

CROWX IMPERIAL-Very showy plants; are quite hardy anr? wheil the bnlbs are once planted they need no further culture. Plant five inehes r $r e n$, one foot apart.

\section{AURORA, CROWN ON CROWN, WILLIAII REX.}

\section{Calanthus.}

SNOW DliOP-This, the earliest of spring flowering lubls, is universally admiserl for its elegant snow-white drooping blossoms. 


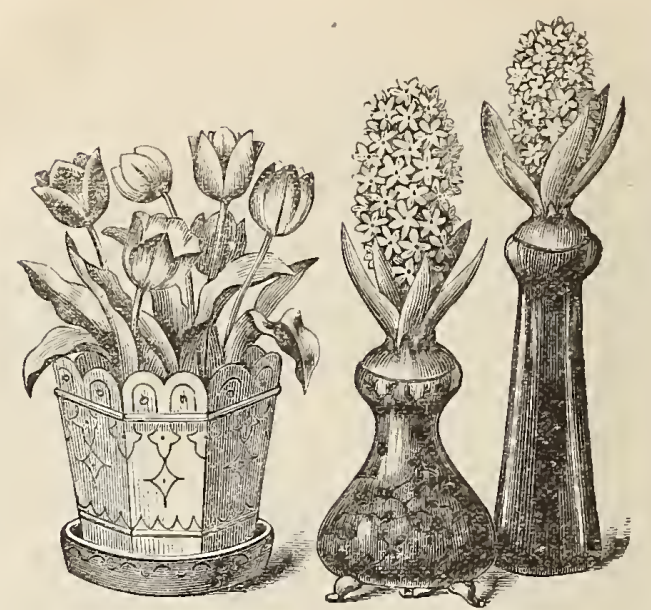

MYACIN'IIS flowering in water and TULIPs in earth.

\section{Hyacinths.}

Among the bulbs used for Winter flowers, the Hyacinth stands foremost on the list. Two nnethods are employed in flowering the Hyaeinth in Winter, one in glasses filled with water, the other in pots or boxes of soil. Double and single varieties ean be supplied.

\section{Jonquils.}

Pretty varieties of the Nareissus, having a very agreeable fragranee; adapted to either pots.or out-door culture. The bulbs being small, six or eight may be put in a six-incle pot.

\section{Polyanthus Narcissus.}

Beantiful early Spring flowers, produced in large elusters of white and yellow. Quite fragrant, making them very valuable as parlor or eonservative ornaments.

\section{Tulips.}

Owing to the late Spring frost, bedding plants eannot safely be planted before the early Spring flowering bulbs are through blooming. Without these bulbs, for one or two months of beautiful Spring weather, our gardens would present a bare appearance, We know of nothing that for the amount of money invested will give a more gorgeous show during early Spring, and there is nothing more easily grown than the Tulip. They thrive well in almost any soil. Should be planted during October and November.

\section{DOUBLE. EARLY FLOWERING NAMED VARIETIES. \\ SINGLE. EARLY FLOWERING NAMED VARIETIES.}

DUC VAN THOL. Single red, early.

DUC VAN THOL. Double red.

DUC VAN THOL. Single white.

DUC VAN THOL. Single yellow.

PARROTS' named varieties.

TOLRNESOL. Orange and red, double, earty. 


\section{Correet Names of Fruits.}

The American Pomological Society very wisely recommencls the shortening or abbreviation of the names now in use amongst the Nurserymen and Fruit-Growers, and, in accordance with this expressed desire, which was umaninously adopted by the. Isociation of American Nurscrymen at their meeting in June, 1889, at (hicago, we now give the names as in use, and the change as recommended by the Ameriean Pomological socicty. More will follow, from time to time, which will be annommerel and arlopted in subsequent editions of this ratalogue. We insert them here that patroms may become. acyuainted with the rhange: AH'ILS.

XAME IREJCTEI:

American Golden Pippin...

American Summer Pearman ... _... . . . . . . .

Carolina Red Jume.

C'henango Strawberry.

Danver's Winter Swret

Ducliess of Oldenburg

IIulubardston Nonsucli

Jewett's Fine Red

Kentucky Red Streak.

King of Tomplins (ounty .

Large Yellow Bough

Pyle's Red Winter.

Tewksherry Wintel lilush

Twenty Oinee Appla.

Early Purple Guigno

Empress Eugcnie

Knight's Early IBlacli

La Versaillaiss'

Smitls's Improved ...

Woolward's IVlitesnith

IIartfori Prolific

Amselen's June . . -

Cole's Early Red

Einly Bcatrice.

Early lonise. .

Eirly Rivers

Harker's Seedling

Ward's Laite Free.

Beurre Bose.

Beurre Clairgeau

Beurre d'Anjou...

Beurve Diel.

Beurre Giffard ....

Beurre Hardy.....

Beurre Superfin ..

Doyenne Boussork

Doyeme d'Ete

Duchesse d'Angouleme

Duchesse de Borlenux

Josephene de Malines.

Lonise Bonne de Jersey

Petite Marguerite

Vicar of Wakeficld

Ror's Seedling.

Cumberland Triunjolı

Miner's Grent Prolitie.

President Wilda.

Wilson's $\Lambda$ Ibany

('IlERासासे

(1)BRINTS

(IRAPEK

H.AC"IIY:

QTINCES.
NIVIF ADOPTED. Amoricun Golden

- Ameriean Summer.

('aloline June.

('lichango).

1)amrers sivert.

Oldenlourer

Hublardston.

Jewott's Red.

. . . . Kentucky Red.

... Toupkius King.

. . . Swert Bough.

. . . Pyle's Winter.

Tewsherry Wiuter.

.... Twenty (Hunec.

Early Purple.

Engenie.

Kuight's Early.

(IOONEBERIRIEN.

Versaillaise.

Sinitl's.

... . Whitesmitl.

7. - 2. -

Hartforel.

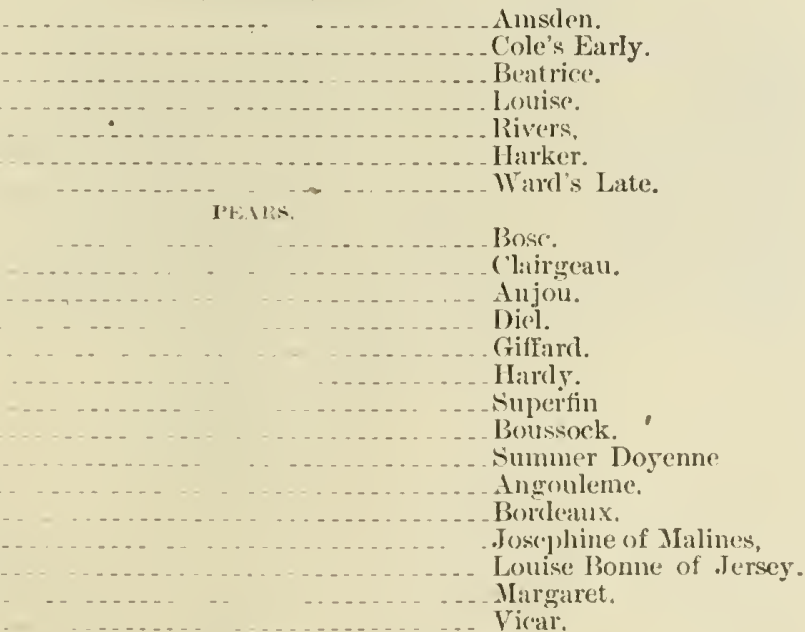

STRAW BERIRIFS.

Reil.

Cumberland.

Miner's Prolifie:

Wilder.

Wilson. 


\section{INDFX.}

\section{FRUITS.}

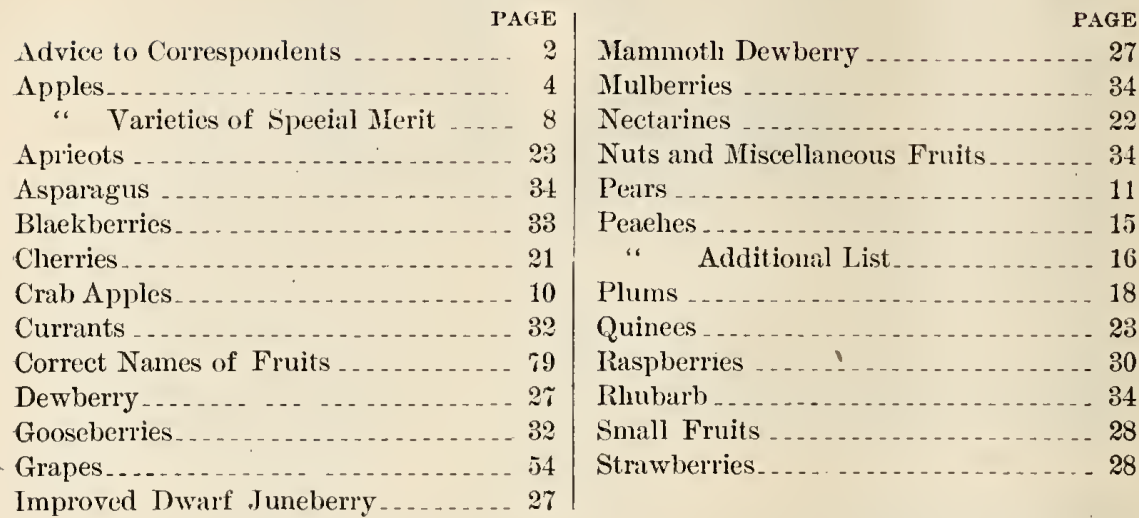

\section{ORNAMENTALS.}

\begin{tabular}{|c|c|}
\hline Azaleas, Hardy Ghent & Evergreen Shrubs. \\
\hline Camellia _ _ _ . . . . . . & General Remarks . \\
\hline Clematis .......... & Hedge Plants....... \\
\hline Climbing Shrubs . . . . . . . & Miseellaneous Border and House Plants \\
\hline Deeiduous Shrubs ........ & I'ronies \\
\hline Deciduous Trees 36 & Rliododendrons. \\
\hline Evergreens & Rosies \\
\hline Evergreen IJedge Plants . . . . . . . . . & Wreeping Deeiduous Trees... \\
\hline
\end{tabular}



